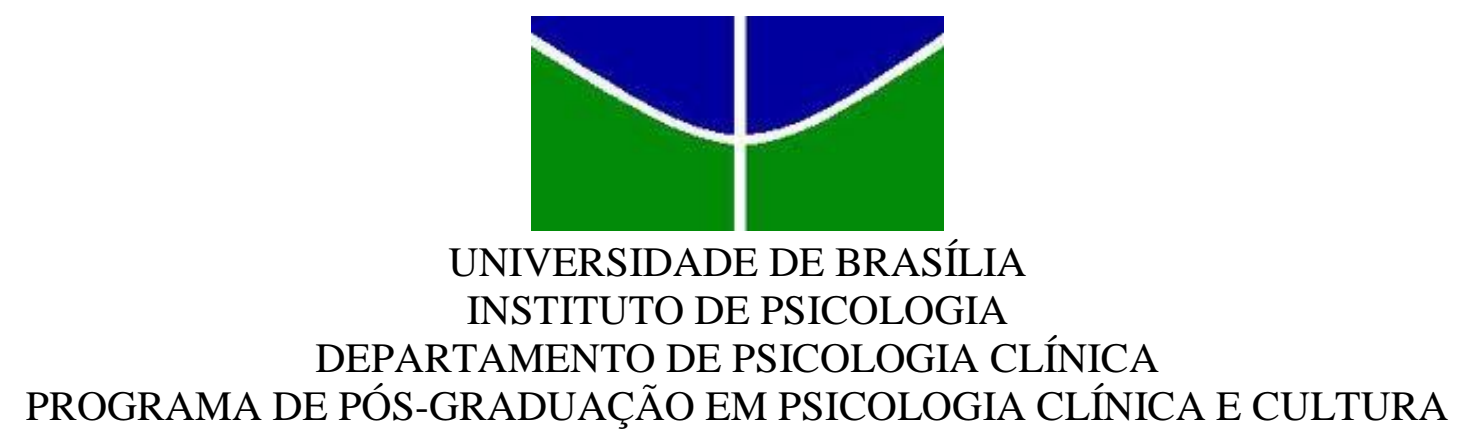

JULIANY GONÇALVES GUIMARÃES DE AGUIAR

MITOS E CRENÇAS SOBRE O SUICÍDIO: VISÃO DE PROFISSIONAIS DE SEGURANÇA 


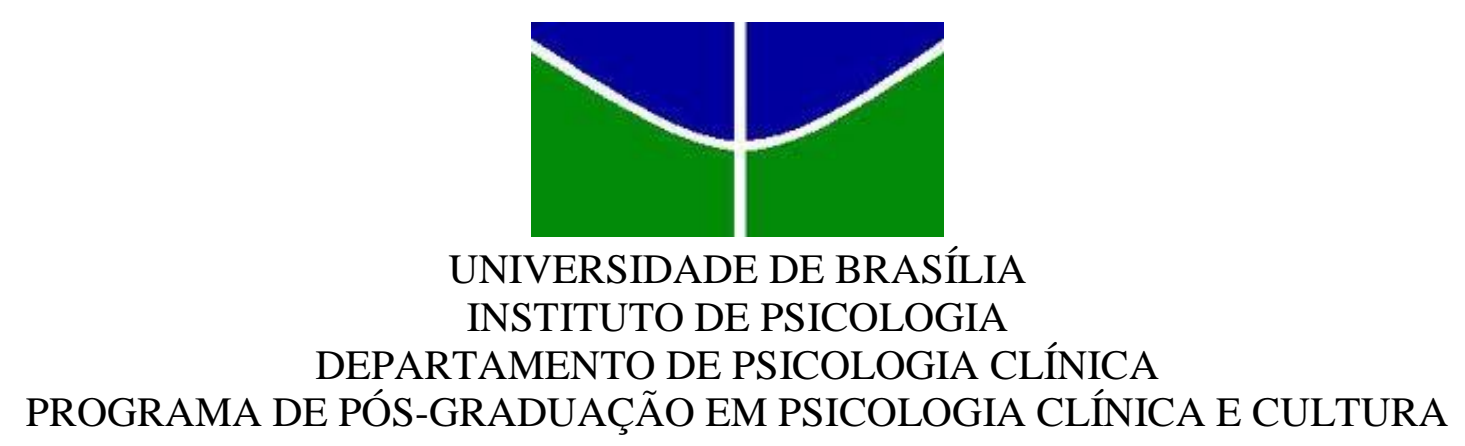

\section{MITOS E CRENÇAS SOBRE O SUICÍDIO: VISÃO DE PROFISSIONAIS DE SEGURANÇA}

Tese de doutorado relacionada à linha de pesquisa Saúde Mental e Cultura, vinculada ao Programa de Pós-Graduação em Psicologia Clínica e Cultura, do Instituto de Psicologia da Universidade de Brasília, apresentada à banca como requisito parcial para a obtenção do título de Doutora em Psicologia Clínica e Cultura.

Orientadora: Prof. ${ }^{a}$ Dr. $^{\text {a }}$ Eliane Maria Fleury Seidl.

Brasília-DF

Março de 2017 
Aguiar, Juliany Gonçalves Guimaraes de

AAG282 MITOS E CRENÇAS SOBRE O SUICÍDIO: VISÃO DE

PROFISSIONAIS DE SEGURANÇA / Juliany Gonçalves Guimaraes de Aguiar; orientador Eliane Maria Fleury Seidl. -- Brasília, 2017.

$135 \mathrm{p}$.

Tese (Doutorado - Doutorado em Psicologia Clínica e Cultura) -Universidade de Brasília, 2017.

1. suicídio. 2. mitos e crenças. 3. valores organizacionais e pessoais. 4 . profissionais da polícia militar e do corpo de bombeiros. I. Seidl, Eliane 


\section{MITOS E CRENÇAS SOBRE O SUICÍDIO: VISÃO DE PROFISSIONAIS DE SEGURANÇA}

Banca Examinadora:

Data da avaliação: 09/03/2017

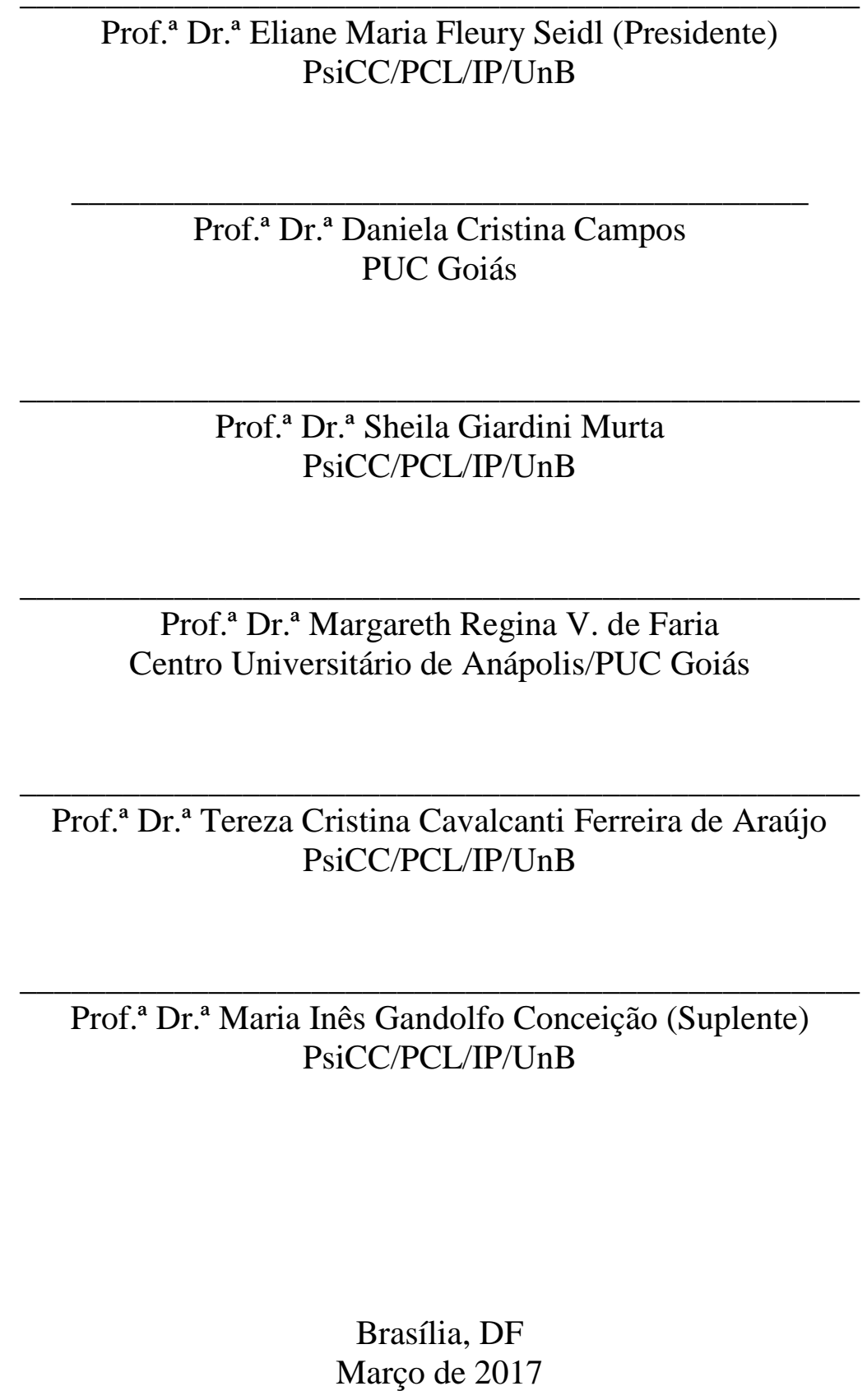


A Deus, por ter cuidado da minha família na minha ausência e por ter me protegido neste percurso. 


\section{Agradecimentos}

A Deus, pela oportunidade de viver, por ter me dado coragem, saúde e ter me permitido concluir esta formação.

Aos meus pais e, em especial, à minha mãe, Luzia, e à irmã Elba, por terem cuidado dos meus filhos na minha ausência. Agradeço a todos da minha família, pelo apoio, pelo carinho e pela dedicação.

Ao meu marido, Jair, pelo apoio nas viagens, e, principalmente, pelo suporte afetivo e social.

Obrigada a minha mais do que mestre, a amiga querida Dr. ${ }^{a}$ Ana Raquel Rosas Torres.

Agradeço à professora Dr. ${ }^{a}$ Eliane Seidl, pelo acolhimento em momento tão importante, por todos os ensinamentos, pelo carinho, pelas orientações e pelo apoio durante o último ano.

Aos meus amigos, que entenderam minhas ausências nos momentos de lazer. Luciene Falcão, Márcia Alencar, Tereza Cristina e Ivone Félix, obrigada pela motivação, pelo carinho e pelo apoio nos momentos de dificuldade.

À Thalita Martignoni, parceira e incentivadora.

À Thais Renata Carneiro, pela companhia nas viagens Goiânia a Brasília: sem força coletiva, não conseguiríamos.

Aos professores doutores Maria Inês Gandolfo Conceição, Margareth Regina, Sheila Murta, Tereza Cristina C. F. de Araújo e Daniela Campos, por suas importantes contribuições para este trabalho.

À PUC-Goiás, pelo incentivo e por compreender a minha ausência. 
Em especial, aos participantes do estudo um - estudantes dos cursos de Medicina, Psicologia e Enfermagem - e do estudo dois - Polícia Militar e Corpo de Bombeiros do Estado de Goiás. 
“A obsessão pelo suicídio é própria de quem não pode viver, nem morrer, e cuja atenção nunca se afasta dessa dupla impossibilidade”. 
O suicídio tem se tornado cada vez mais foco de preocupação dos estudiosos, pois os casos têm aumentado significativamente, inclusive no Brasil. Apesar de já existirem estudos sobre o tema, ainda há muitos mitos e crenças que circundam essa temática. Diante desses fatos, buscou-se entender melhor a percepção de profissionais que atendem urgências de vítimas de Tentativa de Autoextermínio (TAE) sobre o suicídio, levantando, ainda, os valores pessoais e organizacionais que podem estar associados a esses mitos e crenças. A presente tese está dividida em dois estudos, com os seguintes objetivos: (1) proceder à análise fatorial exploratória da Escala de Mitos e Crenças sobre o Suicídio (EMCS); (2) identificar mitos e crenças de militares (da Polícia Militar - PM e do Corpo de Bombeiros Militar - CBM) que atendem emergências, bem como investigar associações entre mitos e crenças com valores pessoais e organizacionais. No primeiro estudo, a EMCS foi utilizada de forma autoaplicada, em 493 estudantes da área de saúde. A análise fatorial exploratória apontou que ela é válida e fidedigna para proceder a esta investigação, sendo unifatorial e com 32 itens. Do estudo 2, participaram 464 profissionais militares (PM e CBM). Os instrumentos utilizados foram a EMCS, Questionário Psicossocial de Valores, a Escala de Valores Organizacionais, Questionário sociodemográfico e duas questões abertas sobre aspectos facilitadores e dificultadores no atendimento ao suicídio. Para o tratamento estatístico, foi usado o Statistical Package for the Social Sciences, com análises descritivas e inferenciais. Para a análise qualitativa, foram realizadas análise semântica e de juízes. Os resultados apontaram que os militares obtiveram, na EMCS, escore médio igual a 24,85 $(\mathrm{DP}=3,30)$, indicativo de que tinham algum nível de conhecimento sobre essa temática. Os profissionais da área de segurança pública do sexo feminino, com menos de 38 anos de idade, com ensino superior ou mais e no cargo de oficiais possuíam mais informações relativas ao suicídio compatíveis com a literatura científica. Dois fatores da escala de Valores Pessoais (QVP-24) foram preditores de mitos e crenças sobre o suicídio: o fator hedonismo/materialismo predisse negativamente e o bem-estar social foi preditor positivo. No entanto, a reduzida variância explicada observada sugere que variáveis não pesquisadas neste estudo devem ter influência sobre os mitos e crenças. Nas questões abertas, a análise qualitativa indicou que as maiores dificuldades no atendimento à vítima são lidar com a abordagem (convencer a não praticar o ato), com fatores sociais (desespero da família) e fatores operacionais e emocionais (falta de treinamento e controle emocional do militar). Já os fatores que facilitam são: a abordagem (manter diálogo, ouvir, negociar), fatores sociais (ter apoio de conhecidos e/ou familiares) e aspectos operacionais (ter equipe bem treinada). Considera-se, com base nessas categorias, que, dependendo dos valores pessoais - por exemplo, religiosos ou aspectos como falta de controle emocional do profissional ou de treinamento técnico específico - pode haver atitudes que resultam em atendimento ineficaz. Tomados em conjunto, os resultados permitem ampliar o conhecimento sobre mitos, crenças e valores dos militares, que, por sua vez, podem influenciar na compreensão do fenômeno suicídio, de forma a contribuir para o melhor atendimento de pessoas que atentam contra a própria vida. Ademais, o estudo poderá promover reflexões e ações mais efetivas nos treinamentos de urgências, melhorando os indicadores com atendimentos mais humanizados e eficientes.

Palavras-chave: Suicídio. Mitos e crenças. Valores organizacionais e pessoais. Profissionais da Polícia Militar e do Corpo de Bombeiros. 


\begin{abstract}
Suicide has increasingly become an object of concern among scholars of the field, with suicide cases becoming significantly higher and higher in many countries, including Brazil. In spite of the already existing studies, there are still many misconceptions regarding suicide. Given the aforementioned facts, this study aimed to better understand how health professionals taking care of urgent victims of self-extermination attempts perceive the idea of suicide, taking into account the personal and organizational values which might be associated with the myths and beliefs they hold. This doctoral dissertation is divided into two studies, which aimed to (1) carry out the exploratory factorial analysis of the Scale of Myths and Beliefs about Suicide (EMCS, in Portuguese) and (2) identify myths and beliefs held by military officers (namely military police officers and fire brigade members) answering emergency calls, as well as investigate how myths and beliefs intertwine with their personal and organizational values. In the first study, the EMCS was self-applied in 493 students majoring in different fields of study in health. The exploratory factorial analysis pointed out that the EMCS is valid and trustworthy to proceed to the investigation of myths and beliefs, being unifactorial and having 32 items. In the second study, 464 military professionals (police and fire brigade) were involved. The research instruments used were the EMCS, a Psychosocial Questionnaire of Values, a Scale of Organizational Values, a sociodemographic questionnaire, and two open questions about which aspects would make answering to suicide emergencies easier or harder. For the statistical treatment of data, the Statistical Package for the Social Sciences was used, with inferential and descriptive analyses. For the qualitative analysis, a semantic analysis was held, as well as another analysis held by experts. The results pointed out that the military officers obtained an average score of 24,85 (DP =3,30) in the EMCS, which indicates that the participants have some level of knowledge about suicide. The female security professionals aged less than 38, holding a bachelor's degree or higher and in higher positions showed knowledge compatible to that of scientific literature. Two factors of the Scale of Personal Values (QVP-24, in Portuguese) were capable of predicting myths and beliefs about suicide: the hedonism/materialism factor was a negative predictor, whereas the social welfare factor was a positive one. Nonetheless, the reduced observed explanatory variable suggests that variables which were not taken into account in this study might exert some influence on their myths and beliefs. In the open questions, the qualitative analysis indicated that the biggest difficulties in answering emergency suicide calls are convincing the individual to give up on self extermination (as far as approach is concerned), the despair of the family (as far as social factors are concerned), and the officer's lack of previous training and emotional control (as far as operational and emotional factors are concerned). The factors which make operations easier are keeping a dialog, listening and negotiating (as far as approach is concerned); the support of family and friends (as far as social factors are concerned); and a well-trained team control (as far as operational and emotional factors are concerned). Based on these categories, it can be considered that personal values, such as religion, as well as other aspects such as the officer's lack of emotional control or specific training, might lead to ineffective assistance. As a whole, the results provide a deeper understanding of the myths, beliefs and values that military officers hold, which might in turn influence how they see the suicide phenomenon. Understanding this may lead to better assistance to people attempting at taking their own lives. Furthermore, the study may foster reflection and more effective
\end{abstract}


action during officers' previous emergency training, thus improving indicators with more human, effective assistance.

Keywords: Suicide. Myths and beliefs. Organizational and personal values. Military Police and Fire Brigade Professionals. 


\section{Lista de abreviaturas e siglas}

ACP análise dos componentes principais

AFE principal axis factoring

CBM Corpo de Bombeiros Militar

EMCS Escala de Mitos e Crenças sobre o Suicídio

EVO Escala de Valores Organizacionais

Ibaco Instrumento Brasileiro para Avaliação de Cultura Organizacional

OMS Organização Mundial de Saúde

PM Polícia Militar

POP Procedimento Operacional Padrão

PUC-Goiás Pontifícia Universidade Católica de Goiás

Samu Serviço de Atendimento Móvel de Urgência

SPSS Statistical Package for the Social Sciences

TAE Tentativa de Autoextermínio

TCLE Termo de Consentimento Livre e Esclarecido

VO Valores organizacionais 


\section{Lista de figuras}

Figura 1 - Estrutura Bidimensional dos Tipos Motivacionais ........................... 34

Figura 2 - Gráfico Representativo dos Autovalores do Scree Plot para os Dados da Escala de Mitos e Crenças sobre Suicídio, Mostrando o Ponto que Separa os Fatores Triviais dos Não Triviais ..................... 45

Figura 3 - Cálculo da Amostra Pesquisada neste Estudo .................................. 50

Figura 4 - Critérios de Correção dos Itens da Escala de Mitos e Crenças sobre o Suicídio para Profissionais de Segurança, de acordo com o Gabarito de Acertos e Erros nas Respostas

Figura 5 - Gráfico Representativo dos Autovalores do Scree Plot para os Dados da EVO, Mostrando o Ponto que Separa os Fatores Triviais dos Não Triviais 
Tabela 1 - Metas Motivacionais

Tabela 2 - Cargas Fatoriais, Variância Explicada e Fidedignidade da Escala de Mitos e Crenças sobre o Suicídio ................................................... 46

Tabela 3 - $\quad$ Itens da Escala de Mitos e Crenças sobre Suicídio, após Validação. 47

Tabela 4 - Distribuição das Cargas Fatoriais dos Itens da Escala de Valores Pessoais, conforme os Quatro fatores Identificados na Amostra de Militares.

Tabela 5 - Distribuição das Cargas Fatoriais dos Itens da Escala de Valores Organizacionais

Tabela 6 - Análise Descritiva do Número de Acertos (escore médio) Relativo à EMCS

Tabela 7 - Médias, Desvios-padrão e Valores do Teste T a partir dos Escores na EMCS em Relação a Sexo, Idade, Corporação, Formação e Cargo

Tabela 8 - Médias, Desvios-padrão e Valores da Anova a partir dos Escores da EMCS em Relação à Religião e à Situação Conjugal .................. 65

Tabela 9 - $\quad$ Porcentagem de Acertos e Erros na ECMS ..................................... 66

Tabela 10 - Análise Descritiva das Variáveis QVP-24 (N=464) ...................... 68

Tabela 11 - Correlação entre Escore da EMCS e Valores Pessoais...................... 69

Tabela 12 - Resultados da Regressão Linear Múltipla (stepwise) Aplicada à Análise dos Fatores Preditivos do Acerto das Respostas Relativas à EMCS em Relação aos Valores Pessoais 70

Tabela 13 - Análise Descritiva das Variáveis EVO (N=464) ............................ 70

Tabela 14 - Correlação entre o Total de Acertos na Escala EMCS com os Fatores de Valores Organizacionais

Tabela 15 - Resultados da Regressão Linear Múltipla (enter) Aplicada à Análise dos Fatores Preditivos do Acerto das Respostas Relativas à EMCS em Relação aos Valores Organizacionais

Tabela 16 - Categorias e Subcategorias sobre Dificuldades no Atendimento a Pessoas em Tentativa de Autoextermínio e/ou Suicídio, Segundo os Participantes 
Tabela 17 - Categorias e Subcategorias Sobre Facilidades no Atendimento a Pessoas em Tentativa de Autoextermínio e/ou Suicídio, Segundo os Participantes 
1.3 Profissionais de segurança no atendimento a tentativas de autoextermínio .. 12

Capítulo 2 - Valores Pessoais e Organizacionais em Instituições Militares

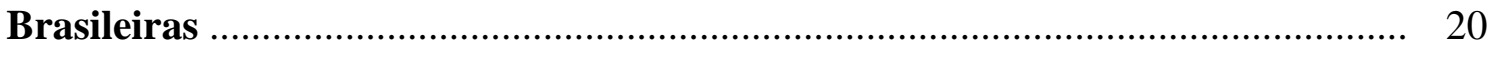

2.1 Raízes do militarismo brasileiro …........................................................... 20

2.2 Cultura, valores pessoais e organizacionais .............................................. 24

Capítulo 3 - Justificativa e Objetivos do Estudo .............................................. 37

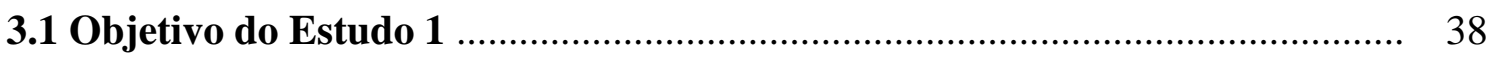

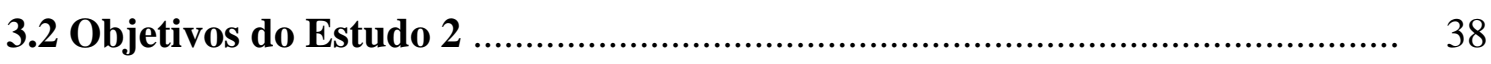

Capítulo 4 - Estudo 1 - Análise Fatorial Exploratória da Escala de Mitos e Crenças sobre o Suicídio (EMCS) ..................................................................... 40

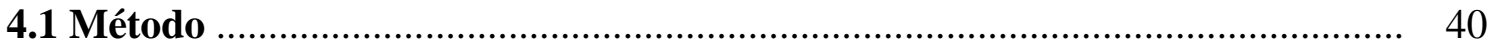

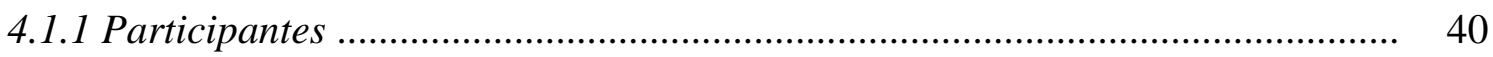

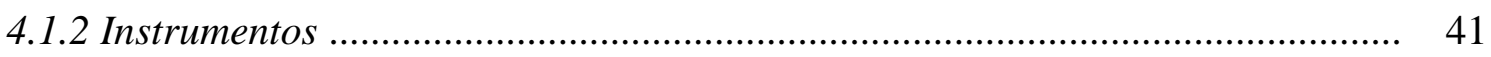

4.1.3 Procedimentos ................................................................................... 41

4.1.3.1 Coleta de dados ..................................................................................... 41

4.1.3.2 Análise de dados .................................................................................. 42

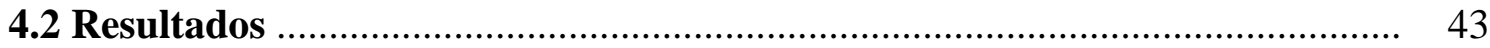

4.2.1 Caracterização da amostra ......................................................................... 43

4.2.2 Análise da estrutura fatorial .................................................................... 44

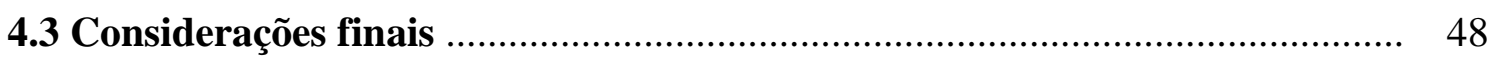


Capítulo 5 - Estudo 2 - Valores Pessoais e Organizacionais Relacionados a Mitos e Crenças sobre o Suicídio: Visão de Profissionais de Segurança ............. 49

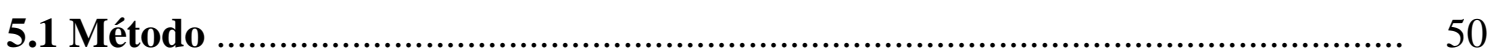

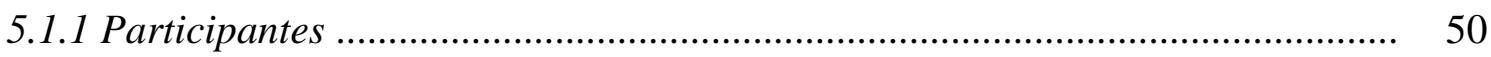

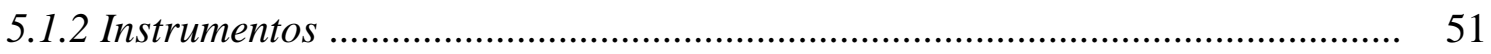

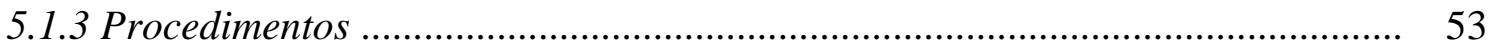

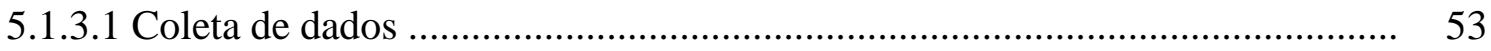

5.1.3.2 Análise dos dados ..................................................................................... 54

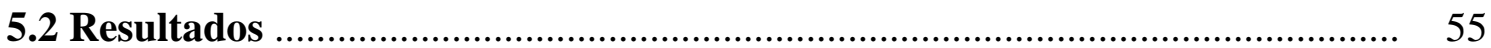

5.2.1 Caracterização dos participantes ............................................................. 55

5.2.2 Características psicométricas das escalas utilizadas para este estudo ............. 57

5.2.3 Relação entre as variáveis pessoais e mitos e crenças sobre o suicídio ............ 63

5.2.4 Mitos e crenças de profissionais militares (PM e CBM) sobre o suicídio ......... 65

5.2.4.1 Valores pessoais como preditores de mitos e crenças sobre o suicídio ........... 68

5.2.4.2 Valores organizacionais como preditores de mitos e crenças sobre o suicídio 70

5.3 Facilitadores e dificultadores do atendimento em tentativas de autoextermínio (TAE) e suicídio ..................................................................... 72

5.4 Considerações finais ........................................................................... 78

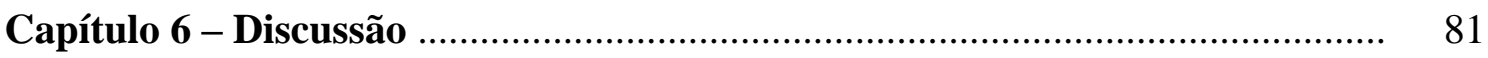

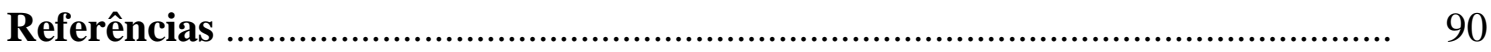

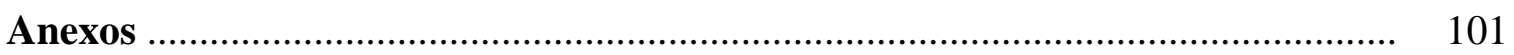

Anexo A - Estudo 1 - Termo de Consentimento para Participação em

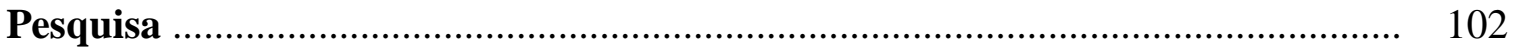

Anexo B - EMCS original - Estudo 1 .................................................... 104

Anexo C - Dados sociodemográficos - Estudo 1 .............................................. 107

Anexo D - Gabarito da EMCS, após análise fatorial, com 32 itens ................... 108

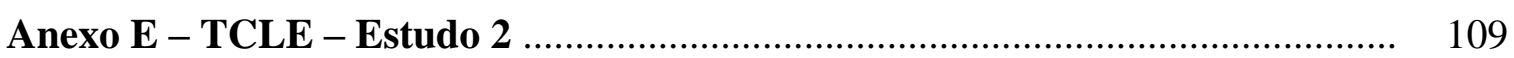

Anexo F - Questionário de Pesquisa - Parte 1 - EMCS .................................. 111

Anexo G - Autorizações de Pesquisa ............................................................ 116 


\section{Introdução}

Pretendeu-se, nesta tese, pesquisar sobre os mitos e as crenças de profissionais da área de segurança sobre suicídio, uma vez que o atendimento a vítimas é mediado por esses mitos e crenças. Isso acarreta, muitas vezes, a falta de compreensão abrangente do fenômeno e da própria pessoa. De acordo com Montenegro (2012), o suicídio é um fenômeno que apresenta causas multifatoriais, como aspectos biológicos, psicológicos e ambientais, além do contexto social-histórico-situacional e cultural.

Dados de 2000 estimam que a cada 40 segundos uma pessoa comete suicídio no mundo e que a cada três segundos uma pessoa atenta contra sua própria vida. Em 2004, essa foi a causa de 51,8\% das mortes intencionais, à frente dos homicídios $(36,9 \%)$ e dos conflitos bélicos (11,3\%). Em 2008, o coeficiente subiu para 16 casos por 100.000 habitantes, com projeção de 1,5 milhão de suicídios para o ano de 2020 (WHO, 2014). Esse fenômeno causa impacto psicológico, social e financeiro em, pelo menos, outras seis pessoas próximas. O suicídio está entre as 10 principais causas de morte no mundo e, nos últimos 45 anos, tornou-se a sexta causa de mortalidade global entre pessoas de 15 a 45 anos.

A classificação proposta pelo relatório de Prevenção ao Suicídio (WHO, 2014) considera que as taxas de suicídio são baixas (menos de 5 casos por 100.000 habitantes), médias (de 5 a 15 casos por 100.000 habitantes) e altas (de 15 a 30 casos por 100.000 habitantes). No Brasil, segundo dados do Datasus, em 2012, os suicídios responderam por 0,87\% da mortalidade geral, estatística que coloca o País na taxa média de suicídio: 5,32 casos por 100.000 habitantes naquele ano. Outros dados do Datasus também mostram que a região Centro-Oeste possuía, em 2012, a segunda maior taxa de suicídios do país $(6,46$ casos por 100.000 habitantes), perdendo apenas para a região Sul (8,5 casos por 100.000 
habitantes). Há também grandes diferenças quando se analisam as taxas de suicídio de diferentes estados. Pode-se exemplificar que o estado do Rio Grande do Sul apresentou, em 2012, a taxa de 10,95 casos por 100.000 habitantes, enquanto em Goiás a taxa foi de 6,53 casos por 100.000 habitantes, no mesmo ano.

Apesar de o Brasil encontrar-se no grupo de nações com taxas proporcionais reduzidas de suicídio, por ser um País populoso está em oitavo lugar na esfera mundial quanto aos números absolutos: em 2012, foram quase 12 mil casos (WHO, 2014). A proporção entre taxa de suicídio e gênero indica fortemente mais mortalidade entre os homens. Entretanto, embora a mortalidade masculina seja mais elevada, entre os anos de 1994 e 2004, houve um aumento proporcional de 16,4\% para os homens e de $24,7 \%$ para as mulheres. Embora elas sejam propensas a tentar o suicídio mais vezes, os homens tendem a obter maior número de resultados fatais devido aos métodos utilizados (Bando, 2012; Bando \& Lester, 2014; Bernardes, Turini, \& Matsuo, 2010). A taxa de suicídio entre os mais velhos ainda é considerada a mais alta. De um lado, um aumento crescente das taxas no grupo com idade de 20 a 59 anos tem sido observado em ambos os gêneros (Ferreira \& Trichês, 2014; Leite et al., 2011).

Não obstante os transtornos mentais estarem relacionados a mais de $90 \%$ dos casos de suicídio, esse evento também está associado a fatores culturais, sociais, ambientais e biológicos. Saxby Pridmore (2011) identificou que, no Ocidente, as autópsias psicológicas levaram à conclusão de que todos ou quase todos os suicídios são resultados de desordem mental. No entanto, o autor enfatiza que há reservas sobre o status científico de tais estudos.

Segundo Kock (2010), investigar a compreensão dos profissionais sobre o suicídio, baseando-se em suas crenças e mitos sobre esse ato, vai ao encontro de uma política que permite fornecer subsídios para treinamentos técnicos e suporte psicológico, visando 
melhorar a qualidade dos serviços oferecidos. Assim, conhecer as concepções dos profissionais de diferentes serviços permite aos setores de atenção à saúde e às políticas públicas associadas articularem discussões e proposições em relação à melhoria da atenção em saúde mental.

O trabalho dos profissionais de segurança que atendem ocorrências de suicídio é rodeado por sentimentos e emoções às vezes difíceis de classificar e identificar, que têm origens tanto no paciente como em si próprio. Os aspectos emocionais e a diversidade de estressores presentes no dia a dia afetam o trabalho e a qualidade de vida desses profissionais. Identificar essas emoções e aprender a gerenciá-las supõe a aquisição de novas ferramentas para realizar o trabalho com sucesso, preservando a saúde mental de profissionais da área de segurança (Kock, 2010).

Partindo dos dados epidemiológicos, verifica-se a importância da investigação do tema. Considera-se, ainda, essencial sua maior compreensão a partir da perspectiva dos profissionais de segurança, porque são eles os primeiros a entrar em contato com os pacientes. Nessa perspectiva, o objetivo desta tese é identificar os mitos e as crenças sobre suicídio em profissionais que atendem chamados de socorro a suicidas, bem como identificar associações entre mitos e crenças com valores pessoais e organizacionais. Partese do pressuposto, que os valores pessoais e organizacionais tem associação com a formação dos mitos e crenças, por esse motivo justifica-se entender essa relação.

O capítulo um apresenta o eixo teórico sobre suicídio, dados epidemiológicos e fatores de risco e proteção. Abrange a definição de mitos e crenças, e, posteriormente, descreve os profissionais que atendem a emergência em instituições militares, como a Polícia Militar e o Corpo de Bombeiros. 
O capítulo dois enfoca os temas sobre a cultura militar da Polícia Militar e do Corpo de Bombeiros Militar. Apresenta os eixos teóricos acerca de cultura e valores, tanto pessoais quanto organizacionais.

O capítulo três é composto pelos objetivos principais da Tese e também por três hipóteses decorrentes desses objetivos.

O primeiro estudo é apresentado no capítulo quatro e teve como objetivo proceder à análise fatorial exploratória da Escala de Mitos e Crenças sobre o Suicídio (EMCS). A escala foi validada em uma amostra de estudantes universitários de uma universidade privada de Goiânia, no estado de Goiás, que estavam matriculados nos cursos de Enfermagem, Medicina e Psicologia. Esse instrumento foi utilizado no segundo estudo, o principal da presente tese.

O estudo dois, apresentado no capítulo cinco, visa identificar mitos e crenças de profissionais militares (Polícia Militar - PM e Corpo de Bombeiros Militar - CBM) que atendem a chamados de socorro em casos de suicídio, bem como descrever associações entre mitos e crenças com valores pessoais e organizacionais. Ademais, o capítulo abrange a investigação dos objetivos específicos, a relação de variáveis pessoais, como religião, nível hierárquico e situação conjugal dos profissionais, além de crenças e mitos sobre o suicídio nas duas corporações militares de Goiás.

Por fim, o capítulo seis apresenta a discussão acerca dos resultados dos estudos, analisando-os a partir das teorias apresentadas nos dois primeiros capítulos. 


\section{Capítulo 1}

\section{Suicídio e Profissionais de Intervenção em Crise}

\subsection{Contextualizando o suicídio}

Freitas e Borges (2014, p. 40) definem suicídio como "o ato humano de causar a cessação da própria vida" e a tentativa de suicídio como o "ato de tentar cessar sua própria vida, porém sem consumação". Dentre os vários entendimentos sobre esse tema, seus significados e definições, há uma ideia central associada ao ato de "morte de si mesmo" (Cassorla, 2004). D’Assumpção, D’Assumpção e Bessa (1984) ressaltam a importância de não reduzir o suicídio a uma única causa ou razão, sendo importante percebê-lo em sua totalidade. O suicida tem vivências simultâneas que refletem o desejo de viver e morrer, como resultado de uma complexa rede conflituosa de fatores em interação (Cassorla, 2004).

Conte (2012) afirma que o suicídio é um fenômeno social que se caracteriza como importante problema de saúde pública. Dados da Organização Mundial da Saúde (OMS) mostram que houve um aumento de $60 \%$ nas taxas mundiais de suicídio nos últimos 45 anos, principalmente entre jovens do sexo masculino e em idade economicamente ativa (Minayo, 2012; WHO, 2013). Considerando as taxas de suicídio nas últimas décadas - e por ser um problema de saúde pública - foi elaborado um manual de prevenção do suicídio pelos profissionais do Ministério da Saúde, voltado, em especial, para o suporte de equipes de saúde mental (Ministério da Saúde, 2006).

Estudos variados têm sido realizados com a finalidade de conhecer esse fenômeno em sua amplitude, buscando, assim, identificar fatores de risco que vão além dos transtornos mentais, como sexo, profissão, estado civil e idade (Ramos \& Falcão, 2011), 
que podem auxiliar os profissionais na identificação de um potencial suicida, permitindo o início de uma abordagem preventiva.

Entende-se que os fatores que podem desencadear o ato suicida são diversificados: problemas financeiros; rupturas de relacionamento; desentendimento com ou perda de pessoas queridas, familiares ou amigos; problemas legais ou de saúde; uso excessivo de álcool e outras drogas, transtornos psiquiátricos; doenças físicas dolorosas e/ou incapacitantes; abuso físico ou sexual na infância; caso anterior de tentativa ou história de suicídio na família, bem como acesso fácil a instrumentos para se matar (Minayo \& Cavalcante, 2015; Werlang \& Botega, 2004). Minayo e Cavalcante (2015) levantam, em sua pesquisa, que alguns autores defendem que a depressão constitui o mais relevante fator de risco para tentativas de "dar cabo à vida", partindo do pressuposto de que essa é a chave para a compreensão do problema. Além dos fatores desencadeantes do suicídio, existem aqueles que protegem o indivíduo desse ato: bons vínculos afetivos, sensação de estar integrado a um grupo ou comunidade religiosa, estar casado (a) ou com companheiro (a) fixo e ter filhos pequenos (Botega, Werlang, Cais, \& Macedo, 2006).

No plano individual, a morte de si mesmo pode ser caracterizada por uma ação consciente, ou seja, deliberada e intencional, como também pode provir de impulsos de autodestruição, onde o indivíduo procura a morte por meio de atos e comportamentos inconscientes, provocando mortes "naturais", ou seja, o indivíduo alimenta, facilita, aumenta ou apressa o processo de sua morte (Cassorla, 2005).

Com base nos autores anteriormente citadose no conceito de novas formas de produção de subjetividade, de sofrimento psíquico e de psicopatologias, considera-se que o suicídio é vivenciado como a melhor solução para escapar de uma dor psicológica insuportável (Lazzarini \& Viana, 2006). Essa dor inicia-se por meio de sentimentos negativos (culpa, vergonha, angústia, pânico, solidão, desesperança), que se tornam 
pensamentos recorrentes de procura da própria morte (ideação suicida), como o estímulo para colocar um fim em emoções intoleráveis, que podem se fortificar ao longo do tempo, abrindo espaço para o plano suicida, transformando ideia em ato (Werlang, Macedo, \& Krüger, 2004).

Devido à atitude interna ambivalente (viver ou morrer), o indivíduo, ao mesmo tempo em que quer alcançar a morte, emite sinais verbais e/ou comportamentais sobre essa intenção às suas relações interpessoais, expressando que algo precisa ser mudado (Werlang et al., 2004). Faberow, Simon e Rudestam, citados por Holmes (2004), organizaram entrevistas com amigos e parentes de suicidas e verificaram que 60 a $70 \%$ das vítimas verbalizaram o desejo de suicidar, mediante ameaças diretas, e que 20 a $25 \%$ se referiram, em algum momento, ao assunto, com indicação indireta de intenções.

Para Durkheim (1982), o ato de suicidar-se está ligado às características individuais dos suicidas, entretanto, origina-se no meio que o rodeia, no âmbito da sociedade. Assim, o suicídio é a trágica denúncia individual de uma crise coletiva - um fato social - e pode ser estimulado ou detido pelo ambiente. $\mathrm{O}$ fato social tem como característica ser externo, não inerente e exercer uma coerção social sobre os indivíduos, fazendo com que se conformem com certas práticas. Os indivíduos buscam suas respostas de vivência de valores a partir dos meios sociais, sendo eles a base para as relações sociais. Dessa forma, é importante considerar os aspectos sociais que cercam o ato suicida, pois é um evento que ocorre e está intimamente ligado a um contexto social de várias maneiras, desde a sua origem até a sua significação (D’Assumpção et al., 1984).

De acordo com Rezende (1986), citado em Cassorla (2005), a dinâmica de um grupo é resultante do conjunto das interações no interior de um espaço psicossocial. Essas interações poderão ser tensões, conflitos, repulsas, atrações, trocas, comunicações ou, ainda, pressões e coerções. A interação entre fatores internos (individuais) e externos 
(sociais) sempre existe, porém, o indivíduo com ideação suicida não possui forças para enfrentar uma pressão externa, por sua intensidade, pelo prejuízo de forças internas ou pela soma de ambos os fatores (Cassorla, 2005).

Para Bertolote e Fleischmann, citados por Meleiro, Fensterseifer e Werlang (2004), o suicídio permanece como um grave problema de saúde pública, apesar das possibilidades de prevenção em inúmeros casos por meio de diversas estratégias. Todavia, uma ação preventiva eficiente depende de integração e coordenação multissetorial. O Brasil é o primeiro país da América Latina a elaborar e apresentar Diretrizes Nacionais de Prevenção do Suicídio, que assinalam a necessidade de: desenvolver estratégias de promoção de qualidade de vida e de prevenção de danos; organizar a rede de atenção e intervenções nos casos de tentativas de suicídio; promover a educação permanente dos profissionais de saúde da atenção básica, inclusive da Estratégia Saúde da Família, dos serviços de saúde mental, das unidades de urgência e emergência, de acordo com os princípios da integralidade e da humanização (Botega, 2004).

A prevenção do suicídio deve ser feita mediante reforços dos fatores protetores e do levantamento e da diminuição dos fatores de risco, tanto em âmbito individual como coletivo (Botega et al., 2006). Entre os fatores de proteção, merecem destaque: a existência de uma rede social de apoio, a flexibilidade para enfrentar adversidades da vida e a viabilização de políticas que facilitem a procura de auxílio profissional, quando isso for necessário.

Embora não seja possível prever o suicídio, é importante que os profissionais que atuam no socorro a esses casos tenham parâmetros para identificar seus indícios, avaliar os níveis de risco e intervir nas situações. O profissional pode ser um facilitador que ajudará o indivíduo a desvelar seus interesses pela vida, dando-lhe consciência das suas necessidades e responsabilidades de estar vivo (Fukumitsu, 2005). 
Para tanto, é imprescindível entender como os profissionais se posicionam em seu cotidiano frente ao fenômeno do suicídio, para que a atuação seja baseada em treinamento adequado e menos pautada nos mitos e nas crenças sociais. Sabe-se ainda que esse posicionamento diante de qualquer fenômeno social é pautado nos valores pessoais e, consequentemente, partilhado na organização.

\subsection{Mitos e crenças}

Segundo a OMS (2000), existem mitos acerca dos comportamentos suicidas e eles necessitam ser elucidados para que a população identifique padrões comportamentais que possam levar a um ato suicida. Sabe-se que o tema morte é um tabu na sociedade e, muito mais ainda, quando se trata de morte voluntária ou suicídio. De qualquer modo, é imprescindível identificar esses comportamentos no intuito de realizar uma abordagem preventiva e eficaz a favor da vida.

Mitos são entendidos como um segredo, uma crença inconsciente ou uma atitude que - devido a uma ampla aceitação pelas gerações sucessivas de uma família ou grupo social - perpetuam-se na determinação de suas condutas (Pincus \& Dare, 1981). Os mitos tendem a frutificar e se desenvolver especificamente sobre a falta ou escassez de dados e/ou de explicações plausíveis (Andolfi \& Angelo, 1989). Esses vazios informacionais são preenchidos pela formação de estereótipos que induzem as pessoas a determinados comportamentos.

Rudd et al. (2006) afirmam que, na ausência de premissas que expliquem determinado fenômeno, atribuindo a ele um conjunto de funções, nascem os mitos e estes fazem parte de práticas sociais: são importantes na composição do arcabouço cultural de uma sociedade. Não se configuram como problema em si mesmo, antes, o problema potencial pode decorrer do uso que se faz do mito, de sua função. Quando ele é tido como 
verdade única e utilizado para balizar decisões éticas, tem-se então um problema. Em relação ao suicídio, irrigado pelo mistério que é característica do tabu, o mito encontra, então, fertilidade.

Já o termo crença, baseando em Löwy (1985), é utilizado de diversas formas e enfoques. Assim, do ponto de vista psicológico, pode aparecer sob as palavras pensamento, representação, orientações cognitivas, saberes, além de valores, expectativas, perspectivas e atitudes. São todas categorias vistas como parte da cultura do indivíduo e pano de fundo do contexto em que ele toma decisões diante de situações específicas, definindo tanto o seu pensamento quanto a sua ação. Do ponto de vista filosófico ou sociológico, esse vocábulo se torna ainda mais circular, pois são várias as correntes e cada uma tem a sua própria linguagem para se referir a ele. Podem-se analisar as crenças e encontrá-las situadas no interior de outros temas, ou seja, subjacentes a algumas categorias mais abrangentes, tais como ideologias, senso comum, visão social de mundo, conjuntos estruturadores de valores, representações, ideias, teorias que se orientam para a sua estabilização ou legitimação, ou reprodução da ordem estabelecida ou que aspiram a outra realidade ainda não existente (Löwy, 1985). Dessa forma, entende-se que crença é uma concepção de um fato, mais forte, firme e constante do que seria possível se obter apenas pelo processo de imaginação.

Krech, Crutchfield e Ballachey (1975) afirmam que a crença possui uma forma de organização com propriedades estruturais, com consequências comportamentais capazes de serem observadas e analisadas, visto que são inferências. Os tipos de crença podem ser vistos como relativamente superiores em organização lógico-funcional ou em comunicação funcional, por exemplo: existenciais versus não existenciais; compartilhadas versus não compartilhadas sobre a existência e a autoidentidade; derivadas versus não derivadas e relativas e não relativas a questões de preferência. 
Ainda de acordo com os autores, estruturada essa condição da crença, ela pode ser qualquer uma das propostas capazes de serem precedidas pela frase "eu creio que...", na qual o conteúdo pode descrever o seu objeto como verdadeiro oposto, do tipo correto ou incorreto, devendo-se aliar à natureza da atitude, onde Allport reconhece três pontos de origem do conceito moderno de atitude: na Psicologia Experimental; na Psicanálise; e na Sociologia.

Rokeach (1981) explica que a maioria dos teóricos concorda que a atitude não é um elemento básico irredutível da personalidade, mas a representação do agrupamento de dois ou mais elementos inter-relacionados. A concepção da atitude como uma organização de crenças é coerente com a opinião de Krech et al. (1975) de que todas as atitudes incorporam crenças, mas que nem todas as crenças fazem parte, necessariamente, das atitudes, sendo que elas têm apenas um comportamento cognitivo, enquanto as atitudes são ainda cognitivas e afetivas.

Ainda segundo Krech et al. (1975), a função da crença é estabelecer a conexão com os valores, que têm a ver com os modos de conduta. Uma vez que um valor é internalizado, ele é tido como um padrão ou critério para guiar a ação e, assim, desenvolver e manter as atitudes em relação a objetos e situações relevantes, para julgar e comparar, moralmente, a si e aos outros. Os valores diferem das atitudes em vários aspectos importantes: enquanto uma atitude representa diversas crenças focadas num objeto ou situação específica, um valor é uma única crença, que guia transcendentalmente as ações e os julgamentos por meio de objetos e situações específicas. Ou seja, segundo os autores, um valor é um imperativo para a ação, e não somente uma crença sobre o preferível.

Por meio deste estudo, pretende-se compreender mitos e crenças acerca do suicídio e do comportamento suicida. Ademais, a investigação dos valores pessoais e 
organizacionais pode esclarecer e/ou identificar (in) verdades que têm contribuído para a manutenção do estigma, da desesperança, bem como da restrição do acesso à ajuda para muitos que sofrem com ideações ou histórico de tentativas de suicídio. Dessa forma, esta pesquisa parte da premissa de que os valores humanos são baseados em mitos, crenças e atitudes, hipotetizando-se que os valores preservam a essência das pessoas em sua atividade profissional, possibilitando vivências plenas, positivas ou negativas.

\subsection{Profissionais de segurança no atendimento a tentativas de autoextermínio}

Sabe-se que, no Brasil, os pedidos de socorro decorrentes do comportamento suicida acionam os serviços de emergência como bombeiros, polícia, profissionais da emergência médica (Serviço de Atendimento Móvel de Urgência - SAMU) e de saúde mental, entre outros. Trata-se de várias possibilidades de atuação e de mobilização de equipes, visto que podem se constituir de tentativas de suicídio, ameaças com ou sem planejamento, ou mesmo o suicídio já consumado (O’Carroll, Berman, Maris, Moscicki, Tanney, \& Silverman, 1996; Portela, 2012; Rodgers, Sudak, Silverman, \& Litts, 2007; Werlang \& Botega, 2004).

Com base no trabalho de Portela (2012), o termo emergência se refere a uma situação de grande risco e de agravo à saúde, que surge bruscamente e demanda uma intervenção imediata para evitar danos ou mesmo a morte de um indivíduo. Já o termo urgência se refere à "qualidade de uma situação, que indica a demanda de uma ação premente, que não necessariamente surge subitamente, mas que detém prioridade sobre as várias outras" (Portela, 2012, p. 24).

No Brasil, a busca pelo socorro varia de estado para estado da federação, sendo o mais comum a atuação da Polícia Militar em casos de suicídios consumados e o acionamento do corpo de bombeiros e/ou Serviço de Atendimento Médico de Urgência 
(SAMU) em ocorrências de tentativas de suicídio. No entanto, dependendo da modalidade de Tentativa de Autoextermínio (TAE), a atuação de cada instituição pode ser mais ou menos eficaz. Por exemplo, se há presença de armas de fogo e de artefatos explosivos em uma situação de TAE, a polícia é a instância mais indicada a ser acionada. Se há um estado de intoxicação medicamentosa, deve-se acionar o SAMU. Os bombeiros têm atuação mais efetiva - devido ao seu treino em habilidades táticas de resgate e salvamento - e apropriadas para TAEs com salto de lugares altos e afogamento, por exemplo, e com a presença de estados de agitação e agressividade (Portela, 2012, p. 35). Ademais, sabe-se das diferenças culturais e organizacionais de cada instituição, levando a treinamentos operacionais e atuações práticas distintas. Por outro lado, é evidente a falta de suporte psicológico a equipes que atuam em urgências e emergências (OMS, 2009).

A Polícia Militar (PM) é uma instituição permanente, organizada com base na disciplina e na hierarquia, que tem como principais atividades o policiamento ostensivo e a preservação da ordem pública. O Corpo de Bombeiros Militar (CBM), em contrapartida, é estruturado como uma corporação independente e autônoma, com as seguintes missões: execução de atividades de defesa civil; prevenção e combate a incêndios e a situações de pânico, assim como ações de busca e salvamento de pessoas e bens; desenvolvimento de atividades educativas relacionadas à defesa civil e à prevenção de incêndio e pânico, bem como análise de projetos e inspeção de instalações preventivas de proteção contra incêndio e pânico nas edificações (Goiás, 1989). Essas atividades das corporações apontam para a grande importância do socorro a vítimas de acidentes e casos semelhantes.

Os profissionais da polícia estão entre os primeiros a atender a ocorrências de suicídios consumados e, portanto, tendem, muitas vezes, a absorver os efeitos psicológicos dessas experiências. Em geral, após o atendimento de um caso de suicídio, os policiais são esperados para atuar em atividades distintas, como proteger o meio ambiente e investigar 
outros episódios. Muito pouco suporte psicológico tem sido disponibilizado àqueles militares que vivenciam essa situação específica (Kock, 2010; Portela, 2012). Sabe-se que as corporações militares têm se dedicado ao treinamento técnico, mas o pós-evento precisa ser melhordimensionado e valorizado nos procedimentos das instituições.

Segundo Bastos e Gondim (2010a, 2010b), torna-se muito difícil pensar em apenas uma variável explicativa acerca do contexto do trabalho das corporações policiais. Deve-se pensar nas interações de fatores individuais e sociais. Esses autores fizeram um diagnóstico do trabalho de policiais apoiados em seus relatos verbais e sintetizaram: tratase de trabalho fragmentado, com pouca significação, aliado a fracas relações sociais, chefias autoritárias e pouco propensas ao diálogo, excesso de trabalho - ou o oposto, falta de trabalho por questões relacionadas com o poder ou medidas punitivas, que pode se constituir em assédio moral - e pouco auxílio do setor de recursos humanos para superar as dificuldades. Esses foram fatores relacionados com a deterioração psíquica dos entrevistados. A conclusão dos autores foi reveladora, pois os participantes relataram que os problemas vivenciados pelo indivíduo são entendidos como fazendo parte das situações do trabalho e "enquadrados" como decorrência da profissão. É previsível, portanto, que as condições externas sejam supervalorizadas em detrimento de fatores internos do profissional.

Com o propósito de identificar a literatura sobre o tema, foi realizada pesquisa em base de dados com a palavra suicídio (suicide) e tentativas de suicídio (attempts suicide), obtendo-se 9.560 artigos, 2.366 revisados pelos pares e 768 específicos com a palavra "suicídio". Após a adição dos filtros humans, adults e prevention, bem como dos termos equivalentes em português, foram encontrados 368 trabalhos. Posteriormente, excluíram-se as resenhas, atas de congressos e recursos textuais, obtendo-se 344 artigos. Filtrando ainda mais, analisando o período entre 2010 e 2015, sobraram 98 artigos e, em língua inglesa, 
96. Excluindo os artigos específicos de suicídio de gênero, terrorismo e em população carcerária, o número caiu para 50 e, destes, restaram 16, que englobavam pesquisas com profissionais de emergências. Todavia, específicos sobre atendimento, não tratando de suicídio de profissionais, o resultado final foi de apenas quatro artigos (Deuter et al., 2013; Freitas \& Borges, 2014; Kock, 2010; Osafo, Hjelmeland, Akotia, \& Knizek, 2011).

Kock (2010), em seu estudo com policiais, afirmou que a cultura organizacional define a instituição e, em consequência, o contexto no qual ocorrem as experiências traumáticas e a superação destas. Em muitos casos, a instituição policial não propicia os subsídios e o suporte que seus profissionais precisam para se recuperar de exposições traumáticas. Uma vez que as prescrições dos procedimentos-padrão só descrevem as circunstâncias do papel profissional, a maioria é deixada sem estratégias para lidar com a sua vida emocional após a conclusão do trabalho. O fato de que policiais podem ter mobilizações psicológicas nas vivências de suicídios consumados - e que podem precisar de assistência para a compreensão desses sentimentos - não foi abordado no treinamento da polícia de qualquer um dos participantes do estudo de Kock (2010). Assim, os planos de treinamento da instituição tinham foco exclusivo em procedimentos de investigação em casos de atendimento a suicídios.

Kock (2010) analisou os relatos de policiais e eles afirmaram que o papel profissional não os protege contra ocorrências de suicídios; em vez disso, eles são treinados para percebê-las como algo não traumático, mas sim "parte do trabalho". De forma contrária, a maioria dos participantes considerou a experiência de encontrar um suicídio consumado como traumática e alguns oficiais relataram um alto índice de conscientização de sua própria possibilidade de morte, enquanto outros policiais referiram pensamentos suicidas próprios. 
Alguns pesquisadores argumentaram que a formação recebida tem sido insuficiente na preparação de um policial para lidar com respostas pessoais a suicídios consumados (Danto, citado por Kock, 2010; Heinsen, Kinzel, \& Ramsey, 1999; Nicoletti \& SpencerThomas, 1999). Sabe-se que apenas recentemente a polícia reconheceu os efeitos da emoção sobre a atuação profissional e o quão profundamente a competência quanto à inteligência emocional afeta o desempenho operacional do policial. Os pesquisadores sugerem que o treinamento aborde que se deparar com suicídios consumados é provável, o que gera reações emocionais, tanto na cena do ato suicida quanto em momentos posteriores à experiência, durante os períodos de folga.

Já no caso do Corpo de Bombeiros Militar, há um treinamento técnico baseado em procedimento operacional padrão (POP). Geralmente, a sequência de atuação no primeiro socorro em tentativas de suicídio é deslocamento, aproximação, avaliação, negociação, contenção física e encaminhamento. Entretanto, a contenção e a negociação dependerão das condições da tentativa do ato suicida (Portela, 2012). Esse autor estudou 15 bombeiros no Distrito Federal, com o objetivo de investigar como as crenças dos militares em relação ao suicídio influenciavam na ação do profissional. Nessa pesquisa, foram identificados mais relatos sobre habilidades corporais e praticamente nenhum treinamento em habilidades para negociação, segundo os participantes. As análises das falas dos bombeiros revelaram, ainda, que eles percebiam as vítimas de tentativas de suicídio como pessoas desesperançosas, com baixa capacidade de resolução de problemas, frágeis e descontrolados emocionalmente. Ademais, os relatos mais frequentes foram os de que as pessoas que tentam suicídio o fazem para chamar a atenção ou aparecer, além de se tratar de um ato covarde. Portanto, no estudo pode-se verificar a presença de mitos e crenças sobre pessoas que empreendem um ato suicida. 
Essas concepções podem incidir nos primeiros socorros com o poder de influenciar a tomada de decisão e, consequentemente, a escolha das estratégias do profissional. Por exemplo, se o bombeiro acredita que a contenção física é a prioridade, pouca probabilidade haverá para a negociação, por exemplo. A interpretação que o bombeiro faz da situação do indivíduo pode afetar sua atitude e capacidade de empatia, prejudicando o salvamento e o resgate. Entender a TAE como fingimento ou manipulação pode eliciar até mesmo sentimentos de raiva no socorrista e, em consequência, a retaliação na via contratransferencial, conforme proposto por Ouzouni e Nakakis (2009), Maltsberger (1996) e Freemouw, Perczel e Ellis (1990), o que pode redundar em desfechos drásticos.

Em relação às emoções relatadas pelos bombeiros, verificou-se que a maioria citou a satisfação nos casos de sucesso da operação e a sensação de impotência quando não conseguiam efetuar o socorro. $\mathrm{O}$ autor concluiu que o profissional socorrista precisa de informações e treinamentos para práticas preventivas e atuação diante de TAEs, pois suas crenças e mitos podem influenciar negativamente a sua atuação (Portela, 2012). Portela (2012) considera, ainda, que os altos índices de TAE se caracterizam como uma das grandes emergências psicológicas e psiquiátricas, por iniciar um processo que pode causar danos graves à saúde, ou mesmo a morte. Dessa forma, tanto profissionais de saúde mental como de segurança pública, apesar de possuírem treinamentos em emergências, "ao presenciar o momento de ocorrência de uma TAE, podem questionar a sua própria capacidade de operar a fim de favorecer a resolução efetiva dessa crise" (Portela, 2012, p. 22).

Lidar com indivíduos em risco de suicídio não é tarefa fácil. A literatura aponta que é comum o uso de crenças pessoais, por parte de profissionais que atuam em emergências, na tentativa de ajudar essas pessoas. Tem-se, então, uma série de possibilidades para compreender os significados atribuídos às tentativas de suicídio e ao impacto destas sobre 
a prática de profissionais que atendem emergências (Freitas \& Borges, 2014). Com base nesses estudos, considera-se que a formação profissional continuada é de extrema importância para diminuir julgamentos e regras morais, de modo que se elaborem e fortaleçam estratégias de prevenção ao suicídio.

Osafo et al. (2011) consideram que a melhor forma de promover a compreensão do comportamento suicida é examinar as atitudes das pessoas em relação ao ato e como o concebem. Ele realizou uma pesquisa, por meio de análise fenomenológica, na qual interpretava as atitudes em relação ao suicídio de pessoas em geral (leigos) em Gana. Foi investigado como o suicídio teve efeitos e influenciou a vida de terceiros, com o objetivo de discutir as implicações para a prevenção do suicídio nesse local. Os resultados mostraram que a representação do suicídio é a de que esse ato é uma lesão social, visão que acaba influenciando atitudes negativas dos participantes em relação aos suicidas, expressas em termos indiretos. Assim, o suicídio é visto como um ato imoral, porque afeta negativamente pessoas da comunidade.

Estudos apontam a necessidade de que profissionais de segurança reflitam e aprendam em relação às complexidades da prática de atendimento de emergências e urgências, bem como desenvolvam uma abordagem sistemática para a gestão de suicídio (Deuter et al., 2013). Ademais, pesquisas e experiências profissionais como a de Freitas e Borges (2014), Portela (2012), Kock (2010) e Deuter et al. (2013) indicam a necessidade de capacitação acerca dessa temática, por meio de atividades de atualização e apoio permanente. Faz-se necessário pensar em estratégias que consigam prevenir o suicídio e, ao mesmo tempo, oferecer conhecimentos que levem a um olhar menos pautado em julgamentos e regras morais. Esse novo olhar sobre o suicídio possibilitaria que a pessoa em sofrimento psíquico fosse acolhida em qualquer contexto e, consequentemente, tivesse melhores chances de recuperação e de reabilitação social. 


\section{Capítulo 2}

\section{Valores Pessoais e Organizacionais em Instituições Militares Brasileiras}

No Brasil, o sistema rígido das corporações militares deve ser entendido historicamente, a partir do seu surgimento. Fernandes (1973) afirmou que o militarismo ou as forças repressivas, como eram denominadas - típico do período colonial deve ser compreendido no quadro do processo de colonização, no qual desempenhou papel primordial no processo de preservação dessa formação social colonial. Ele estava relacionado à irreversibilidade e à crescente complicação dos conflitos coloniais. O militarismo veio para suprir a necessidade de preservar o status quo do Brasil colônia, garantindo, assim, o equilíbrio das relações sociais, de acordo com a própria intensidade da luta de classes.

Para compreender os valores organizacionais, primeiramente serão apresentadas as origens do militarismo brasileiro, enfocando, sobretudo, os fatores históricos que influenciaram fortemente a formação de nossas corporações militares. Em seguida, essa discussão será articulada com a problemática do autoritarismo, enfatizando a distinção entre esse conceito e o conceito de autoridade. O terceiro tópico abordado referir-se-á à questão das relações existentes nesse ambiente profissional, entendido como componentes dos valores pessoais e organizacionais.

\subsection{Raízes do militarismo brasileiro}

Do período colonial até meados do século XX, no âmbito federal, as Forças Armadas serviam aos interesses dos grupos oligárquicos hegemônicos. No plano estadual, as forças policiais correspondiam aos partidos políticos regionais e sua missão era, a 
princípio, defender o governo local contra os excessos da União e as classes dominantes contra manifestações de protesto de classes populares (Bicudo, 2000).

Para cumprir esses objetivos, fazia-se necessária uma organização funcional dessas corporações, o que ocasionou a vinda do Exército francês para treinar os elementos das forças policiais com as mais modernas instruções da arte militar. O sistema policial foi organizado baseado na disciplina, a mesma que imperava no Exército. Inclusive, vigorava a pena de morte nessa corporação, só extinta em 1851.

Existem vários processos relacionados com o surgimento e o desenvolvimento da Polícia Militar no Brasil. Todavia, um dos mais importantes refere-se à doutrina e ao treinamento unilateralmente articulados. Tanto nos cursos destinados aos recrutas e aos cabos, como naqueles destinados a oficiais, visava-se - além do treinamento de agentes, em termos da execução ideal de suas funções repressivas -, uma doutrinação que se dava indissoluvelmente ligada ao próprio treinamento. Esse processo acarretava o surgimento de um ideal não só do bom soldado, como também do bom militar. Assim, naquele período, colocava-se como princípio integrativo do grupo e, portanto, da instituição, o uso da força e, sobretudo, da repressão.

$\mathrm{Na}$ época da ditadura militar, as Forças Armadas institucionalizaram um discurso de liderança, "articulado aos princípios da Doutrina de Segurança Nacional e Desenvolvimento e à concepção de que as corporações militares e os valores de disciplina e hierarquia constituíam um modelo superior para organizar a sociedade e integrar a nação" (Carvalho, 2005, p. 117). Nota-se que a estrutura interna disciplinar das instituições de segurança é antiga, presente em todos os momentos históricos, e coincide com o discurso disciplinar da nação. Verifica-se, então, uma norma institucional explícita de não questionamento, de seguimento das determinações do comando, no sentido de manter a ordem social (interna ou externa às corporações). Surgem, com isso, os abusos de 
autoridade, pois os militares seguem o lema da força necessária para garantir a ordem (Guimarães, Torres, \& Faria, 2005). Contudo, deve-se estabelecer a distinção entre autoritarismo e autoridade, presentes na cultura organizacional militar.

As práticas autoritárias podem ser analisadas no contexto dos estudos sobre o autoritarismo em geral. As crenças autoritárias destacam o princípio hierárquico e fundamentam-se na desigualdade natural ou social entre os homens. Stoppino (1993) defende que as teorias sobre autoritarismo podem ser organizadas em três perspectivas: a personalidade autoritária, o autoritarismo cognitivo e o autoritarismo da classe trabalhadora.

Adorno, Frenkel-Brunswik, Levinson e Sanford (1950) propuseram a análise da personalidade autoritária, sendo o principal pressuposto teórico desse trabalho a investigação de um conjunto de traços: submissão, agressividade, crença alucinada nas autoridades, obediência aos superiores, falta de consideração com os inferiores, rigidez e conformismo. Esses autores defendem que o desenvolvimento da personalidade em ambientes repressivos, rígidos e severos levaria o indivíduo, desde a infância, ao deslocamento dos impulsos agressivos contra os pais para outros alvos, preferencialmente membros de grupos minoritários, percebidos como inferiores.

A teoria da personalidade autoritária (Adorno et al., 1950) explica que as reações autoritárias são consequências do não desenvolvimento de estratégias para lidar com situações de crise, o que sobrecarrega o estado emocional e cognitivo do indivíduo, levando-o a agir de maneira hostil. Com relação a esse tipo de ação, Oesterreich (2005) afirma que existem duas situações em que os indivíduos com personalidade autoritária são agressivos: quando seus superiores mandam e quando seus superiores não podem ajudar, em situações de crise, porque também estão sendo atacados. 
Posteriormente, Altemeyer (1981, 1988, 1996) afastou o conceito de autoritarismo da visão psicanalítica de Adorno et al. (1950) e o aproximou da Teoria da Aprendizagem Social, de Albert Bandura (1973). De acordo com Smith e Winter (2002), Altemeyer defende que o autoritarismo desenvolve-se no processo de aprendizagem social por meio da observação, da modelagem e do reforçamento. Nesse caso, a adolescência foi apontada por ele como um dos períodos mais importantes no processo de desenvolvimento de crenças e atitudes sobre autoridade e convenções sociais.

Altemeyer conceituou o autoritarismo de acordo com três grandes construtos atitudinais: a agressão autoritária, a submissão autoritária e o conservadorismo (Altemeyer, 1981, 1988, 1996). Assim, a combinação dessas três atitudes definiria uma mais conservadora. Recentemente, Feldman (2003, p. 66) sugeriu que a teoria sobre o autoritarismo deveria abordar "o conflito entre a ordem social baseada na conformidade social e o desejo de maximizar a autonomia pessoal". Para ele, deve-se investigar a relação do autoritarismo com os valores sociais. Desse modo, no contexto das corporações militares, deve-se analisar a dinâmica de funcionamento de crenças e valores dos superiores hierárquicos com os subordinados, pois, na prática, o que se observa é um conflito entre autoritarismo e autoridade.

A autoridade não pode ser confundida com práticas autoritárias violentas. De acordo com Arendt (1972), a autoridade exclui coerção, mas não pode ser compatível com persuasão, uma vez que, de acordo com Paula e Silva (2001), essa última pressupõe uma relação de igualdade. A diferenciação de quem manda e de quem obedece, numa situação de autoridade, é a hierarquia. Segundo a concepção apresentada por Weber (1944) e Arendt (1972), para que haja autoridade é necessário um reconhecimento da sua legitimidade, tanto pela chefia quanto pelos subordinados. Portanto, a relação de hierarquia precisa ser considerada legítima para que se possa estabelecer a relação de autoridade. 
Esta, em uma organização burocrática, provém das regras estabelecidas e dos cargos hierarquicamente organizados. Esse é o caso das corporações militares.

Atualmente, vigora o artigo 124 da Constituição Estadual de Goiás, promulgado em 05 de outubro de 1989, que define as funções gerais competentes à área da Segurança Pública (Goiás, 1989). Nela, verifica-se que a Polícia Militar é caracterizada como uma instituição permanente, organizada com base na disciplina e na hierarquia, e que tem como principais atividades o policiamento ostensivo e a preservação da ordem pública.

O Corpo de Bombeiros, em contrapartida, é estruturado como uma corporação independente e autônoma, com as seguintes missões: execução de atividades de defesa civil; prevenção e combate a incêndios e a situações de pânico, assim como ações de busca e salvamento de pessoas e bens; desenvolvimento de atividades educativas relacionadas à defesa civil e à prevenção de incêndio e pânico; e análise de projetos e inspeção de instalações preventivas de proteção contra incêndio e pânico nas edificações (Goiás, 1989).

Tomadas em conjunto, essas atividades apontam para a grande importância das corporações militares para uma convivência em sociedade harmoniosa. Assim, o bem-estar desses profissionais configura-se como categoria fundamental de análise. Entretanto, fazse necessário complementar o estudo sobre autoritarismo e autoridade com a distinção entre construtos intimamente relacionados, haja vista que a ênfase na hierarquia pode funcionar como um facilitador para o surgimento de relações interpessoais caracterizadas por ações agressivas, violentas, retaliatórias e assediadoras (Guimarães, Torres, \& Mendonça, 2012).

Em situações extremas, nas quais o trabalhador sente-se acuado, podem acontecer casos de adoecimento psíquico, uso de álcool e outras drogas, levando a afastamentos do trabalho e, também, a situações de suicídio. De acordo com Dejours e Bègue (2010), todos esses tipos de adoecimento têm como fatores causadores os processos alienantes do 
ambiente de trabalho. O contexto da organização militar favorece o processo de individualização, que retira dos trabalhadores as estratégias coletivas defensivas que os protegem do sofrimento patogênico no trabalho.

\subsection{Cultura, valores pessoais e organizacionais}

Definir cultura não é nada fácil, visto a diversidade de conceitos existentes, que perpassam por teorias antropológicas, sociológicas e psicológicas (Paz \& Tamayo, 2004). Por exemplo: os advogados utilizam a palavra cultura para indicar alguém com diversidade de conhecimento (pessoa culta); já os antropólogos referem-se aos rituais e costumes adquiridos e desenvolvidos na história da sociedade; os psicólogos organizacionais usam esse termo quando se referem ao clima e às práticas organizacionais desenvolvidas para lidar com pessoas, com seus valores e credos organizacionais (Schein, 1986).

A dificuldade em conceituar cultura faz com que não exista uma unanimidade entre os estudiosos, o que implica a variabilidade conceitual devido à complexidade desse fenômeno e, consequentemente, os desafios para unir, em um único conceito, os numerosos componentes da cultura, assim como as interações entre eles. Nesse sentido, para este estudo, toma-se como enfoque a psicologia social organizacional e, portanto, entende-se como cultura a "programação coletiva da mente que diferencia os membros de um grupo humano de outros" (Hofstede, 1980, p. 21), composto pelos fatores valores, justiça, ritos, mitos e estilos de funcionamento organizacionais (Paz \& Tamayo, 2004). No entanto, foca-se nos valores organizacionais e nos mitos que podem ser formados por esses valores.

A cultura organizacional governa as relações existentes em uma organização. Esta, por sua vez, é conhecida por seu funcionamento, pela análise relacionada aos elementos 
discriminatórios, integradores e compartilhados pelos trabalhadores. Canova e Porto (2010) enfatizam que a cultura organizacional é constituída por um conjunto de valores organizacionais que norteiam e precedem os comportamentos das pessoas nas organizações. Desse modo, a cultura organizacional está implícita nos papéis, nas normas e nos valores organizacionais (Tamayo, 1996).

De acordo com Schein (1986), a cultura organizacional está pautada em um conjunto de pressupostos básicos, inventados e descobertos por um grupo, em resposta aos processos de aprendizagem que ocorrem, para lidar com problemas que requerem adaptação externa e integração interna. Por possibilitarem uma convivência adaptativa no grupo, os pressupostos tornam-se válidos e, assim, são ensinados para os novos grupos - a melhor forma de perceber, pensar e sentir, ou seja, de conviver com determinado problema e de solucioná-lo.

Ainda para o mesmo autor, a cultura organizacional pode ser aprendida a partir de três níveis: dos artefatos visíveis, dos valores que governam o comportamento das pessoas e dos pressupostos inconscientes. O nível dos artefatos visíveis se refere a tudo que é concreto e artificial, assim como vestuários, imóveis, documentos, padrões de comportamento. O nível dos valores que governam o comportamento das pessoas refere-se aos manifestos da cultura - idealizados e racionalizados. Esses valores são construtos que só podem ser observados a partir de técnicas que possibilitem a sua explicitação. Já o nível que se refere aos pressupostos inconscientes determina o tipo de pensamento, de percepção e de sentimento do que está ocorrendo em um grupo. A partir do momento em que um determinado valor se torna eficiente e eficaz na solução de problemas, este é incorporado pelo grupo e se torna inconsciente.

Rousseau (1990) acrescenta dois níveis formadores de cultura aos de Schein (1986): padrões de comportamento e normas comportamentais. Os primeiros estão 
relacionados aos mecanismos de tomada de decisão, coordenação e comunicação utilizados na resolução de conflitos, enquanto os segundos se referem às expectativas que a organização tem sobre como seus membros devem se comportar e interagir.

Hofstede, Neuijein, Ohayv e Sanders (1990) propuseram que a cultura organizacional seja composta por elementos que se manifestam por meio das práticas organizacionais que podem ser modificadas de forma planejada. Faz parte da cultura organizacional um elemento de sentimentos inconscientes e indiscutíveis, que não são observados diretamente e que modificam a própria lógica: os valores. Os rituais apresentam-se como atividades coletivas, desnecessárias do ponto de vista técnico, porém, indispensáveis socialmente. Os heróis estão associados às personalidades que se apresentam como modelo comportamental e que podem estar vivas ou mortas, serem reais ou imaginárias, mas que aparecem revestidas de prestígios. Os símbolos incluem os gestos, as palavras, os objetos com significados especiais para a organização.

De acordo com Hofstede (1998), são os valores dos fundadores, figuras representativas, que vão gerir as práticas organizacionais. Sem embargo, percebe-se que nem todos os membros de uma organização compartilham os mesmos valores, embora adotem as práticas quando se comprometem com a organização.

Diante do exposto, observa-se que os autores concordam que os valores organizacionais representam um forte componente formador da cultura organizacional, bem como que fatores como as normas comportamentais também são importantes. De acordo com Rousseau (1990), existem três tipos de cultura: construtiva, agressivodefensiva e passivo-defensiva, sendo essa última tida como estímulo convencional, de aprovação, de dependência e de evitação. A agressivo-defensiva refere-se às análises de oposição, de poder, competitivo e perfeccionista e, por sua vez, a construtiva reflete um estilo humanístico-encorajador, afiliativo, de realização e autoexpressão. 
Ferreira e Assmar (2008), no Instrumento Brasileiro para Avaliação de Cultura Organizacional (Ibaco), apresentam a avaliação dos aspectos comportamentais (Rousseau, 1990) e dos valores (Hofstede et al., 1990). O Ibaco estrutura-se em sete dimensões: valores de profissionalismo coorporativo; valores de rigidez na estrutura hierárquica; valores de profissionalismo competitivo e individual; valores associados à satisfação e ao bem-estar dos trabalhadores; práticas de integração externa; práticas de recompensa e treinamento; práticas de promoção do relacionamento.

Os valores de profissionalismo coorporativo estão relacionados à valorização dos trabalhadores que realizam suas tarefas com eficácia e competência. Os valores de rigidez na estrutura hierárquica refletem um sistema de autoridade centralizado e autoritário, que impede o crescimento profissional e o reconhecimento humano. Os valores de profissionalismo competitivo e individual priorizam a competência, o desempenho e a eficácia individual na realização das atividades, o que pode provocar comportamentos como o de passar por cima de tudo para alcançar os objetivos almejados. Os valores associados à satisfação e ao bem-estar dos trabalhadores visam o bem-estar, a satisfação e a motivação, o que leva à humanização no local de trabalho, gera prazer e sensação de agradabilidade. As práticas de integração externa voltam-se para o planejamento estratégico, a tomada de decisões e o atendimento ao cliente externo, focando os altos escalões da organização. As práticas de recompensa e treinamento dizem respeito aos exercícios acoplados ao cliente interno e aos sistemas de treinamento e recompensa adotados pela organização. As práticas de promoção do relacionamento são aquelas que promovem as relações interpessoais e a satisfação dos trabalhadores, o que favorece a coesão interna.

De acordo com Tamayo (2005), estudos realizados em diferentes países (Paschoal \& Soraggi, 2011; Schwartz, 1992, 1994; Tamayo \& Schwartz, 1993) mostram que os 
valores são estruturados em metas individuais. Conforme pesquisas desenvolvidas em diferentes países, há uma tipologia motivacional universal (Schwartz, 1994, 2012; Tamayo \& Schwartz, 1993), baseada nos valores das pessoas (Schwartz \& Bilsky, 1990).

Nesse sentido, Tamayo (2005) cita dez motivações, assim como suas respectivas metas (Tabela 1). Dessas metas, cinco se referem aos primeiros tipos motivacionais, relacionados apenas com a própria pessoa, assim como o prazer, o sucesso e o prestígio. Já as metas motivacionais de tradição, conformidade e benevolência satisfazem diretamente as metas relativas à família, ao grupo de referência e à sociedade. Por outro lado, os interesses próprios e dos outros são influenciados pelas metas universalismo e segurança.

Tabela 1. Metas Motivacionais

\begin{tabular}{ll}
\hline \multicolumn{1}{c}{ Motivação } & \multicolumn{1}{c}{ Metas Motivacionais } \\
\hline 1. Hedonismo & Prazer e gratificação sensual \\
2. Realização & O sucesso pessoal obtido, demonstração de competência \\
3. Poder social & Controle sobre pessoas e recursos, prestígio individual \\
4. Autodeterminação & Independência de pensamento, ação e opção individuais \\
5. Estimulação & Excitação, novidade, mudança e desafios individuais \\
6. Conformidade & Controle de impulsos e ações que, coletivos, podem violar normas sociais ou \\
& prejudicar os outros \\
7. Tradição & Respeito e aceitação dos ideais coletivos, costumes da sociedade \\
8. Benevolência & Promoção do bem-estar coletivo \\
9. Segurança & Ordem social, segurança familiar \\
10. Universalismo & Compreensão, tolerância, procura do bem-estar de todos na sociedade \\
\hline Fonte: Tamayo $(2005$, p. 179$)$.
\end{tabular}

No entanto, esses dez tipos expressam a estrutura de valores de uma pessoa, que se configura por conjuntos motivacionais, com metas específicas que parecem fazer parte de pessoas de todas as culturas. Assim, conforme Pereira, Camino e Costa (2004), um conjunto de valores surge em determinada sociedade condicionado às próprias tendências ideológicas dos grupos sociais. Tamayo (2005) destaca que a estrutura motivacional é dinâmica e que os seus componentes motivacionais se relacionam em diversas polaridades entre si. 
Para Tamayo (2000), as organizações se constituem como um lugar privilegiado, no qual os trabalhadores desenvolvem sua identidade profissional e é o ambiente social ao qual está exposto o trabalhador e que lhe proporciona realização pessoal, social e profissional. As necessidades, os valores pessoais e dos outros são determinados pelo que o indivíduo procura no seu trabalho, ou seja, os elementos biológicos e psicossociais são essenciais para a sobrevivência individual e do grupo. Assim, os princípios e as metas sociais e pessoais constituirão a valoração do que é bom e desejável para si e para a sociedade. Os valores, portanto, determinam as opções das pessoas, assim como as respostas emocionais dadas a tais opções. Nessa perspectiva, os gestores organizacionais sabem que não conseguirão atingir as metas organizacionais de produtividade e eficiência sem atender às metas fundamentais das pessoas que compõem o staff. Por isso, faz-se necessário que as metas organizacionais se associem às metas e motivações pessoais.

Nesse sentido, pode-se dizer que os valores são estruturados a partir de conhecimentos socialmente elaborados em sistemas amplamente compartilhados (Da Costa, 2000). Nessa perspectiva, Pereira et al. (2004) apontam que os sistemas de valores anunciam os conflitos ideológicos vivenciados pelas sociedades e direcionam a forma como as pessoas e a sociedade se comportam nos grupos sociais e se posicionam ideologicamente. Pautados nessa discussão, esses autores, a partir de várias investigações, desenvolveram o Questionário de Valores Pessoais (QVP), com o objetivo de avaliar os sistemas de valores, assim como a relação destes com as atitudes ideológicas em grupos sociais (Lima \& Camino, 1995; Pereira, Lima, \& Caminho, 2001). Esse instrumento foi utilizado no estudo dois para investigar os valores pessoais dos policiais militares.

Essas tendências ideológicas formadas pelos valores pessoais dos grupos estão organizadas em quatro sistemas com conteúdos diferentes: materialista, pós-materialista, religioso e hedonista (Pereira, Camino, \& Costa, 2004). O sistema materialista representa a 
ideologia da acumulação de riqueza e status social (Inglehart, 1994). O sistema pósmaterialista abrange as ideologias que enfatizam ideias mais abstratas, sendo composto pelo bem-estar social, pela autorrealização e pelo conhecimento (Inglehart, 1977). Considera-se que esse sistema é formado por três subsistemas: bem-estar social, bem-estar pessoal e bem-estar profissional (Pereira, Camino, \& Costa, 2004; Pereira, Camino, \& Costa, 2005; Pereira, Ribeiro, \& Cardoso, 2004; Pereira, Torres, \& Barros, 2004). O sistema religioso representa a concepção da obediência a regras religiosas, crenças e normas de comportamento (Schwartz, 1992). Por fim, o sistema hedonista enfatiza a busca do prazer, a emoção na vida e a valorização da sexualidade (Schwartz, 1992).

Com base na abordagem societal, os quatro sistemas são organizados em duas dimensões. A primeira delas compreende os sistemas materialista e pós-materialista (Inglehart, 1977; Pereira et al., 2005), enquanto a segunda se opõe ao sistema religioso e hedonista. Os valores materialistas correlacionam positivamente com o hedonista e contrapõem-se ao religioso; já o pós-materialista correlaciona-se positivamente com o valor religioso e é contrário ao hedonista.

Os valores pessoais e organizacionais são dois sistemas consolidados, que apresentam diferenças importantes, assim como características comuns aos dois sistemas (Tamayo, 1999). Enquanto os valores pessoais norteiam as atitudes e os comportamentos das pessoas (Porto \& Tamayo, 2007), os princípios e as metas, coletivas e compartilhadas no grupo, ou seja, de um grupo e de uma organização, se referem aos valores organizacionais (Tamayo, 1999). Os valores pessoais podem estar pautados em focos específicos que guiam a sua vida em geral, bem como na formação de estruturas interrelacionadas (Porto \& Tamayo, 2007). No entanto, quando o foco é o trabalho, as pessoas exibem uma estrutura de valores específica, mas elas estão relacionadas às estruturas sociais e organizacionais (Sagie \& Elizur, 1996). 
Ambas as categorias de valores, pessoais e organizacionais, se configuram em metas, estruturadas de forma a guiar a vida de pessoas, grupos e organizações. Desse modo, percebe-se que os valores organizacionais orientam tanto a vida organizacional, quanto os comportamentos dos trabalhadores, gestores e empregados. Dessa forma, os valores organizacionais sustentam as atitudes e motivam o trabalhador a obter metas e a alcançar seus objetivos. Esses valores são determinantes da convivência organizacional, expressos nas formas de julgar e avaliar comportamentos e eventos organizacionais e, portanto, influenciam diretamente no clima organizacional, assim como nas tomadas de decisões organizacionais. Pode-se dizer que, por meio do conhecimento dos valores de uma organização, é possível predizer como ela funciona e quais são os comportamentos organizacionais de seus membros (Tamayo, 1999).

Pode-se dizer que, conceitualmente, tanto os valores pessoais quanto os organizacionais apresentam os componentes motivacional, cognitivo, hierárquico e social. No entanto, os conflitos surgem a partir dos interesses do indivíduo e do grupo, afetando as bases de toda a organização e, por isso, muitas vezes são tidos como valores incompatíveis. Nesse sentido, surgem as teorias de integração dos indivíduos ao seu ambiente de trabalho, de forma a buscar a sua adaptação, acomodação, adequação, encaixe e correspondência. É como se os valores pessoais e organizacionais pudessem ser ajustados e adequados aos valores e interesses organizacionais (Tamayo, 1999).

Em pesquisa desenvolvida por Tamayo (2000), na qual ele comparou os valores individuais com os de uma organização, foi possível observar que os ambientes são regidos não só pelos valores e interesses opostos ao do trabalhador, mas também há uma prioridade diferencial, dada a determinados tipos de valores internalizados pela organização e pelo trabalhador. Além disso, esse autor buscou entender o que é comum na estrutura dos valores pessoais e dos valores organizacionais. Consequentemente, do ponto 
de vista teórico, existe uma base similar entre a estrutura dos valores pessoais e dos valores organizacionais, expressos em sua origem, desenvolvimento e função organizacional. Diante dos achados nesta pesquisa, Tamayo (2000) preconiza que:

1) É similar a origem dos valores organizacionais e pessoais e o que a origem dos valores organizacionais causa nas pessoas. A organização é composta por pessoas que, quando entram nela, já possuem, em sua estrutura, os sistemas de valores pessoais que expressam as metas que definem o que é bom para si, para os grupos e para a sociedade. Portanto, o que sustenta os valores organizacionais e pessoais são as motivações, que podem ser altamente semelhantes.

2) A partir das exigências internas e externas da organização, decorrentes das necessidades e das motivações de seus membros, os valores organizacionais se desenvolvem.

3) Valores são produzidos por toda organização. A partir das experiências dos membros organizacionais e das trocas coletivas realizadas pelas interações com a experiência e com os objetivos organizacionais criam os valores que servem para estabelecer e manter a identidade organizacional. Assim, os valores guiam a vida organizacional, motivam seus membros e definem o contexto favorável para o trabalho produtivo e para a vida organizacional, tanto no aspecto individual quanto coletivo.

As organizações enfrentam três exigências fundamentais:

a necessidade de compatibilizar os interesses individuais e os coletivos, uma vez que a relação entre indivíduo e grupo é inevitável; o estabelecimento de uma estrutura que garanta o alcance das metas e objetivos da organização; e o relacionamento entre a organização e o ambiente físico e social (Tamayo \& Borges, 2001, p. 345).

Os valores de uma organização podem explicar os fenômenos organizacionais a partir do momento em que eles sustentam respostas a problemas concretos de experiências 
que envolveram soluções bem-sucedidas no passado e orientaram a satisfação dessas necessidades. Assim, conforme Tamayo e Borges (2001, p. 343), os valores organizacionais são "princípios ou crenças, organizados hierarquicamente, relativos a condutas ou metas organizacionais desejáveis, que orientam a vida da organização e estão a serviço de interesses individuais, coletivos ou ambos".

Nessa perspectiva, Tamayo e Mendes (1999, p. 3) mostram que os valores "fazem parte de uma dialética de manutenção e de transformação dos comportamentos humanos pela socialização e aprendizagem permanentes, sendo, por isso, valiosos para as instituições que desejam modelar comportamentos em função de seus interesses”. Ao sustentar que os valores devem ser estudados em sua integralidade, Tamayo e Gondim (1996) argumentaram que os valores organizacionais possuem três componentes básicos: cognitivo, motivacional e de organização hierárquica. O componente cognitivo representa as respostas cognitivas prontas e privilegiadas a problemas organizacionais. O componente motivacional está expresso em interesses e metas fundamentais. $\mathrm{O}$ componente de organização hierárquica expressa as preferências por determinadas condutas, metas ou estratégias em detrimento de outras.

Em outro estudo, Tamayo (2004) propõe a estrutura de valores organizacionais composta por oito tipos motivacionais que se configuram enquanto fatores de realização, conformidade, domínio, bem-estar, tradição, prestígio, autonomia, preocupação com a coletividade. Esses fatores originam-se dos valores pessoais e possuem características comuns, assim como os componentes motivacionais e a função de orientar comportamentos.

De acordo com esse princípio, pode-se dizer que os fatores de valores organizacionais se associam à estrutura básica de valores pessoais proposta por Schwartz (1992, 2012) e que são agrupadas em dimensões básicas bipolares (Figura 1). 


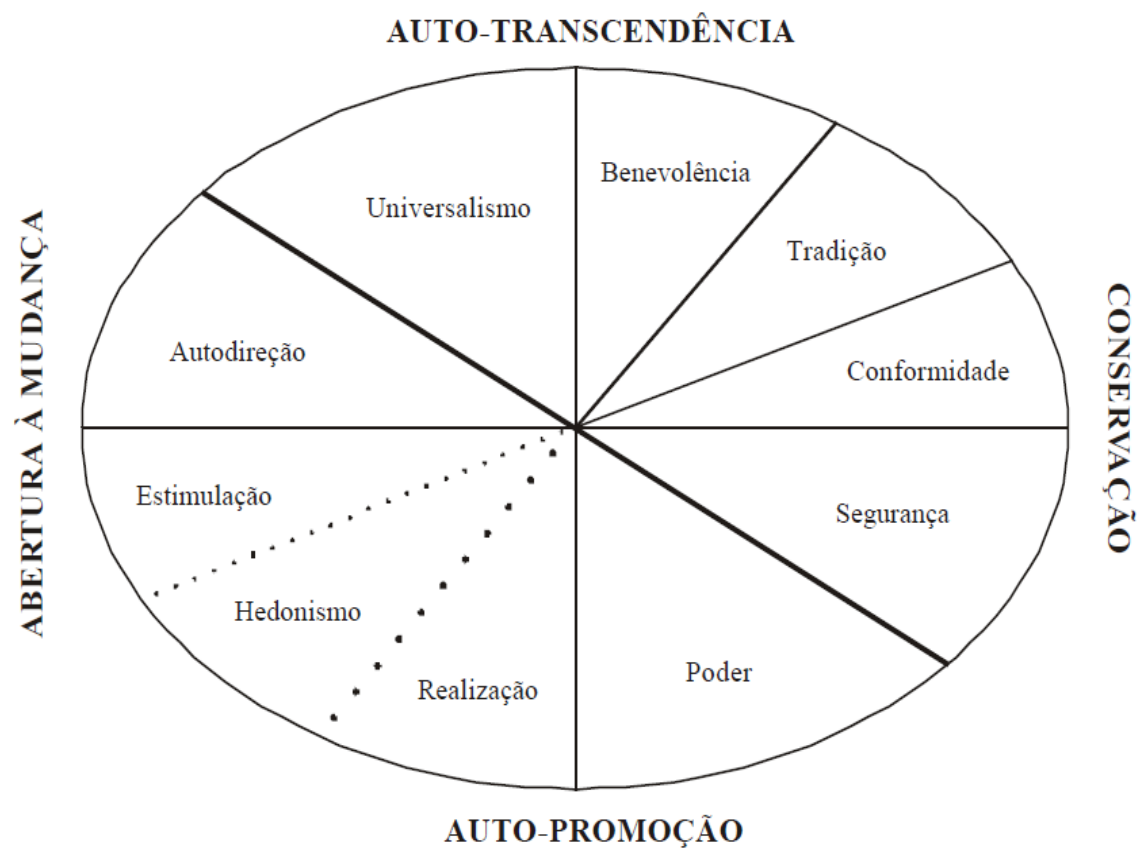

Figura 1. Estrutura Bidimensional dos Tipos Motivacionais. Fonte: Adaptado de Schwartz (1992, p. 14).

Conforme se pode ver na Figura 1, a dimensão conservação se opõe à abertura à mudança, assim como a autopromoção à autotranscedência. Logo, diz-se, em relação às dimensões: "conservação versus abertura à mudança" e "autopromoção versus autotranscedência". A dimensão conservação se opõe aos valores que enfatizam a independência de ação (abertura a mudanças), mantendo valores que se referem à manutenção de práticas tradicionais na busca pela estabilidade. Os valores organizacionais tradição e conformidade são opostos à autonomia (autodireção), e, respectivamente, pertencem às dimensões conservação e abertura à mudança (Oliveira \& Tamayo, 2004).

As dimensões autopromoção versus autotranscedência apresentam-se opostas, pois a primeira privilegia interesses individuais, mesmo que à custa de valores de outras pessoas, enquanto a segunda enfatiza valores de preocupação com o bem-estar dos outros e da natureza. Portanto, prestígio, domínio, realização e bem-estar são valores organizacionais que correspondem à autopromoção, enquanto a autotranscedência volta-se 
à preocupação com a coletividade. Nonaka e Takeuchi (1997) ressaltam que os valores relativos à abertura, mudança, autopromoção e preocupação com a coletividade estariam associados à capacidade de desenvolver-se a partir de conhecimentos, bem como adquirir condições que capacitam e ampliam os processos de conversão dos próprios valores.

Ressalta-se, aqui, conforme Pereira e Camino (1999) e Lins, Poeschi, Lima, Souza, e Pereira (2016), que conflitos podem existir tanto em relação às motivações individuais, como em relação às coletivas, pois os valores não se estabelecem somente a partir de representações cognitivas e conforme interesse e motivação individuais. Isto é, os valores têm pouco a ver com as necessidades, uma vez que estão relacionados, principalmente, a ideias sobre como a sociedade deve ser organizada (Deschamps \& Devos, 1993). Assim, não se deve confiar na divisão entre indivíduo e valores sociais, visto entender-se que todos os valores são sociais, já que são produzidos em interações sociais (Beattie, 1980; Lima, 1997) e, então, são largamente compartilhados pelos indivíduos (Maio, Olson, Allen, \& Bernard, 2001).

Percebe-se que é relevante desenvolver estudos sobre os valores organizacionais para que se fortaleçam as áreas de diagnóstico e de gestão organizacional. Conforme Deal e Kennedy (1998), com os estudos sobre os valores organizacionais torna-se possível apontar os valores que possibilitam definir a direção comum a ser seguida pelos trabalhadores, além de saber o que influencia os comportamentos organizacionais.

Nessa perspectiva, Tamayo (2000) afirmou que é possível compreender e identificar os valores organizacionais de duas formas: a primeira seria estudando os documentos oficiais de uma instituição/organização, que, em sua maioria, subsidiam as análises qualitativas; a segunda, seria entendendo a própria percepção dos colaboradores sobre os valores organizacionais. Já no trabalho de Tamayo (2008), ele acrescenta a 
existência de mais uma forma de conhecer os valores organizacionais, por meio dos valores individuais dos membros da organização.

A forma de avaliar os valores organizacionais a partir da percepção dos funcionários foi desenvolvida no Brasil por Oliveira e Tamayo (2004), Tamayo (1996), Tamayo e Gondim (1996) e Tamayo, Mendes e Paz (2000). A escala de Tamayo e Gondin (1996) é utilizada neste estudo. Esse instrumento (Escala de Valores Organizacionais EVO) foi construído por Tamayo e Gondim, em 1996, e avalia cinco dimensões dos valores organizacionais: eficácia/eficiência, interação no trabalho, gestão, inovação e respeito ao servidor (Tamayo, 2008).

Tomados em conjunto, considera-se, neste trabalho, que os valores pessoais são componentes dos valores organizacionais e estes, por sua vez, influenciam os comportamentos dos indivíduos que compõem a organização. Tamayo e Gondim (1996) explicam que os valores organizacionais constituem o núcleo da cultura organizacional. Dessa forma, as instituições militares influenciam não só as atitudes de seus membros, como também guiam as práticas ideológicas cotidianas, como, por exemplo, os mitos e as crenças sobre suicídio. 


\section{Capítulo 3}

\section{Justificativa e Objetivos do Estudo}

Em face do contínuo aumento nas taxas de suicídio, observadas nas últimas décadas, o tema tem sido abordado como um problema de saúde pública. Há um grande avanço na identificação de fatores de risco, que vão além dos transtornos mentais - tais como sexo, profissão, situação conjugal e idade (Bertolote, Santos, \& Botega, 2010; Ferreira \& Trichês, 2014; Ramos \& Falcão, 2011) - e podem auxiliar os profissionais de saúde e de segurança na identificação de uma pessoa suicida em potencial, permitindo o início de uma abordagem precoce que evite o desfecho letal.

Percebe-se que pesquisas com profissionais de segurança ainda são muito escassas, ainda que estudos que auxiliem o entendimento de fatores associados ao atendimento dos casos de suicídio sejam fundamentais para a constituição de políticas públicas de segurança e de saúde eficazes, voltadas para a realidade local. A prevenção ao suicídio deve envolver desde medidas que melhorem a qualidade de vida dos grupos mais vulneráveis, tais como apoio familiar, suporte social e renda adequada, até a detecção e o tratamento precoce, humanizado e interdisciplinar aos possíveis transtornos e fatores de risco que possam levar ao suicídio.

Ainda no que tange à justificativa, o presente estudo poderá contribuir com a elaboração de estratégias de prevenção ao suicídio e com o acolhimento mais humanizado a pessoas nessas condições. Ademais, a identificação do impacto dos valores pessoais e organizacionais nos mitos e crenças de profissionais de segurança será importante para entender como o contexto organizacional pode influenciar as crenças de seus membros e, então, suas atitudes diante das vítimas. 
As teorias e os conceitos apresentados nos capítulos um e dois fundamentam o objetivo principal desta tese, que é investigar mitos e crenças sobre suicídio nos profissionais de segurança e sua associação com as variáveis valores pessoais e valores organizacionais. Para atender a esse objetivo, esta pesquisa foi desenvolvida em dois estudos, cujos objetivos são apresentados a seguir.

\subsection{Objetivo do Estudo 1}

Proceder à análise fatorial exploratória da Escala de Mitos e Crenças sobre o Suicídio (EMCS). Esse instrumento serviu de base para alcançar o objetivo geral do segundo estudo, o principal da presente tese.

\subsection{Objetivos do Estudo 2}

Geral: Identificar mitos e crenças de profissionais militares (PM e CBM) que atendem chamados de socorro em casos de suicídio, bem como analisar preditores de mitos e crenças sobre o suicídio entre valores pessoais e organizacionais.

Específicos: Compreender a associação entre variáveis pessoais, como religião, nível hierárquico, de instrução, gênero, idade, situação conjugal dos profissionais e as crenças e os mitos sobre o suicídio, nas duas corporações militares de Goiânia, Goiás.

A investigação desses objetivos decorre das seguintes hipóteses:

Hipótese 1. Em estudos desenvolvidos por Freemouw et al. (1990), Freitas e Borges (2014), Osafo et al. (2011) e Portela (2012), foi revelado que muitos profissionais possuem mitos e crenças a respeito do fato de que as pessoas que tentam suicídio não conseguem resolver seus problemas, têm problemas mentais, querem apenas chamar a 
atenção e são covardes. Partindo desse pressuposto, tem-se como hipótese que os profissionais que trabalham com pessoas que tentam o suicídio ou que o praticam desenvolverão mitos e crenças acerca de que elas não conseguem resolver seus problemas, têm problemas mentais, querem chamar a atenção e são covardes.

Hipótese 2. Xausa (1986) aponta que o homem é impulsionado pelos instintos, atraído pelo sentido da vida e pelos valores, que são mobilizadores das forças vitais. Assim, as pessoas buscam suas respostas de vivência de valores a partir dos meios sociais, sendo eles a base para as relações sociais. Tem-se como hipótese, a partir desses pressupostos, que variáveis pessoais como religião, nível hierárquico e situação conjugal dos profissionais influenciarão mitos e crenças sobre o suicídio nas duas corporações militares de Goiás (Botega et al., 2006).

Hipótese 3. Destaca-se que o trabalho exerce importante papel na construção da subjetividade humana, tornando-se elemento constitutivo da saúde mental: o trabalho é o espaço onde o homem cria e recria para sobreviver e realizar-se, caracterizando-se como fonte de prazer e sofrimento. Partindo desse princípio, considera-se o profissional de atendimento de emergências como sujeito que sente, sofre e se afeta. Dessa forma, entende-se que esse profissional é influenciado por seus valores pessoais e pelos valores da corporação. Nessa perspectiva, hipotetiza-se que os valores pessoais e organizacionais predizem os mitos e as crenças sobre o suicídio, o que pode também influenciar suas atitudes em relação ao atendimento de emergência. 


\section{Capítulo 4}

\section{Estudo 1 - Análise Fatorial Exploratória da Escala de Mitos e Crenças sobre o Suicídio (EMCS)}

O estudo sobre mitos e crenças sobre o suicídio na população de estudantes universitários dos cursos de Medicina, Enfermagem e Psicologia teve como objetivo principal a validação da escala a partir da análise de sua estrutura fatorial. Os conceitos e definições que o respaldam foram apresentados no capítulo 1 da tese. Assim, aqui se restringe a apresentar as seções método, resultados e considerações finais.

\subsection{Método}

\subsubsection{Participantes}

Participaram do estudo 493 indivíduos, com média de idade de 22 anos ( $\mathrm{DP}=5,8)$, estudantes de ensino superior de uma universidade privada de Goiânia. A universidade foi escolhida pelo critério de tempo de consolidação dos cursos, tendo o de Enfermagem 75 anos, o de Psicologia 43 anos e o de Medicina 11 anos de existência. A escolha por esses cursos deu-se, também, pelo fato de os estudantes serem possíveis profissionais atuantes no socorro a vítimas de TAE e por terem inserção na área de saúde.

O critério de inclusão dos participantes foi estar matriculado nos cursos especificados. Os critérios de exclusão dos participantes foram: não consentir em participar do estudo e fazer parte de outro curso que não os mencionados. 


\subsubsection{Instrumentos}

A escala validada para análise dos mitos e crenças sobre suicídio é um instrumento elaborado pelo Núcleo de Intervenção em Crise e Prevenção do Suicídio, do Departamento de Psicologia Clínica, pertencente ao Instituto de Psicologia da Universidade de Brasília, coordenado pelo Professor Dr. Marcelo Tavares (PCL/IP/UnB), com base no relato de profissionais da área de saúde atuantes em hospitais do Distrito Federal e em participantes de seminários de estudos sobre suicídio.

O gabarito da EMCS foi elaborado pela equipe do laboratório citado, a partir da literatura científica sobre o tema, bem como da experiência profissional dos seus integrantes a respeito do tema suicídio, sendo de responsabilidade dessa equipe a classificação das afirmações em verdadeiras ou falsas. A versão inicial continha 62 afirmações em formato dicotômico falso e verdadeiro, escolhido para favorecer a inteligibilidade da escala e proporcionar melhor posicionamento do participante sobre o comportamento de pessoas que tentam ou efetivam o ato suicida.

Foi utilizado, neste estudo, também, um questionário sociodemográfico, visando obter dados sobre sexo, idade, curso de graduação, situação conjugal e religião dos participantes.

\subsubsection{Procedimentos}

\subsubsection{Coleta de dados}

Para a realização desta pesquisa, o projeto foi submetido ao Comitê de Ética em Pesquisa da Pontifícia Universidade Católica de Goiás (PUC-Goiás). Foi aprovado sob o número CAAE: 54798416.9.0000.0037.

Após a aprovação pelo Comitê de Ética, fez-se contato com a coordenação de cada curso para solicitar autorização para entrar nas salas de aula e realizar a coleta de dados. 
Em seguida, foi estabelecida a distribuição de salas e horários para planejamento da aplicação. Para garantir a validade externa, foi utilizada amostragem estratificada, objetivando a representatividade dos períodos por curso. Com o levantamento das salas nas secretarias dos cursos, calculou-se a amostra aleatória simples, identificando-se de quatro a cinco turmas dependendo do curso. Essa amostra pode ser considerada representativa, uma vez que abrangeu grande parcela de cada curso, com erro estimado de $6 \%$.

Depois da obtenção da autorização dos professores, foi realizado o agendamento dos dias e horários da aplicação. Após a apresentação dos objetivos do estudo e da assinatura do Termo de Consentimento Livre e Esclarecido (TCLE) pelos participantes, conforme orientações do Comitê de Ética em Pesquisa, estes foram abordados coletivamente, nas salas de aula, após autorização do professor. A equipe de pesquisadores dirigia-se para as salas, a fim de repassar as informações sobre o projeto de pesquisa aos alunos, que foram informados sobre a participação voluntária e o consentimento. Os alunos receberam o já informado Termo em duas vias, assinadas pelos pesquisadores e testemunhas, e ficaram de posse de uma delas.

\subsubsection{Análise de dados}

Foi utilizado o Statistical Package for the Social Sciences (SPSS), versão 20.0. Inicialmente, foi feita a análise de dados perdidos e aqueles casos em que havia itens em branco ou respostas iguais aos itens (todas as marcações na mesma escala de resposta) foram excluídos.

Em seguida, foi realizada a análise de pressupostos para análise fatorial e os dados foram analisados, primeiramente, por técnicas estatísticas descritivas. Em seguida, buscouse verificar a fatorabilidade da matriz e identificar quantos fatores formavam a estrutura fatorial da escala em análise. 
Foi realizada uma análise fatorial a partir do método de extração principal axis factoring (AFE), que identifica se uma variável particular (item) pode contribuir com determinado fator. Foi aplicado o método de rotação ortogonal varimax, técnica que tenta maximizar a dispersão das cargas nos fatores, buscando agregar um menor número de variáveis sobre cada um.

Também foi verificada a confiabilidade da solução fatorial, por meio do indicador alpha de Cronbach, que aponta se a escala reflete o construto que está medindo. Valores acima de 0,70 são bons indicadores dessa medida (Cronbach, 1996; Field, 2009; Hair, Black, Babin, Anderson, \& Tatham, 2009; Pasquali, 2003).

\subsection{Resultados}

\subsubsection{Caracterização da amostra}

A amostra válida foi composta por 493 estudantes de uma universidade privada do estado de Goiás. Participaram, inicialmente, 520 alunos, no entanto, 27 foram excluídos porque deixaram itens em branco ou os responderam igualmente. Nas variáveis sociodemográficas, dados perdidos foram identificados, mas essas omissões não levaram à exclusão de casos.

Sobre a distribuição dos participantes nos cursos, 37\% (n=161) cursavam Medicina, 43,4\% ( $n=189)$ Psicologia e 19,5\% ( $n=85)$ Enfermagem. Foram totalizados 435 participantes, que informaram seus cursos de graduação, pois 58 não responderam essa informação. Os participantes eram, em sua maioria, do sexo feminino, 79,6\% (n=336) e 20,4\% ( $\mathrm{n}=86)$ do masculino. A média de idade foi de 22 anos ( $\mathrm{DP}=5,8$, mediana=21 anos, máximo=64 anos; mínimo=16 anos). Quanto à raça, $422(85,6 \%)$ participantes responderam e 47,2\% $(n=199)$ deles se declararam brancos, 41,5\% $(n=175)$ pardos, 5,5\% 
$(\mathrm{n}=23)$ amarelos, 5,2\% $\quad(\mathrm{n}=22)$ pretos, $0,2 \% \quad(\mathrm{n}=1)$ indígenas e $0,5 \%$ outras não especificadas $(n=2)$.

Os participantes informaram, em sua maioria, $83 \%(n=351)$, serem solteiros, $9,2 \%$ $(n=39)$ se declararam casados, 2,4\% $(n=10)$ divorciados e 5,4\% $(n=23)$ em outras situações conjugais. A maior parte deles $(n=200 ; 47,8 \%)$ afirmou ser da religião católica, 21,3\% $(n=89)$ informaram serem protestantes/evangélicos e 30,9\% (n=129) não especificaram sua vinculação religiosa. A média da autoavaliação sobre a importância da religião na vida dos participantes foi de 7,16 (n=397; DP=3, mediana=8, mínimo=0 e máximo=10).

\subsubsection{Análise da estrutura fatorial}

A análise para avaliar os pressupostos que favorecem a utilização da análise fatorial exploratória (AFE) indicou que os resultados da matriz eram favoráveis para extrair os fatores dos itens $(\mathrm{KMO}=0,82$; Teste de Esfericidade de Bartllet $=5857,625 ; \mathrm{p}<0,001)$.

Em seguida, por meio da AFE, os dados foram rodados sem fixação de fatores e sem rotação. Os resultados apresentaram comunalidades de 0,488 a 0,740. Ao analisar o teste Scree de Cattell, que avalia os fatores com base no critério de autovalores, observouse que esse instrumento de medidas apresentava 21 fatores com autovalores superiores a 1 (de 1,004 a 9,112), ilustrando uma estrutura multifatorial. Porém, quando se analisa o gráfico do scree plot, observa-se que há uma mudança forte na direção da curva para dois fatores com autovalores acima de $3(3,254$ e 9,112), ilustrando uma estrutura bifatorial. Conforme Laros (2012), essa mudança no gráfico, momento em que os pontos que ficam acima da reta representam os fatores triviais, é essencial para que se extraia o número de fatores de forma correta (Figura 2). 


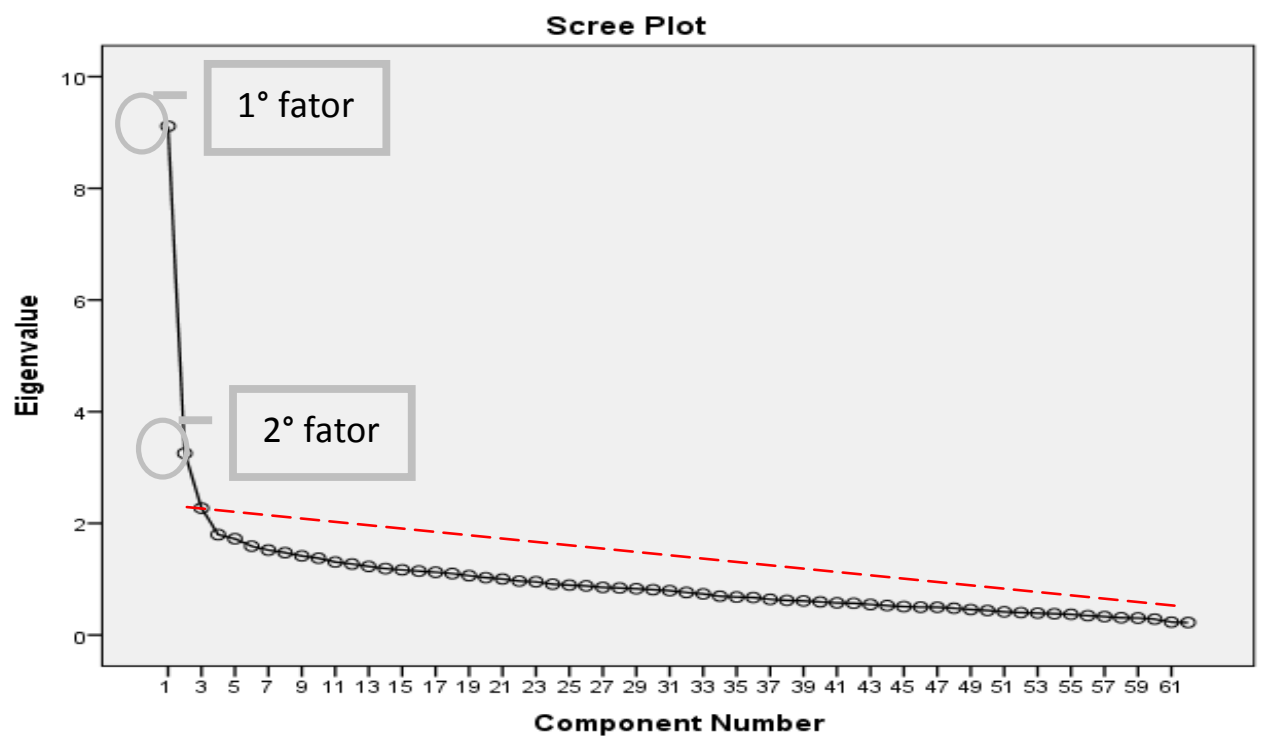

Figura 2. Gráfico Representativo dos Autovalores do Scree Plot para os Dados da Escala de Mitos e Crenças sobre Suicídio, Mostrando o Ponto que Separa os Fatores Triviais dos Não Triviais.

Fonte: Laros (2012).

Diante da determinação de que existem dois fatores nesse instrumento de medida, realizou-se a análise fatorial exploratória fixando dois fatores. A princípio, foi realizada a análise com rotação oblíqua, mas observou-se que a rotação varimax era mais adequada, pois os fatores eram independentes. Esses resultados confirmaram a existência de dois fatores com autovalores superiores a $3(3,254$ e 9,112). O primeiro fator possuía 32 itens, que explicavam 14,697\% da variância $(\alpha=0,87)$, enquanto o segundo fator tinha 16 itens, que explicavam 5,248\% da variabilidade $(\alpha=0,44)$. Foram excluídos 14 itens da escala, pois eles não se agruparam nos dois fatores identificados. Com as análises de confiabilidade, observou-se que somente o primeiro fator apresentou o alpha de Cronbach confiável $(\alpha \geq 0,70)$.

Optou-se por proceder à extração de um fator, tendo em vista o valor baixo do alpha de Cronbach do segundo fator. Procedeu-se novamente à análise fatorial e à análise do alpha de Cronbach, considerando a EMCS unifatorial. A Tabela 2 mostra que a análise resultou na exclusão de 30 itens, que não atingiram cargas fatoriais acima de 0,30 (itens: 1 , $6,12,14,16,19,20,22,24,25,27,28,35,40,42,43,44,45,47,48,49,50,51,54,56$, 
57, 58, 59, 60, 62). Assim, a versão inicial era composta por 62 itens e a versão final ficou

com 32 itens. $\mathrm{O}$ índice de confiabilidade alpha de Cronbach resultou em 0,87, podendo ser

considerado confiável.

Tabela 2. Cargas fatoriais, Variância Explicada e Fidedignidade da Escala de Mitos e Crenças sobre o Suicídio.

\begin{tabular}{|c|c|}
\hline Itens & $\begin{array}{l}\text { Cargas } \\
\text { fatoriais }\end{array}$ \\
\hline 39. Só "loucos" cometem suicídio. & 0,736 \\
\hline 29. Só vai atrapalhar dar muita atenção a quem faz uma tentativa de suicídio. & 0,707 \\
\hline 31. Se ele está falando sobre suas ideias suicidas, isso quer dizer que ele está fora de risco. & 0,680 \\
\hline 38. Se eu der ouvidos a um suicida, ele pode se matar. & 0,620 \\
\hline 33. Se um paciente melhorou rapidamente, ele está fora de risco. Posso ficar tranquilo. & 0,618 \\
\hline 8. As pessoas que ameaçam, não se matam. & 0,603 \\
\hline 23. Sugerir formas de se matar para um suicida não representa um perigo real. & 0,589 \\
\hline 21. Quem tem raiva do suicida tem razão de lhe dar o troco & 0,584 \\
\hline 46. A depressão é um diagnóstico óbvio, fácil de ser percebido. & 0,570 \\
\hline 37. Uma pessoa em risco, para confiar, precisa se sentir ouvida e respeitada. & 0,558 \\
\hline $\begin{array}{l}\text { 32. Quem faz uma tentativa de suicídio para chamar atenção não merece crédito, só vai reforçar } \\
\text { o que ele fez. }\end{array}$ & 0,552 \\
\hline 41. Quem não tem transtorno mental, não se mata. & 0,543 \\
\hline 34. Quando a gente fala de suicídio, só estamos dando mais força para o comportamento. & 0,534 \\
\hline 61. É preciso ter sangue frio para trabalhar com um paciente suicida. & 0,515 \\
\hline 9. Quem realmente quer se matar, não avisa, se mata da primeira vez. & 0,491 \\
\hline 3. A tentativa de suicídio representa uma vontade de aparecer, de chamar a atenção. & 0,488 \\
\hline 7. A tendência suicida é hereditária, passa de geração em geração. & 0,488 \\
\hline 36. É preciso ter calma e paciência para ajudar uma pessoa que fez uma tentativa. & 0,484 \\
\hline 15. Existem pessoas em risco que não podem ser deixadas sozinhas. & 0,445 \\
\hline 18. Suicídio é um ato de covardia. & 0,439 \\
\hline 4. A tentativa de suicídio é uma manipulação. & 0,436 \\
\hline 10. Ele tomou só aspirina. Na verdade, não queria morrer. & 0,433 \\
\hline 2. O impulso suicida é agudo e passageiro. & 0,405 \\
\hline 30. Falar sobre suicídio com pessoas deprimidas pode estimulá-las a uma tentativa. & 0,386 \\
\hline 5. Uma vez suicida, a pessoa será sempre suicida. & 0,375 \\
\hline $\begin{array}{l}\text { 55. Quem tem ideação ou outros comportamentos suicidas tem maior risco de morrer por } \\
\text { qualquer outra causa (por problemas de saúde, homicídio ou acidentes). }\end{array}$ & $-0,372$ \\
\hline $\begin{array}{l}\text { 53. O desejo de morte ou comportamento de risco de suicídio geralmente é resultado de um } \\
\text { longo e silencioso processo de sofrimento, que poderia ter sido relatado ou observado } \\
\text { precocemente. }\end{array}$ & 0,345 \\
\hline $\begin{array}{l}\text { 52. Conflitos, perdas e separações são os eventos que mais frequentemente antecedem uma } \\
\text { tentativa de suicídio. }\end{array}$ & 0,339 \\
\hline 26. O desespero é um sentimento comum em quem faz uma tentativa de suicídio. & 0,332 \\
\hline 13. Via de regra, é mais seguro pensar que quem tenta suicídio uma vez, tentará outras. & 0,326 \\
\hline 17. Suicídio é um ato de coragem. & 0,323 \\
\hline 11. A tentativa de suicídio representa um pedido desesperado de ajuda. & 0,318 \\
\hline
\end{tabular}

Nota: Variância explicada: 14,697\%; alpha de Cronbach: 0,87.

Diante dos dados obtidos na análise de consistência interna, considerou-se que a Escala de Mitos e Crenças sobre Suicídio é válida e fidedigna para medir aquilo que se propõe. Ressalta-se que seu formato unifatorial foi o mais indicado na validação estatística 
realizada por meio da análise fatorial (AFE). Como a escala é dicotômica, antes de se iniciar as análises de dados as variáveis foram transformadas em variáveis dummies $(0=$ falsa e $1=$ verdadeira $)$.

Destaca-se, como assinalado no método, que foi elaborado um gabarito, baseado na literatura específica sobre o suicídio e na experiência de profissionais que atuam na área, além de terem sido estabelecidos critérios para a correção das respostas (Tabela 3) tidas como verdadeiras e falsas. Estes apontam que 10 itens devem ser considerados verdadeiros e 22 falsos.

Tabela 3. Itens da Escala de Mitos e Crenças sobre Suicídio, após Validação. Itens

3. Via de regra, é mais seguro pensar que quem tenta suicídio uma vez, tentará outras.

5. É preciso ter calma e paciência para ajudar uma pessoa que fez uma tentativa. V

9. O desejo de morte ou comportamento de risco de suicídio geralmente é resultado de um longo e silencioso processo de sofrimento, que poderia ter sido relatado ou observado precocemente.

11. A tentativa de suicídio representa um pedido desesperado de ajuda.

13. Existem pessoas em risco que não podem ser deixadas sozinhas.

15. Quem tem ideação ou outros comportamentos suicidas tem mais risco de morrer por qualquer outra causa (por problemas de saúde, homicídio ou acidentes).

18. O desespero é um sentimento comum em quem faz uma tentativa de suicídio.

25. Uma pessoa em risco, para confiar, precisa se sentir ouvida e respeitada.

28. A depressão é um diagnóstico óbvio, fácil de ser percebido.

30. Conflitos, perdas e separações são os eventos que mais frequentemente antecedem uma tentativa de suicídio.

1. O impulso suicida é agudo e passageiro.

2. A tentativa de suicídio representa uma vontade de aparecer, de chamar a atenção.

4. A tentativa de suicídio é uma manipulação.

6. Uma vez suicida, a pessoa será sempre suicida.

7. A tendência suicida é hereditária, passa de geração em geração.

8. As pessoas que ameaçam, não se matam.

10. Quem realmente quer se matar, não avisa, se mata da primeira vez.

12. Ele tomou só aspirina. Na verdade, não queria morrer.

14. Suicídio é um ato de coragem.

16. Quem tem raiva do suicida tem razão de lhe dar o troco.

17. Sugerir formas de se matar para um suicida não representa um perigo real.

19. Só vai atrapalhar dar muita atenção a quem faz uma tentativa de suicídio.

20. Falar sobre suicídio com pessoas deprimidas pode estimulá-las a uma tentativa.

21. Se ele está falando sobre suas ideias suicidas, isso quer dizer que ele está fora de risco.

22. Quem faz uma tentativa de suicídio para chamar atenção não merece crédito, só vai reforçar o que ele fez.

23. Se um paciente melhorou rapidamente, ele está fora de risco. Posso ficar tranquilo.

24. Quando a gente fala de suicídio, só estamos dando mais força para o comportamento.

26. Se eu der ouvidos a um suicida, ele pode se matar.

27. Só "loucos" cometem suicídio.

29. Quem não tem transtorno mental, não se mata.

31. Suicídio é um ato de covardia.

32. É preciso ter sangue frio para trabalhar com um paciente suicida.

Gabarito

$\mathrm{V}$

V

$\mathrm{V}$

V

V

$\mathrm{V}$

$\mathrm{V}$

V

F

F

F

F

F

$\mathrm{F}$

F

F

$\mathrm{F}$

$\mathrm{F}$

F

F

$\mathrm{F}$

F

Nota. Todos os itens foram elaborados pelo prof. Dr. Marcelo Tavares (PCL/IP/UnB), com base no relato de profissionais da área de saúde atuantes em hospitais do Distrito Federal e em participantes de seminários de estudo sobre suicídio. 


\subsection{Considerações finais}

Tomados em conjunto, os resultados apontam que a Escala de Mitos e Crenças sobre o Suicídio (EMCS), com 32 itens, apresenta fidedignidade e consistência interna satisfatórias, de forma que esse instrumento é válido e preciso para avaliar o construto em questão, não obstante o reduzido percentual de variância explicada.

Por outro lado, deve-se considerar que a escolha dessa população para validação da EMCS pode ter ocasionado alguns vieses, visto que são estudantes muito jovens e que não têm experiência profissional com a temática em questão, aspecto divergente quando comparado aos profissionais do estudo subsequente, que são atuantes no mercado de trabalho no atendimento de emergências e situações de risco. 


\section{Capítulo 5}

\section{Estudo 2 - Valores Pessoais e Organizacionais Relacionados a Mitos e Crenças sobre o Suicídio: Visão de Profisssionais de Segurança}

Este estudo caracteriza-se como uma pesquisa observacional, uma vez que o pesquisador não interfere no estudo, correlacional, pois possibilita explorar as relações entre as variáveis, e transversal, por avaliar a situação ou o fenômeno em um momento não definido, apenas representado pela presença de variáveis avaliadas em um corte instantâneo que se faz da população (Hochman, Nahas, Oliveira Filho, \& Ferreira, 2005). Entende-se por mitos uma espécie de crença inconsciente ou uma atitude que, em razão de ter sido aceita por várias gerações de uma família ou grupo social, perpetua-se na determinação de suas condutas (Pincus \& Dare, 1981). A crença pode aparecer sob a palavra pensamento, representação, orientações cognitivas, teorias implícitas, saberes, além de valores, expectativas, perspectivas e atitudes. Enfim, são categorias vistas como parte da cultura do indivíduo, transformadas em pano de fundo do contexto no qual ele toma decisões diante de situações específicas, definindo tanto o seu pensamento quanto a sua ação.

Este estudo teve por objetivo principal identificar mitos e crenças que profissionais militares (PM e CBM) apresentavam sobre o suicídio, bem como pesquisar preditores de mitos e crenças entre valores pessoais e organizacionais.

Como objetivos específicos, investigou-se a relação entre variáveis pessoais (religião, idade, gênero, nível hierárquico e situação conjugal dos profissionais) com as crenças e os mitos sobre o suicídio, em ambas as corporações militares da cidade de Goiânia. 


\subsection{Método}

\subsubsection{Participantes}

Participou deste estudo uma amostra representativa de profissionais atuantes no serviço de resgate pré-hospitalar e primeiros socorros a vítimas de suicídio. Esses grupos de profissionais foram selecionados na Polícia Militar (PM) e no Corpo de Bombeiros Militar (CBM), na cidade de Goiânia (GO).

Os critérios de cálculo da amostra estão descritos na fórmula proposta por Richardson, Peres, Wanderley, Correia e Peres (1999), de forma a atingir a representatividade da população da pesquisa (Figura 3). Os participantes constituíram uma amostra de conveniência.

\begin{tabular}{|c|c|}
\hline $\begin{array}{l}\text { Fórmula: } \\
\mathrm{n}=\frac{\left(\sigma^{2} * \mathrm{p}^{*} \mathrm{q} * \mathrm{~N}\right)}{\left(\mathrm{E}^{2} *(\mathrm{~N}-1)\right)+\left(\sigma^{2} * \mathrm{p} * \mathrm{q}\right)}\end{array}$ & $\begin{array}{l}\text { Em que: } \\
\mathrm{n}=\text { tamanho da amostra; } \\
\mathrm{N}=\text { tamanho da população } \\
\sigma=\text { nível de confiança }(95 \% ; 1,96) \text { (Fonseca \& } \\
\text { Martins, 1996, p. 178) } \\
\mathrm{p}=\text { proporção das características pesquisadas no } \\
\text { universo }(\mathrm{p}=0,50) \text { (Fonseca \& Martins, } 1996, \mathrm{p} .181) \\
\mathrm{q}=\text { proporção do universo que não possui as } \\
\text { características pesquisadas }(1-\mathrm{p}) \\
\mathrm{E}^{2}=\text { erro de estimação permitido }(5 \% ; \mathrm{E}=0,05)\end{array}$ \\
\hline
\end{tabular}

Figura 3. Cálculo da Amostra Pesquisada neste Estudo.

Fonte: Richardson, Peres, Wanderley, Correia e Peres (1999)

Como a população de policiais militares na cidade de Goiânia é de 1.582 membros e a de CBM é de 393, a amostra representativa para os dois segmentos, juntos, é de 474 sujeitos.

Como critério de inclusão, o profissional tinha de atuar na área de atendimento emergencial: resgate hospitalar (CBM); atividades operacionais de atendimento - viatura (PM), bem como consentir em participar do estudo mediante assinatura do TCLE. Como 
critério de exclusão, foram considerados os profissionais que realizavam apenas atividades administrativas e que não estiveram envolvidos em ações de emergência.

\subsubsection{Instrumentos}

Foram utilizados, na pesquisa, quatro instrumentos: Escala de Mitos e Crenças sobre Suicídio (EMCS); Questionário Psicossocial de Valores - QPV-24; Escala de Valores Organizacionais (EVO); e um questionário para coleta de dados sociodemográficos.

A Escala de Mitos e Crenças sobre Suicídio (EMCS) foi construída e validada para o presente estudo, apresentada no capítulo 4 desta tese. A EMCS possui 32 itens, é dicotômica (escala de resposta com duas opções: afirmativa falsa ou verdadeira) e unifatorial, com alpha de Cronbach igual a 0,87, o que indica que esse instrumento é válido para avaliar o que se pretende mensurar.

O Questionário Psicossocial de Valores (QPV-24) foi construído e validado por Lins et al. (2016). Em seu modelo original, esse instrumento de medidas possui 24 itens sobre valores pessoais que avaliam quatro sistemas de valores: materialistas, hedonistas, religiosos e pós-materialistas. Estes sistemas eram compostos por subsistemas. O sistema materialista abarca os itens referentes à autoridade, ao lucro, à riqueza e ao status. Os itens que se referem ao prazer, à sensualidade, à sexualidade e a uma vida excitante formam o sistema hedonista. $\mathrm{O}$ sistema religioso é formado pelos itens relativos à obediência às leis de Deus, religiosidade, salvação da alma e temor a Deus. O sistema pós-materialista é composto de três subsistemas: bem-estar social, bem-estar individual e bem-estar profissional. O subsistema bem-estar social é composto pelos itens que abarcam fraternidade, igualdade, justiça social e liberdade. Os itens que se referem à alegria, amor, autorrealização e conforto formam o subsistema bem-estar individual. E o subsistema 
bem-estar profissional é formado pelo grupo de itens competência, dedicação ao trabalho, realização profissional e responsabilidade. Os índices de consistência interna dos quatro fatores (pós-materialista, $\alpha=0,80$; hedonista, $\alpha=0,80$; materialista, $\alpha=0,67$; e sistemas religiosos, $\alpha=0,78)$ foram satisfatórios. Essa escala varia de zero a dez e avalia o grau de importância para a construção de uma sociedade ideal. Para confirmar os índices psicométricos de validação neste estudo, foram realizados novamente os cálculos referente à análise fatorial, por causa da especificidade do grupo de militares. Assim, foram considerados, para as análises subsequentes, os cálculos comparativos dos resultados deste estudo.

A Escala de Valores Organizacionais (EVO) foi validada para o Brasil por Tamayo e Gondin, em 1996, e republicada por Tamayo, em 2008. Esse instrumento avalia, em uma escala de -1 a 7, o grau de importância que o valor organizacional tem para a organização: o valor -1 indica os valores opostos aos princípios apresentados pela organização e o valor 7 indica o maior grau de importância desse valor para guiar os princípios da organização. A EVO é constituída por um perfil de escores composto de cinco fatores que explicam 52,8\% da variância explicada: eficácia/eficiência, interação no trabalho, gestão, inovação e respeito ao emprego. O fator eficácia/eficiência é composto por nove valores: eficácia, eficiência, qualidade, produtividade, comprometimento, planejamento, pontualidade, competência, e dedicação $(\alpha=0,91)$. Um escore alto nesse fator indica que a instituição enfatiza a produtividade, a eficiência, a eficácia e os outros valores que compõem o fator. O segundo fator, interação no trabalho, é composto por 10 itens: abertura, coleguismo, amizade, cooperação, sociabilidade, flexibilidade $(\alpha=0,90)$. Um escore alto indica que os colaboradores consideram que a cultura da empresa valoriza a interação positiva no trabalho. O terceiro fator, gestão, é composto pelos valores tradição, hierarquia, obediência, fiscalização, supervisão, postura profissional e organização (gestão de tipo 
tradicional e hierárquico $)(\alpha=0,84)$. Escore alto nesse fator indica que os colaboradores percebem a instituição como tradicional, hierárquica e baseada na supervisão dos trabalhos. O quarto fator, inovação, é constituído por quatro valores: pesquisa, integração interinstitucional, modernização dos recursos materiais e probidade $(\alpha=0,70)$. Um escore alto significa que o trabalhador vê a instituição preocupada com inovação. Por fim, o fator respeito ao empregado é constituído por oito valores: respeito, reconhecimento, qualificação dos recursos humanos, polidez, honestidade, plano de carreira, harmonia e justiça $(\alpha=0,90)$. Um escore alto indica que os colaboradores percebem a valorização e o respeito com eles mesmos. De acordo com Tamayo e Gondim (1996), considera-se, para correção da EVO, que ela não possui um escore único, ou seja, ela possui um perfil de escores composto pelos cinco fatores. Para calcular os escores de cada um é necessário fazer a média aritmética dos itens que compõem cada fator.

O questionário sociodemográfico foi estruturado com itens que levantaram informações sobre sexo, idade, curso de graduação, situação conjugal, cargo, instituição de lotação e religião, além de três questões abertas que investigaram a experiência no que concerne ao atendimento em casos de TAE, bem como aspectos que dificultavam e facilitavam esse atendimento, na percepção dos profissionais de segurança.

\subsubsection{Procedimentos}

\subsubsection{Coleta de dados}

Após a aprovação pelo Comitê de Ética da PUC-Goiás (número da aprovação CAAE: 54798416.9.0000.0037), foi iniciado o processo de coleta de dados. Primeiramente, foi realizada a seleção dos participantes de forma aleatória e estratificada, porém, levando em conta os critérios de inclusão e exclusão. Os locais da coleta de dados foram os batalhões da Polícia Militar e do Corpo de Bombeiros Militar. Seguiu-se a forma 
de coleta de dados estabelecida pelas instituições e atendendo à disponibilidade de salas do local (Academias CBM e PM) e o plantão dos militares.

A aplicação foi organizada de forma coletiva, em salas de aula, com preenchimento individual, na modalidade autoaplicada. Os participantes foram esclarecidos sobre a proposta da pesquisa, tendo sido realizada a leitura do Termo de Consentimento Livre e Esclarecido (TCLE), reforçado seu anonimato e sigilo, assim como o fato de que a participação seria voluntária. A todos os participantes solicitou-se a assinatura do TCLE, caso aceitassem responder a pesquisa.

\subsubsection{Análise de dados}

Para analisar os dados, foi realizado tratamento estatístico por meio do programa Statistical Package for the Social Sciences (SPSS 20.0) para Windows. Análises estatísticas descritivas e inferenciais foram realizadas, tendo em vista os objetivos do estudo.

Na parte quantitativa, foram realizados cálculos para a análise dos componentes principais da EMCS, de Valores Organizacionais (EVO) e do Questionário Psicossocial de Valores (QPV-24) na amostra de militares do presente estudo. Foi realizada uma análise fatorial a partir do método de análise dos componentes principais (ACP) que procura sintetizar a informação presente num conjunto de variáveis correlacionadas por meio de um modelo matemático, bem definido, e que conduz, geralmente, a uma única solução. Foi aplicado o método de rotação ortogonal varimax, técnica que tenta maximizar a dispersão das cargas nos fatores, buscando agregar um menor número de variáveis sobre cada um. Ademais, para avaliação da fidedignidade, foi realizado o cálculo da confiabilidade da solução fatorial, alpha de Cronbach, que aponta se a escala reflete o construto que está medindo (Cronbach, 1996; Field, 2009; Hair et al., 2009). Técnicas estatísticas descritivas 
também foram utilizadas, como frequências, porcentagens, médias e desvios-padrão. No que tange à estatística inferencial, foram calculados Teste T de Student, Anova, correlação de Pearson e regressão linear múltipla pelos métodos stepwise e enter (Pasquali, 2003).

Os dados qualitativos foram elencados em categorias de análise e subcategorias, que foram listadas e, então, julgadas pelo procedimento de Análise Semântica e de Juízes (Pasquali, 2003). Posteriormente, foi computado o número de vezes em que as categorias/subcategorias foram citadas, mas não por número de respondentes, e sim caso um participante tenha mencionado três aspectos, todos foram computados.

\subsection{Resultados}

Os resultados são apresentados em cinco seções. Na primeira, estão descritos os dados referentes ao perfil sociodemográfico dos participantes. Na segunda, as análises das características psicométricas das escalas utilizadas na amostra de militares. Na terceira, são apresentados os resultados que respondem aos objetivos específicos deste estudo. $\mathrm{Na}$ quarta, os resultados que respondem aos objetivos gerais. E na quinta e última seção são apresentadas as descrições das análises dos resultados relativos às questões abertas, em que se buscou identificar a opinião em relação ao atendimento do suicídio e os fatores que facilitam ou dificultam esse atendimento.

\subsubsection{Caracterização dos participantes}

Participaram, inicialmente, 534 militares, sendo 163 bombeiros e 371 policiais

militares. Após a conferência dos questionários, 70 sujeitos (9 dos CBM e 61 dos PM) foram excluídos, porque deixaram itens em branco ou responderam igualmente os itens, resultando, assim, em 464 militares, sendo 24,3\% do CBM ( $n=97), 60,5 \%$ da PM ( $n=242)$ 
da cidade de Goiânia, Goiás. Foram contabilizados, ainda, aqueles militares que estavam realizando curso na cidade e responderam o instrumento, sendo $13,8 \%(n=55)$, de CBM e 1,5\% $(n=6)$ de PM de outros estados. Deixaram de responder a identificação da instituição $13,8 \%$ participantes $(n=64)$.

Os participantes eram, em sua maioria, $87 \%(\mathrm{n}=340)$, do sexo masculino, $13 \%$ $(\mathrm{n}=51)$ do feminino e $15,7 \%(\mathrm{n}=73)$ deixaram essa resposta em branco. A média de idade dos militares foi igual a 38 anos $(\mathrm{DP}=7,56$, mediana=39; mínimo=21 anos, máximo=57 anos). O cálculo da média de idade dos $\mathrm{PMs}$ resultou em 46 anos $(\mathrm{DP}=7,07)$ e 36 anos para o $\mathrm{CBM}(\mathrm{DP}=4,73)$. Os militares informaram, em sua maioria, 66,4\% $(\mathrm{n}=265)$, serem casados, 15,5\% $(\mathrm{n}=62)$ solteiros, 10,3\% $(\mathrm{n}=41)$ divorciados, 7,8\% $(\mathrm{n}=31)$ em outras situações conjugais e $14 \%(\mathrm{n}=65)$ não responderam a questão. A maior parte, $51,7 \%$ $(n=200)$ referiu ser da religião católica, 31\% $(n=120)$ informaram serem protestantes/evangélicos, $14,4 \%(n=67)$ de outras religiões e 16,6\% $(n=77)$ não especificaram sua vinculação religiosa. A média da autoavaliação sobre a importância da religião na vida dos participantes foi igual a oito, em escala de zero a $10(\mathrm{DP}=2,45$, mediana=9, mínimo=0 e máximo=10).

Em relação ao nível de escolaridade, 48,4\% (n=193) possuíam ensino superior completo, 23,3\% (n=93) eram pós-graduados, 7,5\% $(\mathrm{n}=30)$ tinham curso superior incompleto e $20,8 \%(n=83)$ relataram ensino médio, enquanto $14 \%(n=65)$ deixaram essa questão em branco. No que se refere à classificação dos cargos exercidos na instituição, $1,5 \%(n=6)$ eram soldados, $13,1 \%(52)$ cabos, 33\% ( $n=131)$ sargentos, $14,4 \% \quad(n=57)$ tenentes, $0,8 \%(n=3)$ capitães, 35,5\% $(n=141)$ cadetes ou subtenentes, $1,8 \%(n=7)$ outros cargos e 14,4\% (n=67) não declararam.

Ademais, foi perguntado se o militar já havia atendido ocorrência de suicídio: 39,9\% ( $\mathrm{n}=138)$ declararam que sim, a maioria, 60,1\% ( $\mathrm{n}=158)$, relatou que não havia 
passado por essa experiência e 14,7\% $(n=68)$ dos participantes não responderam a pergunta. Em caso positivo, foi indagado quantas vezes ele havia realizado a atividade, sendo a média de atendimentos de 6 vezes $(\mathrm{DP}=7,43$, mediana=3, mínimo=1 e máximo=50).

\subsubsection{Características psicométricas das escalas utilizadas para este estudo}

Todas as escalas utilizadas foram submetidas a dois tipos de análises estatísticas: primeiramente, à análise dos componentes principais (ACP) e de consistência interna dos itens. A ACP foi aplicada a fim de investigar a validade de construto desta escala. Essa técnica estatística objetiva descobrir a estrutura de um conjunto de variáveis, nesse caso, os itens de cada escala, com base nas correlações existentes entre eles. Em seguida, foram extraídos os respectivos alphas de Cronbach. Pasquali (2003) afirma que o alpha de Cronbach se refere à avaliação da consistência interna entre os itens, ou seja, esse coeficiente geral reflete o grau de covariância dos itens entre si, indicando a consistência interna do instrumento.

O resultado da análise fatorial dos itens da EMCS, para este estudo, apresentou um único fator com autovalor igual a 3,365, com variância igual a 10,5\% (KMO=0,69; Teste de Esfericidade de Bartllet=1371,668; $\mathrm{p}<0,001)$ e $\alpha=0,70$. Os 32 itens foram mantidos, com cargas fatoriais acima de 0,30 . Portanto, essa escala é válida para mensurar os mitos e as crenças sobre o suicídio em profissionais da área da segurança pública de Goiás.

Com a finalidade de realizar as análises comparativas com a Escala de Mitos e Crenças sobre o Suicídio, foi feita a normatização estatística das respostas do grupo pesquisado (profissionais da área de segurança). Para isso, foram levantados os itens que deveriam ter respostas verdadeiras e falsas, possibilitando identificar o número de acertos e erros (Figura 4), conforme critérios de correção estabelecidos teoricamente e que 
permitiram, então, calcular o percentil do escore bruto das respostas. Essa normatização possibilita utilizar a análise estatística paramétrica a fim de comparar as médias entre os grupos.

\begin{tabular}{|c|}
\hline Itens com acerto nas respostas verdadeiras \\
\hline $3,5,9,11,13,15,18,25,28,30$ \\
\hline Itens com acerto nas respostas falsas \\
\hline $1,2,4,6,7,8,10,12,14,16,17,19,20,21,22,23,24,26,27,28,29,31,32$ \\
\hline
\end{tabular}

Figura 4. Critérios de Correção dos itens da Escala de Mitos e Crenças sobre o Suicídio para Profissionais de Segurança, de acordo com o Gabarito de Acertos e Erros nas Respostas.

Fonte: Dados da pesquisa.

De acordo com os critérios de correção da Escala Mitos e Crenças sobre o Suicídio para profissionais de segurança, observa-se que 10 itens deveriam ser marcados como verdadeiro e 22 itens como falso (Figura 4). Nesse sentido, foi realizado o agrupamento dos itens verdadeiros e dos itens falsos, possibilitando avaliar o número de acertos e erros em cada conjunto de itens.

No sentido de tornar os itens da escala avaliados por número de erros e acertos, foi necessário levantar quais deles são considerados verdadeiros e falsos e, assim, transformar os dados nominais em escalares para possibilitar os cálculos paramétricos. Dessa maneira, foram criadas novas categorias para as respostas dos participantes deste estudo, que seguiram a seguinte lógica: para os itens que tinham de ter como respostas 'verdadeiro', onde foi marcado o ' $\mathrm{V}$ ' foi considerado o número 1 e marcado ' $\mathrm{F}$ ' o número 0 ; para os itens que tinham de ter como respostas 'falso', onde foi marcado o ' $\mathrm{F}$ ' foi considerado o número 1 e marcado ' $\mathrm{V}$ ' o número 0 . Logo, a soma total dos itens verdadeiros e falsos corresponde ao escore de acertos das respostas obtidos pelos participantes.

Os itens da escala sobre valores pessoais (QVP-24) também foram submetidos à análise de componentes principais (ACP), por ser aplicada em um grupo específico de profissionais. Os resultados confirmaram a existência de quatro fatores com autovalores 
superiores a 1 (de 1,182 a 7,067). Observou-se que, pela análise fatorial, para esse grupo de policiais militares a fatorabilidade da escala agrupou os itens, juntando os fatores hedonismo e materialismo, bem como agrupou os itens de bem-estar individual e profissional. Além disso, o item referente ao amor foi inserido no valor bem-estar social. Esses agrupamentos diferem da validação original e podem ter sofrido influência da cultura militar, que faz parte da identificação dos militares. No caso do hedonismo e do materialismo, isso pode ter ocorrido pelo fato de esses valores serem de ordem individualista, em que muitas vezes não são reforçados em uma corporação. Em relação ao bem-estar profissional e individual, isso pode ter ocorrido devido à identificação que o militar tem com sua profissão. Além do mais, para que haja bem-estar individual é necessário que exista o profissional, já que eles trabalham constantemente com situações de risco. Em relação ao amor estar inserido na dimensão do bem-estar social, talvez tenha a ver com a questão de ele ser entendido como um valor universal, pois os militares cuidam do bem-estar social, que é uma forma de amor.

De acordo com as análises, embora nenhum item tenha sido eliminado, eles se agruparam de forma diferente da validação original. A QVP-24 para este estudo passou a ser composta de quatro fatores: valores hedonismo/materialismo, valores de bem-estar individual e profissional, valores de bem-estar social e valores religiosos. O primeiro fator possuía seis itens e mensurou o hedonismo e o materialismo, explicando 29,45\% da variância $(\alpha=0,86)$; o segundo fator, que avaliou o bem-estar individual e profissional, abarcou sete itens, que explicaram $14,37 \%$ da variabilidade $(\alpha=0,84)$; o terceiro fator consistiu de cinco itens que avaliam o bem-estar social e explicou $8,98 \%$ da variabilidade $(\alpha=0,80)$; por fim, o quarto fator são quatro itens que avaliam o fator religião, explicando $4,92 \%$ da variabilidade $(\alpha=0,83)$ (Tabela 4$)$. 
Tabela 4. Distribuição das Cargas Fatoriais dos Itens da Escala de Valores Pessoais, conforme os Quatro Fatores Identificados na Amostra de Militares.

\begin{tabular}{|c|c|c|c|c|c|}
\hline \multirow{2}{*}{ Fatores } & \multirow{2}{*}{ Itens do QVP } & \multicolumn{4}{|c|}{ Carga Fatorial } \\
\hline & & 1 & 2 & 3 & 4 \\
\hline Hedonista/ materialista & $\begin{array}{l}\text { 9.QVP_riqueza } \\
\text { 10.QVP_sensualidade } \\
\text { 11.QVP_status } \\
\text { 12.QVP_uma vida excitante } \\
\text { 14.QVP_autoridade } \\
\text { 18.QVP_lucro } \\
\text { 19.QVP_prazer } \\
\text { 23.QVP_sexualidade }\end{array}$ & $\begin{array}{l}0,719 \\
0,805 \\
0,810 \\
0,822 \\
0,623 \\
0,777 \\
0,464 \\
0,624 \\
\end{array}$ & & & \\
\hline $\begin{array}{l}\text { Bem estar individual/ bem } \\
\text { estar profissional }\end{array}$ & $\begin{array}{l}\text { 1.QVP_alegria } \\
\text { 2.QVP_autorrealização } \\
\text { 3.QVP_competência } \\
\text { 4.QVP_dedicação ao trabalho } \\
\text { 15.QVP_conforto } \\
\text { 20.QVP_realização profissional } \\
\text { 21.QVP_responsabilidade }\end{array}$ & & $\begin{array}{l}0,515 \\
0,645 \\
0,761 \\
0,742 \\
0,484 \\
0,693 \\
0,652 \\
\end{array}$ & & \\
\hline Bem estar social & $\begin{array}{l}\text { 5.QVP_igualdade } \\
\text { 6.QVP_liberdade } \\
\text { 13.QVP_amor } \\
\text { 16.QVP_fraternidade } \\
\text { 17.QVP_justiça social }\end{array}$ & & & $\begin{array}{l}0,651 \\
0,689 \\
0,620 \\
0,738 \\
0,760\end{array}$ & \\
\hline Religioso & $\begin{array}{l}\text { 7.QVP_obediencia às leis de Deus } \\
\text { 8.QVP_religiosidade } \\
\text { 22.QVP_salvação da alma } \\
\text { 24.QVP_temor a Deus }\end{array}$ & & & & $\begin{array}{l}0,850 \\
0,672 \\
0,779 \\
0,865\end{array}$ \\
\hline
\end{tabular}

Fonte: Dados da pesquisa.

A EVO também foi submetida à análise para avaliar os pressupostos que favorecem a utilização da análise fatorial para este estudo. A partir dessa análise foi possível constatar que a matriz apresenta-se fatorável para extrair os fatores dos itens $(\mathrm{KMO}=0,959$; Teste de Esfericidade de Bartllet $=11120,410 ; \mathrm{p}<0,001)$.

Em seguida, por meio da AFE, os dados foram rodados sem fixação de fatores e sem rotação. Os resultados apresentaram comunalidades de 0,533 a 0,716. Ao analisar o teste Scree de Cattell, que avalia os fatores baseado no critério de autovalores, observou-se que esse instrumento de medidas apresenta 38 fatores com autovalores superiores a 1 (de 1,052 a 15,820), ilustrando uma estrutura multifatorial. Porém, quando se analisa o gráfico do scree plot, observa-se que há uma mudança forte na direção da curva para dois fatores com autovalores acima de $3(3,439$ e 15,820), ilustrando uma estrutura bifatorial. Laros (2012) afirma que a mudança no gráfico se deu no sentido de os pontos ficarem acima da 
reta, representando os fatores triviais. Portanto, deve-se seguir esse critério para extrair o número de fatores de forma correta (Figura 5).

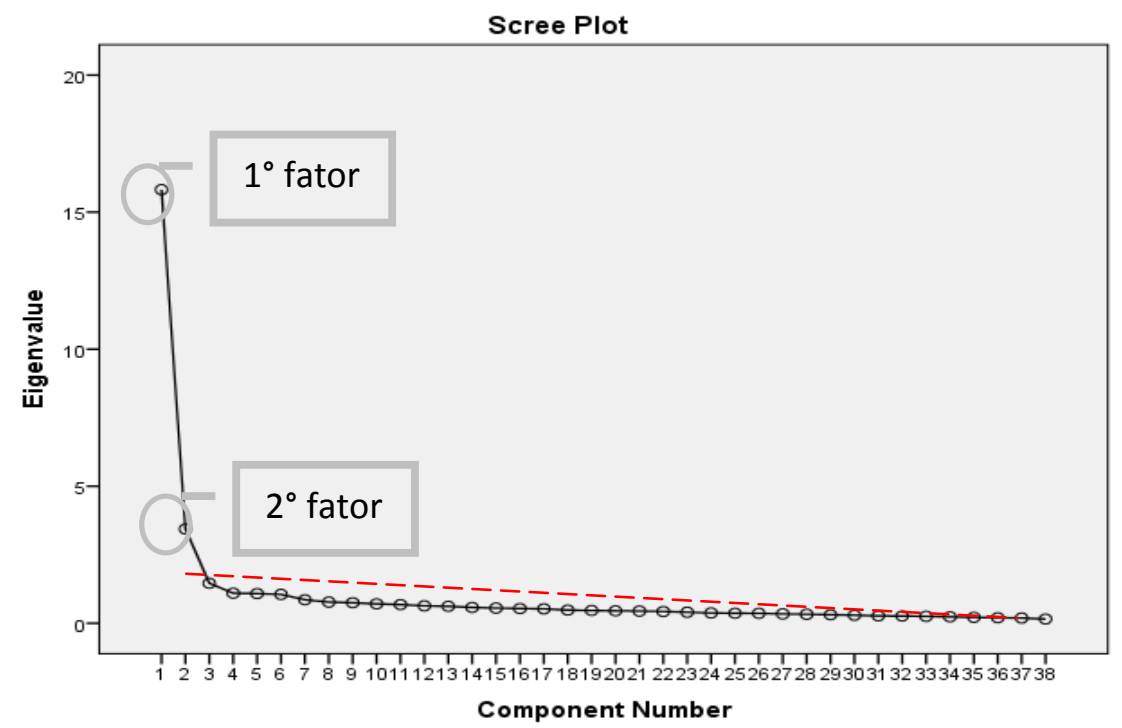

Figura 5. Gráfico Representativo dos Autovalores do Scree Plot para os Dados da EVO, Mostrando o Ponto que Separa os Fatores Triviais dos Não Triviais (Laros, 2012).

Partindo do pressuposto de Laros (2012), realizou-se também a análise dos componentes principais (APC) para a EVO para dois fatores. Os resultados dos agrupamentos dos fatores da AFE e da ACP foram similares. De acordo com os dados, pode-se constatar que nenhum item foi descartado, porém, os dois fatores se agruparam com autovalores superiores a $3(3,439$ e 15,820). O primeiro fator consistiu de 29 itens, denominado reconhecimento profissional com variância explicada igual a 41,63\% $(\alpha=0,96)$, e o segundo fator com nove itens, denominado reconhecimento de produtividade com variância explicada de $9,05 \%(\alpha=0,81)$.

Tamayo e Gondim (1996) afirmam que quase todo trabalhador detecta os diferentes valores que sobressaem na organização e que determinam o clima e a cultura organizacional. Os autores ainda ressaltam que os valores organizacionais constituem o núcleo da cultura organizacional. Acrescentam que a estrutura axiomática da instituição “especifica a natureza das crenças e dos princípios que dominam na organização e o seu tipo de motivação característico" (p. 64). Ademais, a percepção dessa estrutura é um 
elemento cognitivo que torna possível ao trabalhador criar uma estrutura mental sobre a organização. Assim, modelos diferentes de estrutura mental permitem percepções diferentes, o que explica a nova configuração fatorial da QVP-24 para os militares. A cultura militar apresenta aspectos cognitivos diferentes da cultura civil, explicando sua nova forma de configuração dos fatores (Tabela 5).

Os resultados da ACP e da consistência interna dos itens da EVO apontaram que essa escala é válida para mensurar os valores organizacionais em duas dimensões na amostra de militares. Portanto, foi possível observar que a primeira dimensão avalia como os profissionais percebem a existência de valores da organização em relação ao reconhecimento profissional; já a segunda dimensão se refere à avaliação do quanto os profissionais da área da segurança pública percebem que sua instituição reconhece a sua produtividade (Tabela 5).

Tabela 5. Distribuição das Cargas Fatoriais dos Itens da Escala de Valores Organizacionais.

\begin{tabular}{lcc}
\hline \multicolumn{1}{c}{ Fatores Itens do EVO } & Carga Fatorial \\
\hline & & $\mathbf{1}$ \\
\hline 1. Abertura (promoção de um clima propício às sugestões e ao diálogo) & 0,698 \\
2. Amizade (clima de relacionamento amistoso entre os militares) & 0,657 \\
3. Benefícios (promoção de programas assistenciais aos militares) & 0,678 \\
4. Coleguismo (clima de compreensão e apoio aos entre os militares) & 0,648 \\
5. Competência (saber executar as tarefas da organização) & 0,613 \\
7. Comprometimento (identificação com a missão da instituição) & 0,532 \\
8. Cooperação (clima de ajuda mútua) & 0,710 \\
9. Criatividade (capacidade de inovar a instituição) & 0,741 \\
10. Dedicação (promoção ao trabalho com afinco) & 0,542 \\
11. Democracia (participação de todos militares envolvidos nos processos & 0,732 \\
decisórios) & 0,589 \\
12. Eficácia (fazer as tarefas de forma a atingir os objetivos esperados) & 0,564 \\
13. Eficiência (executar as tarefas da instituição de forma certa) & 0,656 \\
15. Flexibilidade (administração que se adapta às situações concretas) & 0,785 \\
16. Harmonia (ambiente de relacionamento interpessoal adequado) & 0,574 \\
18. Honestidade (promoção de combate à corrupção na instituição) & 0,754 \\
19. Incentivo à pesquisa (incentivo à pesquisa relacionada com interesses da & \\
organização) & 0,667 \\
20. Integração interorganizacional (intercâmbio com outras instituições) & 0,718 \\
21. Justiça (imparcialidade nas decisões administrativas) & 0,698 \\
22. Modernização de recursos materiais (preocupação em investir na aquisição de \\
equipamentos, programas de informática e outros)
\end{tabular}




\begin{tabular}{|c|c|c|c|}
\hline \multirow{2}{*}{ Fatores } & \multirow{2}{*}{ Itens do EVO } & \multicolumn{2}{|c|}{ Carga Fatorial } \\
\hline & & 1 & 2 \\
\hline & 25. Planejamento (elaboração de planos para evitar improvisação na organização) & 0,685 & \\
\hline & 26. Plano de Carreira (preocupação com a carreira funcional dos militares) & 0,701 & \\
\hline & 27. Polidez (clima de cortesia e educação no relacionamento cotidiano) & 0,725 & \\
\hline & 30. Probidade (administrar de maneira adequada o dinheiro público) & 0,477 & \\
\hline & 32. Qualidade (compromisso com o aprimoramento dos produtos e serviços) & 0,616 & \\
\hline & $\begin{array}{l}\text { 33. Qualificação de recursos humanos (promover a capacitação e treinamento do } \\
\text { efetivo) }\end{array}$ & 0,718 & \\
\hline & 34. Reconhecimento (reconhecimento do mérito na realização do trabalho) & 0,765 & \\
\hline & 35. Respeito (consideração às pessoas e opiniões) & 0,805 & \\
\hline & 36. Sociabilidade (estímulo às atividades sociais fora do ambiente de trabalho) & 0,772 & \\
\hline & 6. Competitividade (conquistar a população em relação à outras instituições) & & 0,443 \\
\hline & 14. Fiscalização (controle do serviço executado) & & 0,694 \\
\hline & 17. Hierarquia (respeito aos níveis de autoridade) & & 0,661 \\
\hline & 23. Obediência (tradição e respeito às ordens) & & 0,697 \\
\hline 2 & 28. Pontualidade (preocupação com o cumprimento de horários e compromissos) & & 0,674 \\
\hline 2 & $\begin{array}{l}\text { 29. Postura profissional (promover a execução das funções ocupacionais de } \\
\text { acordo com as normas da organização) }\end{array}$ & & 0,576 \\
\hline & 31. Produtividade (atenção voltada para a produção e a prestação de serviços) & & 0,505 \\
\hline & 37. Supervisão (acompanhamento e avaliação contínuos da tarefa) & & 0,615 \\
\hline & 38. Tradição (preservar usos e costumes da organização) & & 0,617 \\
\hline
\end{tabular}

Nota. Valores de Reconhecimento Profissional (Fator 1); Valores de Reconhecimento de Produtividade (Fator 2).

Fonte: Dados da pesquisa.

Em conjunto, todos os parâmetros psicométricos (Pasquali, 2003) dos instrumentos usados neste trabalho estão nos limites de significância estatística utilizados em psicologia, podendo, assim, ser empregados em análises posteriores.

\subsubsection{Relação entre as variáveis pessoais e mitos e crenças sobre o suicídio}

Quando analisados os dados referentes à EMCS e as variáveis sociodemográficas em relação à amostra total, foi possível observar que os 464 profissionais de segurança pública (PM e CBM) apresentaram uma variação de número de acertos entre 8 e 31, com média 24,85 e mediana 25 e desvio padrão de 3,298 (Tabela 6).

Tabela 6. Análise Descritiva do Número de Acertos (escore médio) Relativo à EMCS

\begin{tabular}{cccccc}
\hline $\mathbf{N}$ & $\mathbf{M}$ & Mediana & DP & Mínimo & Máximo \\
\hline 464 & 24,85 & 25,00 & 3,30 & 8 & 31 \\
\hline
\end{tabular}

Fonte: Dados da pesquisa. 
Em seguida, foram realizadas análises comparativas para avaliar a ocorrência de diferenças em relação aos escores na EMCS de acordo com sexo, idade, corporação, formação e cargo.

Ao avaliar se havia diferença estatística (Teste T) em relação ao escore da EMCS e as variáveis pessoais, observou-se a ocorrência de diferença estatisticamente significativa em relação às variáveis sexo, idade, formação e cargo. Os resultados apontaram que mulheres e profissionais mais novos, com formação de nível superior e no cargo de oficiais, acertaram mais as questões do que os homens, profissionais mais velhos, com ensino médio e no cargo de praça. Ou seja, os profissionais que trabalhavam na área da segurança pública do sexo feminino, com menos de 38 anos de idade, com ensino superior e no cargo de oficiais possuíam mais informações relativas ao suicídio compatíveis com a literatura científica sobre o tema (Tabela 7). A corporação não diferenciou os dois grupos pesquisados.

Tabela 7. Médias, Desvios-Padrão e Valores do Teste T a partir dos Escores na EMCS em Relação a Sexo, Idade, Corporação, Formação e Cargo.

\begin{tabular}{|c|c|c|c|c|}
\hline \multirow{2}{*}{$\frac{\text { EMCS }}{\text { Sexo }}$} & \multicolumn{2}{|c|}{ Variáveis } & \multicolumn{2}{|c|}{ Teste $\mathbf{T}$} \\
\hline & Feminino $(\mathrm{n}=51)$ & Masculino $(\mathrm{n}=340)$ & $T$ & $P$ \\
\hline$M$ & 26,49 & 24,66 & & \\
\hline$D P$ & 2,101 & 3,393 & 5,26 & $0,000^{* * *}$ \\
\hline Idade & $\leq \mathbf{3 8}$ anos $(\mathrm{n}=202)$ & $\geq 39 \operatorname{anos}(n=192)$ & $T$ & $P$ \\
\hline $\begin{array}{l}M \\
D P\end{array}$ & $\begin{array}{l}25,28 \\
3,460\end{array}$ & $\begin{array}{l}24,45 \\
3,120\end{array}$ & 2,51 & $0,012^{*}$ \\
\hline Corporação & CBM $(n=152)$ & PM $(n=248)$ & $T$ & $\boldsymbol{P}$ \\
\hline $\begin{array}{c}M \\
D P \\
\end{array}$ & $\begin{array}{l}24,89 \\
3,579 \\
\end{array}$ & $\begin{array}{l}24,85 \\
3,195 \\
\end{array}$ & 0,113 & 0,723 \\
\hline Formação & $\begin{array}{c}\text { Ensino médio e } \\
\text { superior incompleto } \\
(\mathrm{n}=113)\end{array}$ & $\begin{array}{c}\text { Ensino superior } \\
\text { ou mais }(n=286)\end{array}$ & $T$ & $\boldsymbol{P}$ \\
\hline $\begin{array}{c}M \\
D P\end{array}$ & $\begin{array}{c}24,06 \\
3,65 \\
\end{array}$ & $\begin{array}{r}25,17 \\
3,16\end{array}$ & $-2,83$ & $0,005 * *$ \\
\hline Cargo & Praça $(n=189)$ & Oficiais $(n=201)$ & $T$ & $\boldsymbol{P}$ \\
\hline $\begin{array}{c}M \\
D P\end{array}$ & $\begin{array}{c}24,49 \\
3,59\end{array}$ & $\begin{array}{c}25,23 \\
3,03 \\
\end{array}$ & $-2,190$ & $0,028^{*}$ \\
\hline
\end{tabular}

Nota: ** $\mathrm{p} \leq 0,001 ; \quad * * \mathrm{p} \leq 0,01 \quad * \mathrm{p} \leq 0,05$.

Fonte: Dados da pesquisa. 
Ao avaliar a presença de diferenças nos escores médios (Anova) quanto ao número de acertos na ECMS e a religião $\left(\mathrm{F}_{(2,386)}=0,461 ; \mathrm{p}=0,631\right)$ e a situação conjugal $\left(\mathrm{F}_{(3,398)}=2,059 ; \mathrm{p}=0,105\right)$, foi possível observar que não houve diferença estatística significativa. Portanto, o número de acertos na EMCS dos profissionais da segurança pública não apresentou diferença relevante em relação à sua religião e à situação conjugal (Tabela 8).

Tabela 8. Médias, Desvios-Padrão e Valores da Anova a partir dos Escores da EMCS em Relação à Religião e à Situação Conjugal.

\begin{tabular}{|c|c|c|c|c|c|c|}
\hline & \multicolumn{4}{|c|}{ Religião } & \multicolumn{2}{|c|}{ Anova } \\
\hline & $\begin{array}{l}\text { Católica } \\
(\mathrm{n}=200)\end{array}$ & $\begin{array}{c}\text { Protestante } \\
(\mathrm{n}=120)\end{array}$ & $\begin{array}{c}\text { Outra } \\
(\mathrm{n}=67)\end{array}$ & & $F$ & $P$ \\
\hline$M$ & 24,63 & 24,94 & 25,00 & & & \\
\hline \multirow[t]{3}{*}{$D P$} & 3,458 & 3,00 & 3,573 & & 4,461 & 0,631 \\
\hline & \multicolumn{4}{|c|}{ Situação Conjugal } & \multicolumn{2}{|c|}{ Anova } \\
\hline & $\begin{array}{c}\text { Casado/união } \\
\text { consensual } \\
(\mathrm{n}=265)\end{array}$ & $\begin{array}{l}\text { Solteiro } \\
(\mathrm{n}=62)\end{array}$ & $\begin{array}{c}\text { Divorciado } \\
(\mathrm{n}=41)\end{array}$ & $\begin{array}{l}\text { Outros } \\
(\mathrm{n}=31)\end{array}$ & $F$ & $P$ \\
\hline$M$ & 24,69 & 25,72 & 24,27 & 25,00 & 2050 & 0105 \\
\hline$D P$ & 3,432 & 3,412 & 3,049 & 2,477 & 2,005 & \\
\hline
\end{tabular}

Nota: * As médias compartilham diferença significativa, $\mathrm{p}<0,01$, no teste Scheffé.

Fonte: Dados da pesquisa.

De acordo com os dados das análises Anova (Tabela 8) para religião e situação conjugal, comparados ao número de acertos na escala EMCS, pode-se constatar que pertencer a distintas religiões e situação conjugal não diferenciou os grupos quanto a mitos e crenças acerca do suicídio.

\subsubsection{Mitos e crenças de profissionais militares (PM e CBM) sobre o suicídio}

Para realizar a análise geral sobre o nível de acertos nas respostas sobre mitos e crenças que os profissionais que atuam na área da segurança pública possuem, foi necessário observar as respostas apresentadas por eles no percentil médio, ou seja, 53\% das respostas estavam certas, enquanto $47 \%$ estavam erradas. Portanto, pode-se concluir 
que os profissionais de atendimento em emergência apresentam escores medianos em relação à formação de mitos e crenças sobre o suicídio.

Analisando os itens respondidos com maior porcentagem de erros, correspondentes aos mitos e às crenças que os profissionais da área da segurança pública tinham sobre o suicídio, pode-se dizer que se destacam: “A depressão é um diagnóstico óbvio, fácil de ser percebido" (82,6\%); "Falar sobre suicídio com pessoas deprimidas pode estimulá-las a uma tentativa" (64,2\%); "É preciso ter sangue frio para trabalhar com um paciente suicida" $(61,2 \%)$; “Quem tem ideação ou outros comportamentos suicidas tem mais risco de morrer por qualquer outra causa (por problemas de saúde, homicídio ou acidentes" (58,7\%); "Ele tomou só aspirina. Na verdade, não queria morrer" (47,8\%); "Suicídio é um ato de covardia" (37,7\%); “O impulso suicida é agudo e passageiro" (37,5\%); e "Quem realmente quer se matar, não avisa, se mata da primeira vez” (35,3\%) (Tabela 9).

Por outro lado, observa-se (Tabela 9) que os maiores acertos de respostas foram nas questões "É preciso ter calma e paciência para ajudar uma pessoa que fez uma tentativa" (verdadeiro), "Quem tem raiva do suicida tem razão de lhe dar o troco" (falso), "Se um paciente melhorou rapidamente, ele está fora de risco. Posso ficar tranquilo" (falso), revelando mais conhecimento dos participantes nesses temas.

Tabela 9. Porcentagem de Acertos e Erros na ECMS.

\begin{tabular}{lcc}
\multicolumn{1}{c}{ Itens da ECMS } & Erros e acertos & $\%$ \\
\hline 1. O impulso suicida é agudo e passageiro. & Errou & 37,5 \\
2. A tentativa de suicídio representa uma vontade de aparecer, de chamar a & acertou & 62,5 \\
atenção. & errou & 25,2 \\
3. Via de regra, é mais seguro pensar que quem tenta suicídio uma vez, tentará & acertou & 74,8 \\
outras. & errou & 9,8 \\
4. A tentativa de suicídio é uma manipulação. & acertou & 90,2 \\
& errou & 12,4 \\
5. É preciso ter calma e paciência para ajudar uma pessoa que fez uma tentativa. & acertou & 87,6 \\
& errou & 2,2 \\
& acertou & 97,8 \\
6. Uma vez suicida, a pessoa será sempre suicida. & errou & 24,5 \\
& acertou & 75,5 \\
7. A tendência suicida é hereditária, passa de geração a geração. & errou & 14,6 \\
& acertou & 85,4 \\
\hline
\end{tabular}


(continuação Tabela 9)

8. As pessoas que ameaçam, não se matam.

9. O desejo de morte ou comportamento de risco de suicídio geralmente é resultado de um longo e silencioso processo de sofrimento, que poderia ter sido relatado ou observado precocemente.

10. Quem realmente quer se matar, não avisa, se mata da primeira vez.

11. A tentativa de suicídio representa um pedido desesperado de ajuda.

12. Ele tomou só aspirina. Na verdade, não queria morrer.

13. Existem pessoas em risco que não podem ser deixadas sozinhas.

14. Suicídio é um ato de coragem.

15. Quem tem ideação ou outros comportamentos suicidas tem mais risco de morrer por qualquer outra causa (por problemas de saúde, homicídio ou acidentes)

16. Quem tem raiva do suicida tem razão de lhe dar o troco

17. Sugerir formas de se matar para um suicida não representa um perigo real.

18. O desespero é um sentimento comum em quem faz uma tentativa de suicídio.

19. Só vai atrapalhar dar muita atenção a quem faz uma tentativa de suicídio.

20. Falar sobre suicídio com pessoas deprimidas pode estimulá-las a uma tentativa.

21. Se ele está falando sobre suas ideias suicidas, isso quer dizer que ele está fora de risco.

22. Quem faz uma tentativa de suicídio para chamar atenção não merece crédito, só vai reforçar o que ele fez.

23. Se um paciente melhorou rapidamente, ele está fora de risco. Posso ficar tranquilo.

24. Quando a gente fala de suicídio, só estamos dando mais força para o comportamento.

25. Uma pessoa em risco, para confiar, precisa se sentir ouvida e respeitada.

26. Se eu der ouvidos a um suicida, ele pode se matar.

27. Só "loucos” cometem suicídio.

28. A depressão é um diagnóstico óbvio, fácil de ser percebido.

29. Quem não tem transtorno mental, não se mata.

30. Conflitos, perdas e separações são os eventos que mais frequentemente antecedem uma tentativa de suicídio.

31. Suicídio é um ato de covardia.

32. É preciso ter sangue frio para trabalhar com um paciente suicida.

\begin{tabular}{|c|c|}
\hline Erros e acertos & $\%$ \\
\hline errou & 14,3 \\
\hline acertou & 85,7 \\
\hline errou & 8,5 \\
\hline acertou & 91,5 \\
\hline errou & 35,3 \\
\hline acertou & 64,7 \\
\hline errou & 16,0 \\
\hline acertou & 84,0 \\
\hline errou & 47,8 \\
\hline acertou & 52,2 \\
\hline errou & 4,8 \\
\hline acertou & 95,2 \\
\hline errou & 18,0 \\
\hline acertou & 82,0 \\
\hline errou & 58,7 \\
\hline acertou & 41,3 \\
\hline errou & 3,0 \\
\hline acertou & 97,0 \\
\hline errou & 11,2 \\
\hline acertou & 88,8 \\
\hline errou & 13,6 \\
\hline acertou & 86,4 \\
\hline errou & 11,9 \\
\hline acertou & 88,1 \\
\hline errou & 64,2 \\
\hline acertou & 35,8 \\
\hline errou & 4,3 \\
\hline acertou & 95,7 \\
\hline errou & 11,4 \\
\hline acertou & 88,6 \\
\hline errou & 3,3 \\
\hline acertou & 96,7 \\
\hline errou & 24,1 \\
\hline acertou & 75,9 \\
\hline errou & 3,5 \\
\hline acertou & 96,5 \\
\hline errou & 8,7 \\
\hline acertou & 91,3 \\
\hline errou & 3,3 \\
\hline acertou & 96,7 \\
\hline errou & 82,6 \\
\hline acertou & 17,4 \\
\hline errou & 8,7 \\
\hline acertou & 91,3 \\
\hline errou & 7,8 \\
\hline acertou & 92,2 \\
\hline errou & 37,7 \\
\hline acertou & 62,3 \\
\hline errou & 61,2 \\
\hline acertou & 38,8 \\
\hline
\end{tabular}


5.2.4.1 Valores pessoais como preditores de mitos e crenças sobre o suicídio

Para compreender melhor os resultados dos valores pessoais, inicia-se a análise pelos dados descritivos. Na escala QVP-24, os itens mais bem avaliados foram amor $(9,61$, $\mathrm{DP}=1,11), \quad$ alegria $\quad(9,38, \quad \mathrm{DP}=1,19), \quad$ fraternidade $\quad(9,22, \quad \mathrm{DP}=1,32) \quad \mathrm{e}$ responsabilidadeempatados $(9,22, \mathrm{DP}=1,34)$. Os valores pessoais com avaliação mais baixa foram status $(5,14, \mathrm{DP}=2,61)$, uma vida excitante $(5,46, \mathrm{DP}=2,65)$ e sensualidade $(5,88), \mathrm{DP}=2,46, \mathrm{n}=464)$.

Em relação à composição dos fatores, nota-se, na Tabela 10, que bem-estar individual e profissional alcançaram a maior média $(61,99)$. Em segundo lugar, estão o hedonismo e materialismo $(51,03)$. Em terceiro, o fator bem-estar social $(45,97)$ e, por fim, o religioso $(34,78)$.

Tabela 10. Análise Descritiva das Variáveis QVP-24 (N=464)

\begin{tabular}{lccccc}
\multicolumn{1}{c}{ Fatores } & M & Mediana & DP & Mínimo & Máximo \\
\hline Hedonismo/Materialismo & 51,03 & 53 & 13,76 & 10 & 80 \\
Bem-estar individual e & 61,99 & 63 & 7,19 & 10 & 70 \\
profissional & 45,97 & 48 & 5,04 & 13 & 50 \\
Bem-estar social & 34,78 & 37 & 7,33 & 0 & 40 \\
Religioso & & & &
\end{tabular}

Fonte: Dados da pesquisa.

Em seguida, foi realizada a análise de correlação de Pearson entre as variáveis valores pessoais e número de acertos em relação aos mitos e às crenças sobre o suicídio. De acordo com os dados apresentados na Tabela 11, foi possível constatar que os valores hedonismo/materialismo e bem-estar social estiveram correlacionados com escores de acertos na escala EMCS. O hedonismo/materialismo correlacionou-se negativamente com o número de acertos na EMCS, o que mostra que esses valores estiveram associados à ocorrência de mitos e crenças sobre o suicídio. Já o bem-estar social correlacionou-se positivamente com os escores da EMCS, o que implica dizer que esteve associado a escores mais altos nessa Escala. 
Tabela 11. Correlação entre Escore da EMCS e Valores Pessoais.

\begin{tabular}{|c|c|c|c|c|c|c|}
\hline Variáveis & & 1 & 2 & 3 & 4 & 5 \\
\hline \multirow{2}{*}{ 1. Escore na EMCS } & $\mathrm{r}$ & 1 & & & & \\
\hline & $\mathrm{p}$ & & & & & \\
\hline \multirow{2}{*}{ 2. QVP Hedonismo/ materialismo } & $\mathrm{r}$ & $-0,129^{* *}$ & 1 & & & \\
\hline & $\mathrm{p}$ & 0,005 & & & & \\
\hline \multirow{2}{*}{ 3. QVP bem-estar individual /profissional } & $\mathrm{r}$ & $-0,010$ & $0,407^{* *}$ & 1 & & \\
\hline & $\mathrm{p}$ & 0,825 & 0,000 & & & \\
\hline \multirow{2}{*}{ 4. QVP bem-estar social } & $\mathrm{r}$ & $0,095^{*}$ & $0,167^{* *}$ & $0,612^{* *}$ & 1 & \\
\hline & $\mathrm{p}$ & 0,040 & 0,000 & 0,000 & & \\
\hline \multirow{2}{*}{ 5. QVP religioso } & $\mathrm{r}$ & $-0,039$ & $0,239^{* *}$ & $0,357^{* *}$ & $0,299^{* *}$ & 1 \\
\hline & $\mathrm{p}$ & 0,406 & 0,000 & 0,000 & 0,000 & \\
\hline
\end{tabular}

Nota: $* * \mathrm{p} \leq 0.001 ; * \mathrm{p} \leq 0,05$

Fonte: Dados da pesquisa.

Por fim, investigou-se se os valores pessoais são preditores de mitos e crenças sobre o suicídio. Para isso, realizou-se uma regressão linear múltipla pelo método stepwise, que possibilita a análise de confirmação ou refutação de hipóteses (Field, 2009).

Diante desses dados (Tabela 12), pode-se dizer que escores mais altos em valores pessoais referentes a hedonismo/materialismo predisseram escores mais baixos indicativos de menos acertos na EMCS $(B=-0,149 ; \mathrm{t}=-3,202 ; \mathrm{p}=0,001)$. Já os trabalhadores que possuem valores pessoais de bem-estar social parecem desenvolver mais habilidades para a compreensão do contexto de suicídio baseado na literatura científica e, portanto, possuem menos mitos e crenças $(B=0,120 ; \mathrm{t}=2,587 ; \mathrm{p}=0,010)$, pois acertaram mais os itens. Ou seja, ter valores pessoais de hedonismo/materialismo associa-se a maior número de mitos e crenças sobre a prática do suicídio, enquanto ter valores de bem-estar social pode levar esses profissionais a adquirirem conhecimento técnico, e consequentemente, uma compreensão mais científica sobre o suicídio.

Já em relação aos valores pessoais, bem-estar individual/profissional $(B=-0,044 ; \mathrm{t}$ $=-0,697 ; \mathrm{p}=0,486)$ e religioso $(B=-0,045 ; \mathrm{t}=-0,911 ; \mathrm{p}=0,363)$, eles não foram preditores para o desenvolvimento de mitos e crenças sobre o suicídio nessa população. 
Tabela 12. Resultados da Regressão Linear Múltipla (Stepwise) Aplicada à Análise dos Fatores Preditivos do Acerto das Respostas Relativas à EMCS em Relação aos Valores Pessoais.

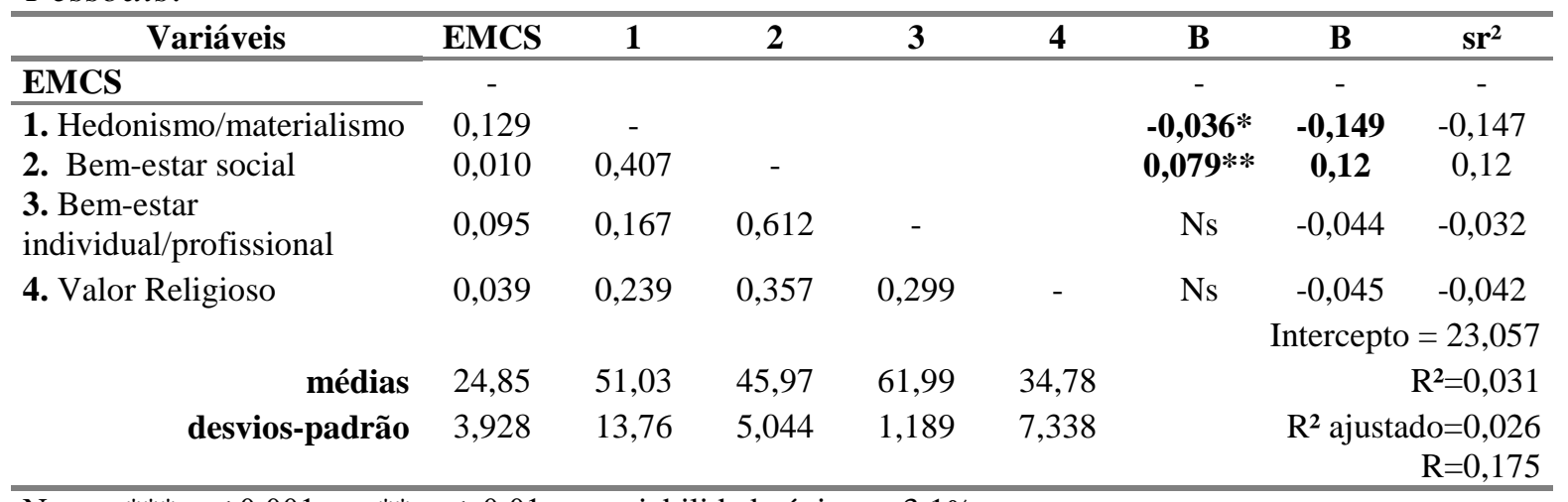

Nota: $* * * p \leq 0,001 \quad * * p \leq 0,01 \quad$ variabilidade única $=3,1 \%$

Fonte: Dados da pesquisa.

Os dados da regressão linear múltipla confirmam a correlação de Pearson apresentada anteriormente, no entanto, observa-se que a variância única explica somente $3,1 \%$ dos efeitos da formação de mitos e crenças pelos fatores dos valores pessoais, hedonismo/materialismo e bem-estar social. Isso implica dizer que, apesar de estatisticamente existir um impacto dos valores pessoais (hedonismo/materialismo e bemestar social) na formulação de mitos e crenças, a variância explicada é muito baixa, pois 96,9\% da influência pode ser explicada por outras variáveis.

5.2.4.2 Valores organizacionais como preditores de mitos e crenças sobre o suicídio

Os resultados descritivos dos valores organizacionais podem ser observados na Tabela 13. A maior média pode ser observada no fator de reconhecimento profissional $(115,96)$, em oposição ao reconhecimento em relação à produção $(44,41)$.

Tabela 13. Análise Descritiva das Variáveis EVO $(N=464)$

\begin{tabular}{lccccc}
\hline \multicolumn{1}{c}{ Fatores } & M & Mediana & DP & Mínimo & Máximo \\
\hline Reconhecimento profissional & 115,96 & 118 & 39,135 & -9 & 196 \\
Reconhecimento produtividade & 44,41 & 46 & 9,504 & 8 & 63 \\
\hline
\end{tabular}

Fonte: Dados da pesquisa. 
A fim de verificar se havia relação entre os valores organizacionais e os acertos na EMCS realizou-se também a análise de correlação de Pearson. Os resultados apresentados na Tabela 14 indicam que não há correlação entre o número de acertos na EMCS com os valores organizacionais, o que implica dizer que os valores organizacionais não influenciaram os profissionais a desenvolverem mitos e crenças relativos às práticas de suicídio.

Tabela 14. Correlação entre o Total de Acertos na Escala EMCS com os Fatores de Valores Organizacionais.

\begin{tabular}{|c|c|c|c|c|}
\hline Variáveis & & 1 & 2 & 3 \\
\hline \multirow{2}{*}{ 1. Total de respostas certas } & $\mathrm{R}$ & 1 & & \\
\hline & $\mathrm{P}$ & & & \\
\hline \multirow{2}{*}{ 2. EVO reconhecimento profissional } & $\mathrm{R}$ & $-0,067$ & \multirow[t]{2}{*}{1} & \\
\hline & $\mathrm{P}$ &, 0148 & & \\
\hline \multirow{2}{*}{ 3. EVO reconhecimento produtividade } & $\mathrm{R}$ & $-0,019$ & $0,471^{* *}$ & \multirow[t]{2}{*}{1} \\
\hline & $\mathrm{P}$ & 0,680 & $\mathbf{0 , 0 0 0}$ & \\
\hline
\end{tabular}

Nota: $\quad * * p \leq 0.001$

Fonte: Dados da pesquisa.

Embora na correlação não tenham sido encontrados valores significativos para a existência de relação entre valores organizacionais e mitos e crenças sobre o suicídio, realizou-se a regressão linear pelo método stepwise para verificar a hipótese deste estudo. No entanto, este método mostrou-se inadequado, talvez por não existir uma teoria suficientemente forte sobre essa relação. À procura, então, de basear-se na teoria sobre os valores organizacionais, a propósito de conhecer as possíveis contribuições destes para formulação de mitos e crenças sobre o que leva uma pessoa a cometer suicídio, realizou-se a regressão linear (enter) entre valores organizacionais (VO) e o número de acertos na EMCS (Tabela 15). 
Tabela 15. Resultados da Regressão Linear Múltipla (Enter) Aplicada à Análise dos Fatores Preditivos do Acerto das Respostas Relativas á EMCS em Relação aos Valores Organizacionais.

\begin{tabular}{|c|c|c|c|c|c|c|}
\hline Variáveis & EMCS & 1 & 2 & B & $\beta$ & $\mathbf{s r}^{2}$ \\
\hline EMCS & - & & & - & - & - \\
\hline \multicolumn{7}{|l|}{ Valores de Reconhecimento } \\
\hline 1. Produtividade & $-0,019$ & - & & 0,006 & 0,016 & 0,014 \\
\hline $\begin{array}{r}\text { médias } \\
\text { desvios-padrão }\end{array}$ & $\begin{array}{l}-0,067 \\
24,85 \\
3,298\end{array}$ & $\begin{array}{l}0,471 \\
44,41 \\
9,504\end{array}$ & $\begin{array}{c}- \\
115,96 \\
39,135\end{array}$ & $-0,006$ & $\begin{array}{l}-0,075 \\
\text { Intercept } \\
\mathrm{R}^{2} \text { ajust }\end{array}$ & $\begin{array}{r}-0,066 \\
=25,335 \\
\mathrm{R}^{2}=0,005 \\
\mathrm{do}=0,000 \\
\mathrm{R}=0,69\end{array}$ \\
\hline
\end{tabular}

Nota: Variabilidade única $=0,5 \%$

Fonte: Dados da pesquisa.

As análises da regressão linear, como esperado, não apresentaram resultados estatisticamente significativos, demonstrando que os valores organizacionais (de reconhecimento de produtividade e profissionalismo) não são preditores para ter conhecimento sobre mitos e crenças sobre o suicídio, conforme Tabela 15.

\subsection{Facilitadores e dificultadores do atendimento em tentativas de autoextermínio (TAE) e suicídio}

As análises foram baseadas nos registros coletados nas questões abertas sobre o atendimento do suicídio: aspectos que facilitam ou dificultam o atendimento. $\mathrm{O}$ respondente era convidado a preencher essa questão caso afirmasse, na questão anterior, sua participação no atendimento de TAE ou em casos de suicídio consumado. Os dados apresentados foram organizados em categorias e subcategorias de análise e estas foram, por sua vez, listadas e, então, julgadas pelos procedimentos Análise Semântica e de Juízes (Pasquali, 2003). O pesquisador inicialmente fez a leitura de todas as respostas, identificando e listando as categorias e possíveis subcategorias. Posteriormente, foi marcado o número das categorias/subcategorias nos questionários. As frequências de respostas foram então computadas pelo número de vezes em que foram referidas, e não por 
número de respondentes. Assim, se um participante escreveu três categorias/subcategorias, todas foram contabilizadas.

Na primeira questão, sobre "o que dificulta o atendimento a pessoas em tentativa de autoextermínio", foram identificadas três categorias: abordagem à vítima, fatores sociais envolvidos no atendimento e aspectos operacionais e emocionais ligados ao profissional. Cada categoria foi dividida em subcategorias, como apresentado na Tabela 16.

Na Polícia Militar, as três subcategorias da abordagem à vítima mais citadas foram "negociar e convencer a vítima do contrário", "manter diálogo e paciência" e "desconhecimento dos motivos que levaram ao ato". No Corpo de Bombeiros Militar, foram "controlar o desequilíbrio psicológico da vítima e a imprevisibilidade do seu ato, "negociar e convencer a vítima do contrário" e "aproximar-se e conquistar sua confiança, mantendo sua calma". Na categoria fatores sociais, a subcategoria mais citada em ambas as corporações foi a dificuldade em lidar com o desespero da família. Na PM, a segunda mais citada envolve a questão da religiosidade, especificado na falta de Deus na vida da vítima; no CBM, a dificuldade em controlar a população curiosa. Em relação aos aspectos operacionais e emocionais, as duas corporações referiram em primeiro lugar sobre a dificuldade imposta pela falta de treinamento e falta de controle emocional da equipe e, em segundo, na PM, a dificuldade em lidar com a cena da tentativa ou do suicídio consumado. No CBM, foi o encaminhamento a hospital especializado (Tabela 16).

Trechos escritos não inteligíveis ou que faziam referência a outros temas não abordados na questão e não foram analisados. 
Tabela 16. Categorias e Subcategorias sobre Dificuldades no Atendimento a Pessoas em Tentativa de Autoextermínio elou Suicídio, Segundo os Participantes.

\begin{tabular}{lccc}
\hline Categorias/subcategorias & Exemplos de relatos & F & F \\
& & PM & CBM \\
\hline
\end{tabular}

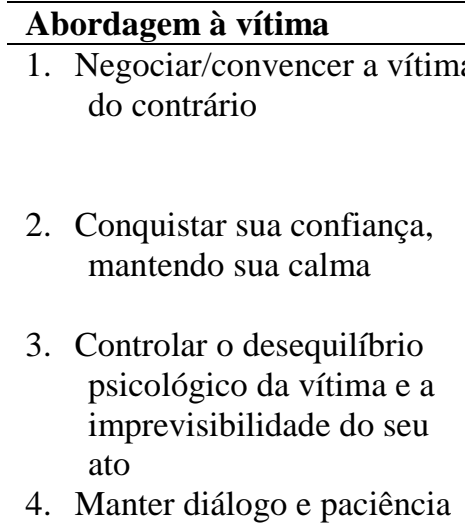

5. Desconhecer os motivos que levaram ao ato

6. Ser impotente diante da consumação do ato e falta de controle da ocorrência

7. Entender, ter empatia e manter-se neutro em relação às motivações da vítima

8. Ter cautela e responsabilidade na ação

9. Saber o que pode ou não comentar próximo à vítima

10. Manter atenção da vítima para atuação do salvamento

11. Lidar com a localização da vítima - altura

12. Conter a vítima

"É convencer a pessoa que aquele ato é errado e que ela pode ser feliz apesar de todos os problemas". Suj. 7 -

PM

"Convencê-lo a desistir". Suj. 95 - CBM

"Manter a vítima em estado de tranquilidade". Suj. 8 PM

"Conquistar a confiança da vítima". Suj. 129 - CBM

"O descontrole emocional da vítima". Suj. 14 - PM

"A imprevisibilidade das ações do potencial suicida".

Suj. 32 - CBM

"Manter o diálogo, qual assunto tratar, dar conselhos, falar de religião". Suj. 18 - PM

"Muita conversa e paciência". Suj. 12 - CBM

"O mais difícil é não saber o que a pessoa está passando naquele momento". Suj. 22 - PM

"Não se sabe quando a pessoa quer apenas aparecer ou quer se matar de fato". Suj. 102 - CBM

"A expectativa de não ter uma resposta benéfica e eficiente para solucionar a ocorrência". Suj. 104 - CBM

"A impotência em poder não ter evitado". Suj. 225 - PM

"Se conectar e tentar entender o que causa a tentativa de autoextermínio para poder de alguma forma ajudá-lo."

Suj. 10 - CBM

"Comprender a vítima e não julgar". Suj. 7 - PM

"É quando em posse de arma, qual atitude tomar, sem correr risco os terceiros". Suj. 2 - CBM

"Acho que é ter cautela em alguns tipos de ocorrência".

Suj. 159 - PM

"Saber o limiar do que se pode ou não comentar". Suj. 29

$-\mathrm{CBM}$

"A verbalização. Uma palavra errada e pode acontecer o imprevisível". Suj. 69 - PM

"Manter atenção da vítima para atuação do salvamento".

Suj. 60 - CBM

"Conseguir a atenção dela, fazendo isso, você consegue

salvar uma vida". Suj. 152 - PM

"Dificuldade operacional para possibilitar manobra". Suj.

$78-\mathrm{CBM}$

"A vítima estar em lugares altos" Suj. 77 - CBM

"Contenção da vítima e hospital especializado para conduzir". Suj. 16 - CBM

"A dificuldade na contenção aumenta conforme o meio em que ele escolhe para praticar o ato". Suj. 67 - PM

\section{Fatores sociais envolvidos no atendimento}

\begin{tabular}{llc} 
1. Lidar com o desespero da & "Os familiares em apuros, sem saber o que fazer, é muito & 65 \\
família & $\begin{array}{l}\text { sofrimento". Suj. 3 - PM } \\
\text { "O desespero da família e a falta de justificação perante o } \\
\text { ato". Suj. } 154-\text { CBM }\end{array}$ & \\
$\begin{array}{l}\text { 2. Lidar com a falta de Deus e } \\
\text { amor ao próximo }\end{array}$ & $\begin{array}{l}\text { "Não querem ouvir nada, parecem estar possessos. Falta } \\
\text { de amor ao próximo". Suj. 33 - PM } \\
\text { "A falta de Deus em sua vida". Suj. 65 - PM }\end{array}$ & - \\
\hline
\end{tabular}


(continuação Tabela 16)

\section{Fatores sociais envolvidos no atendimento}

3. Controlar a população curiosa

4. Lidar com a falta de apoio da família
"A população curiosa em volta do local da cena". Suj. 5

- CBM

“A interferência da população curiosa”. Suj. 73 - PM

"A família aceitar que a pessoa está passando por este tipo de problema." Suj. 7 - CBM

Aspectos operacionais e emocionais ligados ao profissional militar

1. Lidar com a falta de treinamento e de controle emocional da equipe

2. Lidar com a cena do local

3. Lidar com a falta de segurança, risco para os militares

4. Praticamente não há atendimento, apenas conduzir ao hospital ou à polícia

5. Lidar com a falta de hospital especializado para encaminhamento

6. Lidar com a demora do transporte (ambulância ou o

7. Nenhuma dificuldade próprio IML)

"Despreparo psicológico para lidar com a situação". Suj. $44-\mathrm{CBM}$

"'Falta de controle emocional da equipe". Suj. 340 - PM

"Cena do local, o que levou a pessoa àquele ato". Suj. $172-\mathrm{PM}$

"O impacto da cena, chegar ao local e verificar a real situação do problema”. Suj. 236 - PM

"O nível de estresse do indivíduo pode levá-lo a agir de forma agressiva, de maneira que ofereça um risco maior ao bombeiro". Suj. 90 - CBM

"Falta de segurança da guarnição". Suj. 22 - CBM

"Na verdade, é muito difícil. Nosso atendimento consiste basicamente em conduzir a pessoa ao hospital.

Praticamente não há atendimento quanto ao extermínio". Suj. 278 - PM

"A destinação da vítima após realizada a contenção da mesma". Suj. 18 - CBM

"O transporte, porque geralmente os minutos são uma eternidade para quem necessita”. Suj. 104 - PM

"Nenhuma dificuldade, registro normalmente. Só fico triste por ver aquele corpo e saber que sua alma está por toda eternidade no inferno". Suj. $162-$ PM

Em branco 147

215

Não categorizável

Fonte: Dados da pesquisa.

Na segunda questão aberta, foi questionado "o que mais facilita ou torna mais fácil o atendimento a pessoas em tentativa de autoextermínio?". As categorias identificadas, com base nos relatos, foram as mesmas temáticas observadas na questão sobre dificuldades: abordagem à vítima, fatores sociais envolvidos no atendimento e aspectos operacionais e emocionais dos militares (Tabela 17). Também compuseram as não categorizáveis aqueles relatos que o pesquisador não conseguiu entender ou não respondiam à questão. 
Tabela 17. Categorias e Subcategorias sobre Facilidades no Atendimento a Pessoas em Tentativa de Auto Extermínio elou Suicídio, Segundo os Participantes.

Categorias/subcategorias

Exemplos de relatos

PM BM

Abordagem à vítima

1. Manter diálogo convincente, ouvir, negociar

2. Ter calma, tranquilidade $\mathrm{e}$ paciência

3. Saber respeitar, compreender, ter empatia

4. Falar sobre motivação em relação à vida, ao amor, à família

5. Manter a atenção na vítima e obter a confiança para a ação do salvamento

6. Conhecer a história da vítima, causas da tentativa

7. Isolar o local de terceiros e/ou família

8. Falar de Deus

9. Manter-se neutro na ocorrência

10. Conter a vítima

11. Ter agilidade no atendimento

12. Ter conhecimento do local, riscos e meios possíveis para a tentativa

13. Lidar com o risco apenas da vítima, não colocando outros em risco

"Somente o acompanhamento, diálogo" Suj. 3 - PM

"Ter capacidade de persuasão para convencer o indivíduo a desistir do suicídio". Suj. 52 - CBM

"Facilita a calma e paciência do profissional". Suj. 21 - PM

"Devemos ter paciência e tranquilidade, além de passar confiança". Suj. 22 - PM

"Tratar o suicida com respeito e paciência". Suj. 9 - CBM

"Compreensão, empatia e paciência". Suj. 41 - PM

"Fazer lembrar da família, principalmente se tiver filhos".

Suj. 6 - PM; Suj. 73 - CBM

"Motivar a vítima a lutar pela vida e que vale a pena

continuar". Suj. 133 - CBM

"Ganhar a confiança e diálogo e esperar o descuido para

agir”. Suj. 86 - CBM

"Atenção naquela situação que a pessoa se encontra". Suj.

119 - PM

"Saber seu histórico, se já tentou outras vezes ou não e o

"Saber dos problemas que ela está passando, contexto

familiar, vícios". Suj. 97 - CBM

"Local isolado de terceiros". Suj. 35 - CBM

"Um ambiente reservado, longe dos curiosos". Suj. 59 - PM

"Falo de Jesus para ele". Suj. 162 - PM

"Tentar falar de Deus para ele". Suj. 52 - PM

"A impessoalidade no atendimento sem dúvida evita

qualquer análise e correlação de fatos e projeções para a vida pessoal". Suj. 146 - CBM

"Tratar como qualquer tipo de ocorrência: com profissionalismo e imparcialidade”. Suj. 30 - PM

"Diálogo e forma de conter o suicida de acordo com cada situação" Suj. 53 - CBM

"Poder operacional para conter a vítima". Suj. 99 - CBM

"Agilidade no atendimento". Suj. 76 - CBM

"A agilidade do serviço médico". Suj. 276 - PM

"Reconhecer o meio utilizado para a tentativa". Suj. 302 PM

"Conhecer o local e as possíveis formas que a vítima pode tentar o ato até onde esteja". Suj. 12 - CBM

"Quando o mesmo expõe só a si mesmo e não esteja de posse de armas". Suj. 2 - PM

"Se a vítima não tenta algo contra terceiros". Suj. 283 - PM

\begin{tabular}{|c|c|c|c|}
\hline \multicolumn{4}{|c|}{ Fatores sociais envolvidos no atendimento } \\
\hline $\begin{array}{l}\text { 1. Pedir a presença de algo } \\
\text { ou apoio a alguém que o } \\
\text { suicida gosta muito }\end{array}$ & $\begin{array}{l}\text { "Pessoas conhecidas e queridas da vítima" Suj. } 161 \text { - PM } \\
\text { "Oferecer algo que possa acalmá-lo durante o diálogo } \\
\text { (cigarros, bebidas, pessoas, etc.)". Suj. } 78 \text { - CBM } \\
\text { "O apoio da família". Suj. } 8 \text { - PM } \\
\text { "Informações de conhecidos ou familiares antes de iniciar a } \\
\text { conversa com a vítima." Suj. } 12 \text { - CBM }\end{array}$ & 17 & 10 \\
\hline 2. Ter religiosidade & $\begin{array}{l}\text { “A presença de Deus no coração das pessoas”. Suj. } 17 \text { - } \\
\text { CBM } \\
\text { "Religiosidade". Suj. } 46 \text { - PM }\end{array}$ & 6 & 1 \\
\hline
\end{tabular}


(continuação Tabela 17)

\begin{tabular}{|c|c|c|c|}
\hline Categorias/subcategorias & Exemplos de relatos & $\begin{array}{c}\mathbf{P M} \\
\text { F }\end{array}$ & $\begin{array}{c}\mathbf{B M} \\
\mathbf{F}\end{array}$ \\
\hline \multicolumn{4}{|c|}{ Aspectos operacionais e emocionais dos militares } \\
\hline $\begin{array}{l}\text { 1. Ter equipe bem treinada, } \\
\text { seguir protocolo, técnicas, } \\
\text { conhecimento }\end{array}$ & $\begin{array}{l}\text { "Ter base no conhecimento sobre o assunto". Suj. } 9 \text { - PM } \\
\text { "A equipe bem treinada". Suj. } 5 \text { - CBM }\end{array}$ & 18 & 26 \\
\hline 2. Ter controle emocional & $\begin{array}{l}\text { "Que o atendente tenha calma e controle emocional para } \\
\text { lidar com o inesperado, que tenha percepção da carga } \\
\text { emocional nessa situação". Suj. } 24 \text { - PM } \\
\text { "O que facilita o atendimento é o controle emocional. Acho } \\
\text { que os profissionais deveriam ter treinamento com psicólogo } \\
\text { para saber o que falar". Suj. } 45 \text { - PM } \\
\text { "O preparo psicológico para lidar e a escolha dos } \\
\text { argumentos". Suj. } 179 \text { - PM }\end{array}$ & 20 & 7 \\
\hline $\begin{array}{l}\text { 3. Imprevisível, não há } \\
\text { facilidade. }\end{array}$ & $\begin{array}{l}\text { "Não tem como avaliar! Cada ocorrência é cada ocorrência!" } \\
\text { Suj. } 44 \text { - CBM } \\
\text { "Não tem nada fácil, cada atendimento é diferente". Suj. } 88 \\
\text { - CBM } \\
\text { "Nada facilita. É o tipo de situação que choca a todos". Suj. } \\
171 \text { - PM }\end{array}$ & 13 & 6 \\
\hline $\begin{array}{l}\text { 4. Ter especialistas nas áreas } \\
\text { de altura, psicologia, } \\
\text { medicina, assistência } \\
\text { social e em negociação }\end{array}$ & $\begin{array}{l}\text { "Ter um profissional psicólogo conseguiria reverter a } \\
\text { ocorrência". Suj. } 167-\text { PM } \\
\text { "Um médico especialista no assunto para receber o } \\
\text { paciente". Suj. } 18 \text { - CBM }\end{array}$ & 14 & 6 \\
\hline $\begin{array}{l}\text { 5. Ter experiências } \\
\text { anteriores nas ocorrências } \\
\text { e compartilhá-las }\end{array}$ & $\begin{array}{l}\text { "As experiências vividas nas ocorrências, os fatos e as } \\
\text { causas". Suj. } 6 \text { - CBM } \\
\text { "A prática com ocorrências dessa natureza além do costume } \\
\text { de tratar com suicida em potencial". Suj. } 72 \text { - CBM } \\
\text { "Pelo cotidiano do policial que é acionado sempre para esse } \\
\text { tipo de atendimento". Suj. } 160 \text { - PM }\end{array}$ & 10 & 6 \\
\hline 6. Ter espiritualidade & $\begin{array}{l}\text { "Ter uma espiritualidade, acreditar em algo maior, algo } \\
\text { supremo e que temos nossa função no mundo". Suj. } 149 \text { - } \\
\text { CBM } \\
\text { "Deus na minha vida". Suj. } 65 \text { - PM }\end{array}$ & 4 & 2 \\
\hline 7. Ser otimista & $\begin{array}{l}\text { "O otimismo do profissional é importante no atendimento". } \\
\text { Suj. } 47 \text { - PM } \\
\text { "Ser sempre otimista em todas as circunstâncias". Suj. } 294 \text { - } \\
\text { PM }\end{array}$ & 4 & - \\
\hline Em branco & & 115 & 25 \\
\hline Não categorizável & & 19 & 4 \\
\hline
\end{tabular}

Fonte: Dados da pesquisa.

Na categoria de abordagem à vítima, a subcategoria mais citada, tanto na PM quanto no CBM, foi a necessidade de "manter um diálogo convincente, assim como a necessidade de ouvir a vítima e negociar sua vida”. Em segundo lugar, na PM, está o fato de que os militares precisam "ter calma, tranquilidade e paciência" para atender a ocorrência. Em terceiro, "saber respeitar, compreender, ter empatia". Já para o CBM, em segundo, "saber respeitar, compreender, ter empatia" e, em terceiro, "Ter calma, tranquilidade e paciência”. Na categoria fatores sociais, a subcategoria citada mais vezes em 
ambas as corporações foi a de "pedir a presença de algo ou apoio a alguém que o suicida gosta muito (amigos ou familiares)". Por fim, em relação aos aspectos operacionais e emocionais, a maioria dos policiais militares citou a necessidade do controle emocional da equipe como fator facilitador no atendimento às vítimas, assim como a necessidade de treinamentos, técnicas e conhecimento para lidar com o suicídio. Ter especialista na área para auxiliar no atendimento também apresentou frequências relativamente altas nessa categoria. No CBM, a subcategoria mais frequente foi "Ter equipe bem treinada", seguida do controle emocional da equipe.

\subsection{Considerações finais}

Os resultados deste estudo apontaram para um percentil mediano das respostas corretas da EMCS. Considera-se esse dado muito positivo, pois os participantes não possuíam treinamentos regulares na área de saúde mental, principalmente a PM, segundo dados obtidos na análise qualitativa. Maiores índices de acertos na EMCS estiveram associados a menos idade, gênero feminino, cargo de oficial e formação escolar superior ou mais alta.

Os itens com mais acertos nas respostas da EMCS foram os que abordavam a calma e a paciência que o profissional deve ter com a vítima; que não se deve ficar com raiva do suicida; e, se ele melhorou, está fora de risco. Esses resultados revelam mais conhecimento dos participantes nos temas. Os resultados quantitativos também corroboram as análises qualitativas, que apresentaram características semelhantes nos aspectos que facilitam o trabalho com a vítima de TAE, por exemplo, a necessidade de negociação com a vítima, habilidades de diálogo, calma e paciência por parte do militar para que a operação seja eficaz. 
Deve-se fazer uma ressalva sobre o item “a depressão é um diagnóstico óbvio, fácil de ser parcebido" que a maioria dos participantes errou. A maioria dos pesquisadores da temática considera que este item é verdadeiro, contrariando o gabarito oficial. Desta forma, os participantes teriam índices altos de acerto e não de erro.

Dois fatores da escala de Valores Pessoais (QVP-24) foram preditores de mitos e crenças sobre o suicídio: o fator hedonismo/materialismo predisse negativamente e o bemestar social foi preditor positivo. No entanto, a reduzida variância explicada observada sugere que variáveis não pesquisadas neste estudo devem ter influência sobre os mitos e as crenças.

Este estudo tem como ponto positivo o seu pioneirismo no que tange à temática de suicídio em amostras militares, sendo Portela (2012) o primeiro a investigar policiais do Corpo de Bombeiros, no Distrito Federal. Deve-se considerar que a finalidade de conhecer esse fenômeno em sua amplitude, identificando os mitos e as crenças que podem impactar a atuação do militar, pode auxiliar a construção de treinamentos e capacitações para desconstruir comportamentos baseados no senso comum e que podem prejudicar a eficácia da abordagem. Conclui-se que, dependendo dos valores pessoais, por exemplo, religioso ou aspectos como falta de controle emocional do profissional ou de treinamento técnico específico, podem levar a um atendimento ineficaz.

Entender a TAE como fingimento ou manipulação pode eliciar até mesmo sentimentos de raiva no socorrista e, em consequência, a retaliação na via contratransferencial, conforme proposto por Ouzouni e Nakakis (2009), Maltsberger (1996) e Freemouw et al. (1990), o que pode redundar em desfechos drásticos.

Considera-se, então, que as instituições de segurança devem oferecer suporte técnicocientífico aos profissionais que atuam diretamente nas situações de emergências. Ressaltase que os valores organizacionais também são estratégicos no atendimento humanizado e 
eficaz das situações de risco, apesar de não ter sido comprovada sua influência, do ponto de vista estatístico, nas análises com a EVO no presente estudo. 


\section{Capítulo 6}

\section{Discussão}

O objetivo principal da tese foi identificar os mitos e as crenças de profissionais militares (PM e CBM) que atendem chamados de socorro em casos de suicídio, bem como analisar preditores de mitos e crenças sobre o suicídio entre valores pessoais e organizacionais. Dessa forma, foi necessário proceder, primeiramente, à análise fatorial exploratória (AFE) da Escala de Mitos e Crenças sobre o Suicídio (EMCS), instrumento construído no contex to do estudo um.

A elaboração e a análise da estrutura fatorial da EMCS, com 32 itens e indicador de consistência interna muito satisfatório (alpha $=0,87$ ), foi uma contribuição relevante da presente tese. No entanto, uma limitação pode ser apontada: a EMCS foi validada em uma população muito jovem e sem experiência profissional, aspectos que caracterizam os estudantes universitários. Por outro lado, ao ser aplicada na amostra do estudo dois, composta de profissionais militares (PM e CBM), sua estrutura fatorial foi mantida e o alpha de Cronbach foi satisfatório, ainda que mais baixo $(0,70)$, aspecto que aponta a estabilidade de sua estrutura ao ser aplicada em duas amostras distintas.

No sentido de aprimorar pesquisas futuras, considera-se que a EMCS deve ser mais bem investigada em relação ao formato dicotômico da escala de respostas. O formato de resposta verdadeiro e falso parece limitar a correlação destas com outros instrumentos de avaliação psicológica. Sugere-se, ainda, a aplicação da EMCS em profissionais da área da saúde, ou seja, que a validação seja ampliada para outros segmentos sociais, preferencialmente em amostras probabilísticas.

Ressalta-se que a EMCS é uma escala pioneira, no contexto brasileiro, na investigação de mitos e crenças sobre o suicídio e pode auxiliar na sua identificação, 
propiciando atividades de capacitação e de pesquisas na área. Essa escala pode auxiliar na elaboração, no planejamento e na definição de ações educativas para os treinamentos operacionais de militares, por exemplo. A identificação de mitos e crenças pode auxiliar também na construção de estratégias de prevenção eficazes, pois pode partir do diagnóstico do próprio sujeito ou de grupos sociais. A construção de um instrumento de avaliação, tal como a EMCS, vai ao encontro de iniciativas de enfrentamento desse problema de saúde pública, pois, segundo dados da OMS, o suicídio está entre as dez principais causas de morte entre jovens adultos em todo o mundo (WHO, 2014).

Tal como afirmado, o estudo dois teve como objetivo principal identificar os mitos e as crenças de profissionais de segurança que atendem chamados de socorro em casos de suicídio, bem como analisar preditores de mitos e crenças sobre o suicídio entre valores pessoais e organizacionais. Quanto aos objetivos específicos, foi proposto verificar a associação entre variáveis pessoais - religião, nível hierárquico e de instrução, gênero, idade, situação conjugal dos profissionais - e as crenças e mitos sobre o suicídio, nas duas corporações militares de Goiás.

Diante desses objetivos, foram lançadas hipóteses e, com base nos resultados, algumas conclusões podem ser efetuadas. De acordo com os dados obtidos, pode-se afirmar que a hipótese de que esses profissionais possuem mitos e crenças a respeito do fato de que as pessoas que tentam suicídio não conseguem resolver seus problemas, têm problemas mentais, querem apenas chamar a atenção e são covardes - com base nos trabalhos de Freemouw et al. (1990), Osafo et al. (2011), Portela (2012) e Freitas e Borges (2014) - foi, de alguma forma, refutada. Isso porque os participantes acertaram mais de $60 \%$ dos itens, ao marcar como falsos aqueles que se referiam a essa hipótese: pessoas que tentam ou cometem suicídio não conseguem resolver seus problemas, têm problemas mentais, querem chamar a atenção e são covardes. Ademais, o escore médio da amostra foi 
igual a 24,85 (DP=3,3) na EMCS (cujo escore máximo seria 32), resultado considerado positivo, pois são profissionais que não tem formação específica na área de saúde.

Outra hipótese assinalava que variáveis pessoais como religião, nível hierárquico e situação conjugal dos profissionais teria influência sobre mitos e crenças dos participantes das duas corporações militares de Goiás. Os resultados indicaram a ocorrência de diferenças significativas dos escores médios de mitos e crenças sobre o suicídio, no que tange à instrução, ao gênero, à idade e à patente. Assim, percebeu-se que índices mais altos de acertos na EMCS, com diferenças estatísticas significativas, ocorreram em mulheres, militares mais jovens, com maior nível de escolaridade e nível hierárquico mais alto. É importante ressaltar que escores mais elevados na escala representam conhecimentos sobre o suicídio compatíveis com a literatura científica. Constatou-se, então, que militares oficiais, com escolaridade superior e/ou pós-graduação, com até 38 anos de idade e do sexo feminino parecem estar mais informados e atualizados sobre o tema. Não houve diferença significativa entre os respondentes considerando a situação conjugal e a religião. Além disso, não foram identificados estudos que pesquisaram essas associações, o que prejudicou a comparação desses resultados com outros trabalhos científicos.

Outra hipótese considerava que o profissional de atendimento de emergências é uma pessoa que sente, sofre e se afeta, sendo influenciado por seus valores pessoais e pelos valores da corporação. A hipótese de que os valores pessoais exercem influência sobre mitos e crenças a respeito do suicídio foi confirmada em parte, no que concerne aos fatores hedonismo/materialismo e bem-estar social, tendo sido o primeiro preditor negativo e o segundo, positivo, resultado coerente tendo em vista a definição de ambos os fatores. Deve-se considerar, ainda, que conhecer os valores e as características pessoais do grupo em estudo (policiais militares) facilita a construção de ações eficazes de socorro emergencial e, consequentemente, programas de prevenção e atenção em TAE. O estudo 
de Radhakrishnan e Andrade (2012) considera que ter conhecimento das variáveis pessoais dos profissionais é muito importante na elaboração de estratégias de treinamento, preventivas e de atuação, pois elas devem ser adaptadas aos dados demográficos específicos, além da necessidade de serem executadas conforme o contexto cultural e regional de um país.

Os valores organizacionais não foram relevantes e não estiveram associados com mitos e crenças, ao contrário do que foi observado por Kock (2010) em seu estudo com policiais. O autor identificou a influência da cultura organizacional e, em consequência, o contexto no qual ocorrem as experiências traumáticas e a forma como lidam com elas. Em muitos casos, a instituição policial não propicia os subsídios e o suporte que seus profissionais precisam para se recuperar de exposições traumáticas. As instituições estão acostumadas a cumprir os procedimentos-padrão e a maioria de seus membros é deixada sem estratégias para lidar com a sua vida emocional após a conclusão do trabalho.

É possível que aspectos metodológicos tenham exercido influência sobre esses resultados, na medida em que a escala escolhida para medir essa variável possa não ter sido a apropriada. Ademais, a opção por considerar os escores dos dois fatores oriundos da análise de componentes principais da EVO realizada com a amostra do presente estudo, que redundou no agrupamento dos cinco fatores originais em dois, pode ter interferido em eventuais efeitos da variável valores organizacionais sobre mitos e crenças.

Além da análise quantitativa, foram investigados, mediante questões abertas, aspectos facilitadores e dificultadores no atendimento a TAE, segundo os participantes. A análise dos relatos escritos foi agrupada em três categorias: abordagem à vítima, fatores sociais envolvidos no atendimento e aspectos operacionais e emocionais dos militares. Por sua vez, essas categorias foram organizadas em subcategorias. A análise qualitativa mostrou algumas atitudes que podem ser facilitadoras no atendimento a emergências no 
contexto de TAE, baseadas na experiência dos profissionais, como, por exemplo, manter diálogo convincente, ouvir, negociar, ter calma, tranquilidade e paciência, respeitar, compreender, ter empatia. Ademais, os grupos citaram o controle emocional da equipe como fator facilitador no atendimento às vítimas, assim como a necessidade de treinamentos, técnicas e conhecimento teórico para lidar com o suicídio. No que tange aos aspectos dificultadores, merecem destaque subcategorias como: saber o que pode ou não comentar próximo à vítima, lidar com a sua localização (altura) e com o desespero da família, controlar a população curiosa, gerenciar a demora do transporte (a ambulância ou o próprio IML).

Essas categorias apontam a complexidade do trabalho de responsabilidade dos militares no socorro a pessoas que ameaçam, tentam se suicidar ou se suicidam. De forma pertinente e com muita propriedade, os relatos verbais assinalaram o que eles precisam desenvolver em termos de habilidades de comunicação, pautadas na humanização e no respeito ao outro, para desempenhar melhor seu trabalho no contexto de TAE. Por outro lado, observaram-se, ainda, mitos e crenças no que se refere à religiosidade da pessoa que pensa em dar fim à própria vida: uma subcategoria relatou que uma estratégia eficaz seria falar de Deus para a vítima, mas isso pode pautar-se em valores do próprio profissional e ser contraproducente.

Fica evidente a importância de atividades de capacitação e de treinamento que desenvolvam ou aprimorem habilidades comunicacionais e éticas, visando, inclusive, prevenir sofrimento psíquico e desgaste emocional dos militares, tal como sugerido por Portela (2012). Outro aspecto de suma relevância é que o melhor preparo desses profissionais poderá ter influência positiva na eficácia da ação. Afinal, uma intervenção bem executada poderá ser efetiva e eficaz, com mais chances de resultar em não ocorrência de desfechos trágicos: o ato suicida. 
Assim, os relatos dos participantes permitem uma reflexão sobre como os militares estão sendo treinados para as abordagens e se estão aptos a lidar com situações que envolvem a mediação com familiares e/ou população em geral. Em relação a seus aspectos operacionais e emocionais, as duas corporações referiram as dificuldades impostas pela falta de capacitação e de controle emocional da equipe, apontando a necessidade de uma intervenção da instituição na melhoria do suporte organizacional. Tavares (2013) afirma que um dos desafios que se enfrenta na construção de estratégias para a prevenção do suicídio é o despreparo, tanto da família quanto da equipe, que acarretam interpretações simplistas do fenômeno, provocando reações de indignação e até mesmo de punição da vítima de TAE.

Tomadas em conjunto, as categorias identificadas revelaram, portanto, a carência de treinamentos e de suporte emocional aos profissionais. Considera-se de suprema importância a elaboração, o planejamento e a implantação de treinamentos que abarquem conhecimento técnico do assunto, que proporcionem a compreensão da situação da vítima, que reforcem a importância da assistência humanizada, além do suporte em mediação de conflitos (vítima e família).

Outro aspecto que merece reflexão se refere ao destacado por Portela (2012) em sua investigação, intitulada "O primeiro socorro na tentativa de suicídio", a partir dos aspectos relatados por bombeiros do Distrito Federal, indo ao encontro do exposto na literatura internacional sobre as operações de salvamento e de resgate (McMains \& Mullins, 2010). Quando os entrevistados descreveram o que faziam no primeiro socorro ao suicida, apresentaram homogeneidade intragrupo, o que remete ao conhecimento e ao cumprimento do Procedimento Operacional Padrão (POP) para pacientes psiquiátricos em geral. Essa diretriz operacional apresenta-se semelhante à utilizada nos EUA e corresponde ao proposto na literatura especializada para a ação na cena de crise (Greenstone, 2005; 
Hancerli, 2008; Lanceley, 2003, Wood, 2008). No entanto, há ausência de uma abordagem sistemática nesse POP no que se refere à negociação nos casos de TAE, como se pode observar ao compará-la com o modelo revisado de McMains e Mullins (2010). O que pode ser dito na negociação com um suicida vai depender da cena, do sujeito, do tempo e de outras condições (Portela, 2012), de modo que POPs rígidos podem não ser efetivos.

Ainda de acordo com esse autor, há necessidade de avaliações constantes das ações realizadas no primeiro socorro à TAE. No CBM-DF, as ações são implantadas de forma muito técnica, quando há demanda de intervenção no ambiente, mas sem planejamento no caso das intervenções pela interação verbal com o indivíduo em crise. Diante dessas ações de natureza verbal, questiona-se, aqui, se mitos e crenças não interferem na eficácia da ação, como, por exemplo, na subcategoria apresentada pelos militares goianos quanto a falar de Deus para a vítima.

Outro ponto que não pode ser negligenciado pela instituição se refere aos aspectos psicológicos e às emoções do profissional que trabalha com emergências. Pesquisadores (Heinsen et al. 1999; Danto, citado por Kock, 2010; e Nicoletti \& Spencer-Thoma, 1999) reforçam que ações de suporte emocional devem ser disponibilizadas aos militares, pois é muito provável que eles se deparem com tentativas ou suicídios consumados, que podem desencadear reações emocionais contundentes, tanto na cena do ato suicida quanto em momentos posteriores à experiência, já nos períodos de folga, muitas vezes similares a quadros de estresse pós-traumático. O militar pode se sentir culpado de eventual fracasso ocorrido na operação. Portela (2012) verificou, em seu estudo com bombeiros sobre suas emoções no atendimento às TAEs, que a maioria deles citou a satisfação nos casos de sucesso da operação e a sensação de impotência quando não conseguiam efetuar o socorro. O autor concluiu que o profissional socorrista precisa de informações e treinamentos para práticas preventivas e atuação diante de TAEs, pois suas crenças e mitos podem 
influenciar negativamente a sua atuação. $\mathrm{O}$ autor considera, ainda, que os altos índices de TAE se caracterizam como uma das grandes emergências psicológicas e psiquiátricas, por iniciar um processo que pode causar danos graves à saúde, ou mesmo a morte. Dessa forma, tanto profissionais de saúde mental, como de segurança pública, ainda que com treinamentos em emergências, "ao presenciar o momento de ocorrência de uma TAE, podem questionar a sua própria capacidade de operar a fim de favorecer a resolução efetiva dessa crise" (Portela, 2012, p. 22).

Tavares (2013) afirma que estar diante de alguém em situação de TAE pode provocar sentimentos muito confusos. Além disso, considera que, quando o profissional desqualifica a tentativa ou o desejo de morte do paciente ("é manipulação"; "é só para chamar atenção"), desqualifica o sofrimento, (“ele não tem motivo para estar assim"), suas dificuldades e vulnerabilidades ("se quisesse mesmo, ele já tinha resolvido isso"), "pode ser considerado uma forma sutil de aversão e ressentimento" (Tavares, 2013, p. 55). O autor avalia que, nesses casos, se trata de uma desqualificação dos sentimentos da vítima; ressalta, também, que a melhor forma de ajudar uma pessoa que fez ou está considerando tentar suicídio é ouvindo e desenvolvendo uma sensibilidade para a sua situação, como apresentado pelos militares nos aspectos facilitadores do atendimento às TAEs da presente pesquisa. Nesse sentido, levar a sério uma ameaça de suicídio é sempre muito importante, independentemente de sua gravidade.

Este trabalho mostrou a importância da aprendizagem compartilhada para habilitar os profissionais a refletir e a aprender em relação às complexidades da saúde mental e às implicações das diferentes formas de atuação na prestação de atendimento às vítimas de TAE. Ressalta-se a importância de se desenvolver uma abordagem sistemática de avaliação e gestão de suicídio que possa ser eficaz em uma diversidade de configurações da rede de serviços de saúde, tanto na esfera da saúde mental quanto em unidades gerais 
(como as unidades de emergência em hospital-geral). A avaliação eficaz dos riscos e a gestão de riscos é um componente importante das práticas em saúde, sendo vital para pessoas em crise e em situação de risco (Bertolote et al., 2010; Deuter et al., 2013).

Destaca-se que ações de prevenção ao suicídio configuram um continuum, envolvendo instituições governamentais e não governamentais: abarcam desde níveis promocionais de saúde (em escolas, locais de trabalho, comunidades) até aquelas de nível terciário de atenção (como hospitais gerais e unidades da área de saúde mental). As ações de policiais como bombeiros e militares se inserem nesse continnum e nessa rede, assumindo contornos tanto preventivos como assistenciais. Após uma ação exitosa em TAE, por exemplo, a intervenção de equipes de saúde é necessária, para o acompanhamento e o atendimento às demandas e às queixas da pessoa que não consumou o ato a partir da ação dos militares, mas que pode manter em risco, se não receber atenção apropriada e de qualidade, voltada para os motivos que ocasionaram o episódio de TAE.

Em suma, o comportamento suicida pode ser prevenido e, para isso, o planejamento e a criação de programas articulados em rede, no contexto de políticas públicas, envolvendo equipes interdisciplinares, são extremamente importantes. A prevenção do comportamento suicida é um grande desafio não só para a Psicologia, mas para outras áreas do conhecimento e para toda a sociedade.

Este trabalho configura-se como uma contribuição relevante, sendo essa luta de todos - profissionais, pesquisadores, educadores - que pensam e atuam na temática do suicídio, alvo das políticas públicas, em especial a de saúde. 


\section{Referências}

Adorno, T. W., Frenkel-Brunswik, E., Levinson, D. J., \& Sanformd, R. N. (1950). The authoritarian personality. New York: John Wiley \& Sons.

Altemeyer, B. (1981). Right-wing authoritarianism. Manitoba: Manitoba University Press.

Altemeyer, B. (1988). Enemies of freedom. San Francisco: Jossey-Bass.

Altemeyer, B. (1996). The authoritarian specter. Cambridge, MA: Harvard University Press.

Andolfi, M., \& Angelo, C. (1989). Tempo e mito em terapia familiar. Porto Alegre: Artes Médicas.

Arendt, H. (1972). Entre o passado e o futuro. São Paulo: Perspectiva.

Bando, D. H. (2012). Suicide rates and trends in São Paulo, Brazil, according to gender, age and demographic aspects: a join point regression analysis. Revista Brasileira de Psiquiatria, 34, 286-293.

Bando, D. H., \& Lester, D. (2014). An ecological study on suicide and homicide in Brazil. Ciência e Saúde Coletiva, 19 (4), 1179-1189.

Bandura, A. (1973). Aggression: a social learning analysis. Englewood Cliffs, NJ: Prentice Hall.

Bastos, A. V. S., \& Gondim, M. G. (2010a). Suicídio e trabalho. Revista Administração Contemporânea-RAC, 14 (5), 939-948.

Bastos, A. V. B., \& Gondim, S. M. G. (Eds.). (2010b). O trabalho do psicólogo no Brasil. Porto Alegre: Artmed.

Beattie J. (1980). Introdução à antropologia social. São Paulo: Companhia Editora Nacional. 
Bernardes, S. S., Turini C. A., \& Matsuo, T. (2010). Perfil das tentativas de suicídio por sobredose intencional de medicamentos atendidas por um Centro de Controle de Intoxicações do Paraná, Brasil. Cadernos de Saúde Pública, 26(7), 1366-1372.

Bertolote, J. M., Santos, M. C. de., \& Botega, J. N. (2010). Detecção do risco de suicídio nos serviços de emergência psiquiátrica, Revista Brasileira de Psiquiatria, 32(2), S87S95.

Bicudo, H. (2000, set./dez.). A unificação das polícias no Brasil. Estudos Avançados, 14 (40), 91-106.

Botega, N. J. (2004). Comportamento suicida: como preveni-lo. A Força Policial, 44, 2940.

Botega, N. J., Werlang, B. G., Cais, C. F. S., \& Macedo, M. M. K. (2006). Prevenção do comportamento suicida. Psico, 37, 213-220.

Canova, K. R., \& Porto, J. B. (2010). O impacto dos valores organizacionais no estresse ocupacional: um estudo com Professores de Ensino Médio. Revista de Administração Mackenzie, 11(5), 4-31.

Carvalho, A. (2005). Geisel, Figueiredo e a liberalização do Regime Autoritário (19741985). Revista de Ciências Sociais, 48(1), 115-147.

Cassorla, R. M. S. (2004). Suicídio e autodestruição humana. Em B. G. Werlang \& J. N. Botega (Orgs.), Comportamento suicida (pp. 21-33). Porto alegre: Artmed.

Cassorla, R. M. S. (2005). O que é suicídio? São Paulo: Brasiliense.

Conte, M. (2012). Programa de prevenção ao suicídio: estudo de caso em um município do sul do Brasil. Ciências e Saúde Coletiva, 17(8), 2017-2026.

Cronbach, J. L. (1996). Fundamentos da testagem psicológica. Porto Alegre, RS: Artes Médicas.

Deal, T. E., \& Kennedy, A. A. (1982). Corporate cultures: the rites and rituals of corporate life. London: Penguin Books. 
D’Assumpção, E. A., D’Assumpção, G. M., \& Bessa, H. A. (1984). Morte e suicídio: uma abordagem multidisciplinar. Petrópolis: Vozes.

Da Costa, J. B. (2000). Visões sociais de democracia: um estudo psicossociológico dos significados da democracia. Tese de Doutorado não publicada, Curso de Pós-graduação em Psicologia Social, Pontifícia Universidade Católica de São Paulo, São Paulo.

Dejours, C., \& Bégue, F. (2010). Suicídio e trabalho: O que fazer? Brasília: Paralelo 15.

Deschamps, J. C., \& Devos, T. (1993). Valeurs, cultures et changement. Intercultures, 1, 17-28.

Deuter, K., Galley, P., Champion, A., Gordon, A., Halczuk, T., Jackson, A. et al. (2013). Risk assessment and risk management: developing a model of shared learning in clinical practice. Advances in Mental Health, 11(2), 157-166.

Durkheim, E. (1982). O suicídio - um estudo sociológico. Rio de Janeiro: Zahar.

Feldman, S. (2003). Enforcing social conformity: a theory of authoritarianism. Political Psychology, 24, 41-73.

Fernandes, F. (1973). Política e segurança. São Paulo: Alfa-Omega.

Ferreira, M. C., \& Assmar, E. M. L. (2008). Cultura organizacional. Em M. M. Siqueira (Org.) Medidas do comportamento (pp. 125-138). São Paulo: Artmed.

Ferreira, V. R. T., \& Trichês, V. J. S. (2014). Epidemiological profile of suicide attempts and deaths in a Southern Brazilian city. Psicologia, 45(2), 219-227.

Field, A. (2009). Descobrindo a estatística usando SPSS (L. Vilali, Trad.). Porto Alegre: Artmed. (Obra original publicada em 2005).

Freitas, A. P. A. de., \& Borges, L. M. (2014). Tentativas de suicídio e profissionais de saúde: significados possíveis. Estudos e Pesquisas em Psicologia, 14(2), 560-577.

Fonseca, J. S., \& Martins, G. A. (1996). Curso de estatística. São Paulo: Atlas. 
Freemouw, W. J., Perczel, M., \& Ellis, T. E. (1990). Suicide risk-assessment and response guidelines. USA: Pergamon Press.

Fukumitsu, K. (2005). Suicídio e psicoterapia: uma visão gestáltica. Campinas: Livro Pleno.

Greenstone, J. L. (2005). The elements of police hostage and crisis negotiations: critical incidents and how to respond to then. New York: The Haworth Press.

Goiás (Estado). (1989). Constituição Estadual de Goiás. Organização da Diretoria Parlamentar e Diretoria Legislativa. Goiânia: Assembleia.

Guimarães, J. G., Torres, A. R. R., \& Faria, M. V. de. (2005). Democracia e violência policial: o caso da Polícia Militar. Psicologia em Estudo, 10(2), 165-173.

Guimarães, J. G., Torres, A. R. R., \& Mendonça, H. (2012). Assédio moral e bem-estar: um estudo exploratório em corporações militares. Em T. M. Vieira (Orgs.), Psicologia e Contemporaneidade: apontamentos de um saber em profusão (pp. 11-30). Vila Velha, ES: Opção Editora.

Hair, J., Black, W., Babin, B., Anderson, R., \& Tatham, R. (2009). Análise multivariada de dados. Porto Alegre: Bookman.

Hancerli, S. (2008). Negotiation, communication and decision strategies used by hostage/Crisis negotiators. ProQuest Dissertations and Theses: ProQuest.

Heinsen, D. L., Kinzel, T., \& Ramsey, R, (1999). Suicide and law enforcement: is suicide intervention a necessary part of police training? Paper presented at the Suicide and Law Enforcement conference, Quantico: VA.

Hochman, B., Nahas, F. X., Oliveira Filho, R. S., \& Ferreira, L. M. (2005). Desenhos de pesquisa. Acta Cirurgica Brasileira, 20(2), 2-9.

Hofstede, G. (1980). Culture's consequences: international differences in work-related values. Beverly Hills: Sage.

Hofstede, G. (1998). Attitudes, values and organizational culture: Disentangling the concepts. Organization Studies, 19(3), 477-492. 
Hofstede, G., Neuijen, B., Ohayv, D., \& Sanders, J. (1990). Measuring organizational cultures: a qualitative and quantitative study across twenty cases. Administrative Science Quarterly, 35(2), 286-316.

Holmes, D. S. (2004). Psicologia dos transtornos mentais. Porto Alegre: Artes Médicas.

Inglehart R. (1977). The silent revolution. Princeton: Princeton University.

Inglehart R. (1994). Modernización y post-modernización: la cambiante relación entre el desarrollo econômico, cambio cultural y político. Em J. D. Nícolas, R. Inglehart (Eds.), Tendencias mundiales de cambio en los valores sociales y políticos (pp. 157-170). Madrid: Fundesco.1

Krech, D., Crutchfied, R. S., \& Ballachey, E. L. (1975). O indivíduo na sociedade. São Paulo, SP: Pioneira. (Originalmente publicado em 1962).

Kock, B. J. (2010). The psychological impact on police officers of being first responders to completed suicides. Journal of Police and Criminal Psychology, 25, 90-98.

Lanceley, F. J. (2003). On-scene guide for crisis negotiators. Flórida, EUA: CRC Press LCC.

Laros, J. A. (2012). O uso da análise fatorial: algumas diretrizes para pesquisadores. Em: L. Pasquali (Org.), Análise fatorial para pesquisadores. Brasília, DF: LabPAM.

Lazzarini, E. R., \& Viana, T. de. (2006). O corpo em psicanálise. Psicologia Teoria e Pesquisa, 22(2), 241-250.

Leite, M. A. R., Nogueira, F. A. N., Melo, G. C., Paiva, I. R. A., Santos, M. C. C., \& Miranda, R. C, T. (2011). Perfil epidemiológico de pacientes que tentaram suicídio no Brasil. Percurso Acadêmico, 1(1), 175-176.

Lima, M. E. (1997). Valores, participação política, atitudes face a democracia e ao autoritarismo: uma análise da socialização política dos universitários da Paraíba. Dissertação de Mestrado não publicada, Universidade Federal da Paraíba, João Pessoa, Pernambuco. 
Lima, M. E., \& Camino, L. (1995). A política na vida de estudantes universitários: uma análise em termos de espaço político e de valores. Em M. J. L. Silva (Org.), Iniciados (pp. 11-35). João Pessoa: Editora Universitária.

Lins, S., Poeschl G., Lima, T. J. S. de., Souza, L. E. C. de. \& Pereira, C. R. (2016). Adaptation and validation of the psychosocial values questionnaire to the context of Brazilian and Portuguese teenagers. Psicologia: Reflexão e Crítica 29(12). Doi 10.1186/s41155-016-0013-0

Löwy, M. A. (1995). Ideologias e ciência social. São Paulo: Cortez.

McMains, M. J. \& Mullins, W. C. (2010). Crisis negotiations: managing critical incidents and hostage situations in law enforcement and corrections ( $4^{\mathrm{a}} \mathrm{ed}$.). New Providence, EUA: Matthew Bender \& Company Inc.

Maio, G.R., Olson, J. M., Allen, L., Bernard. M. (2001). Addressing discrepancies between values and behavior: The motivating effect of reasons. Journal of Experimental Social Psychology, 37, 104-117.

Maltsberger, J. T. (1996). Countertransference hate in the treatment of suicidal. Arch Gen Psychiatry, 30 (5), 625-633.

Meleiro, A., Teng C. T., \& Wang, Y. P. (2004). Suicídio: estudos fundamentais. São Paulo: Segmento Farma.

Minayo, M. C. S. (2012). Trends in suicide mortality among Brazilian adults and elderly, 1980-2006. Revista de Saúde Pública, 46(2), 300-309.

Minayo, M. C. S., \& Cavalcante, F. G. (2015). Tentativas de suicídio entre pessoas idosas: revisão de literatura (2002/2013). Ciência \& Saúde Coletiva, 20(6), 1751-1762.

Ministério da Saúde (2006). Prevenção do suicídio: manual dirigido a profissionais das equipes de saúde mental. Campinas: Unicamp.

Montenegro, B. F. de. S. P. (2012). O julgamento clínico do risco de suicídio. Tese de doutorado não publicada, Universidade de Brasília, Brasília, Distrito Federal. 
Nicoletti, J., \& Spencer-Thomas, S. (1999). Contamination of cop: secondary traumatic stress of officers responding to civilian suicide. Paper presented at the Suicide and Law Enforcement conference, Quantico, VA.

Nonaka, I. \& Takeuchi, H. (1997). Criação do conhecimento na empresa. Rio de Janeiro: Campus.

O’Carroll, P. W., Berman, A. L., Maris, R. W., Moscicki, E. K., Tanney, B. L., \& Silverman, M. (1996). Beyond the Tower of Babel: a nomenclature for suicidology. Suicide Life Threat Behavior, 26(3), 237-252.

OMS - Organização Mundial de Saúde. (2000). Prevenção do suicídio: um manual para médicos clínicos gerais. Genebra: Organização Mundial de Saúde.

OMS - Organização Mundial de Saúde. (2009). Preventing suicide: a resource for police, firefighters and other first line responders. Genebra: Organização Mundial de Saúde.

Oesterreich, D. (2005). Flight into security: a new approach and measure of the authoritarian personality. Political Psychology, 26, 275-297.

Oliveira, A.F., \& Tamayo, A. (2004, abr./maio./jun.). Inventário de perfis de valores organizacionais. RAUSP - Revista de Administração da Universidade de São Paulo, 39(2), 129-140.

Osafo, J., Hjelmeland, H., Akotia, C. S., \& Knizek, B. L. (2011). Social injury: an interpretative phenomenological analysis of the attitudes towards suicide of lay persons in Ghana. International Journal of Qualitative Studies on Health and Well-being, 6(4), 8708 .

Ouzouni, C., \& Nakakis, K. (2009). Attitudes towards attempted suicide: the development of a measurement tool. Health Science Journal, 3(4), 222-231.

Paula e Silva, J. M. A de (2001). Cultura escolar, autoridade, hierarquia e participação: alguns elementos para reflexão. Cadernos de Pesquisa, 112, 125-135.

Portela, C. E. da S. (2012). O primeiro socorro na tentativa de suicídio: decisões e estratégias de intervenção em crise. Dissertação de Mestrado não publicada, Universidade de Brasília, Brasília, Distrito Federal. 
Paschoal, T., \& Soraggi, F. (2011). Relação entre bem-estar no trabalho, valores pessoais e oportunidades de alcance de valores pessoais no trabalho. Estudos e Pesquisa em Psicologia, 11(2), 614-632.

Pasquali, L. (2003). Psicometria: teoria dos testes na psicologia e na educação. Petrópolis: Vozes.

Paz, M. G. T., \& Tamayo, A. (2004). Perfil cultural das organizações. In A. Tamayo (Ed.). Cultura e saúde nas organizações. Porto Alegre: Artmed.

Pereira, C., \& Camino, L. (1999). Proposta de um modelo psicossociológico para o estudo das atitudes políticas de estudantes universitários: uma análise em termos de valores materialistas e pós-materialistas. Em M. F. V. Souza (Ed.), Iniciados (pp. 427-440). João Pessoa, PB: Editora Universitária.

Pereira, C., Camino, L., \& Costa J. B. (2004). Análise fatorial confirmatória do Questionário de Valores Psicossociais - QVP-24. Estudos de Psicologia, 9(3), 505-512.

Pereira, C., Camino, L., \& Costa, J. B. (2005). Um estudo sobre a integração dos níveis de análise dos sistemas de valores. Psicologia: Reflexão e Crítica, 18, 16-25.

Pereira, C., Lima, M. E., \& Camino, L. (2001). Sistemas de valores e atitudes democráticas de estudantes universitários de João Pessoa. Psicologia: Reflexão e Crítica, 14, 177-190.

Pereira C., Ribeiro A. R. C., \& Cardoso, S. J. (2004). Envolvimento nos direitos humanos e sistema de valores. Psicologia em Estudo, (9), 55-65.

Pereira C., Torres A. R. R., \& Barros, T. S. (2004). Sistemas de valores e atitudes democráticas de estudantes universitários. Psicologia: Teoria e Pesquisa, 20, 1-10.

Pincus, L., \& Dare, C. (1981). Psicodinâmica da família. Porto Alegre: Artes Médicas.

Porto, J. B, \& Tamayo, A. (2007). Estrutura dos valores pessoais: a relação entre valores laborais e gerais. Psicologia: Teoria e Pesquisa, 23(1), 63-70.

Pridmore, S. (2011). Medicalisation of suicide. The Malaysian Journal of Medical Sciences, 18(4), 78-83. 
Radhakrishnan, R., \& Andrade, C. (2012). Suicide: an Indian perspective. Indian Journal of Psychiatry, 54(4), 304-319.

Ramos, I. N. B., \& Falcão, E. B. M. (2011). Suicide: a little-known topic in medical training. Revista Brasileira de Educação Médica, 35(4), 507-516.

Richardson, R. J., Peres, J. A., Wanderley, J. C. V., Correia, L. M., \& Peres, M. H. (1999). Pesquisa social: métodos e técnicas. São Paulo: Atlas.

Rodgers, P. L., Sudak, H. S., Silverman, M. M., \& Litts, D. A. (2007). Evidence-based practices project for suicide prevention. Suicide and Life-Threatening Behavior, 37(2), 154-164.

Rokeach, M. (1981). Crenças, atitudes e valores. São Paulo: Interciência.

Rousseau, D. M. (1990). Assessing organizational culture: the case for multiple methods. Em B. Schneider (Ed.). Organizational climate and culture (pp. 153-192). San Francisco: Jossey-Bass.

Rudd, D. M., Berman, A. L. Joiner, T. E. Jr., Nock, Silverman, M. M., Mandrusiak, M., Orden, K. V, \& Siverman, M. M. (2006). Warning signs for suicide: Theory, research, and clinical applications. Suicide and Life-Threatening Behaviour, 36(3), 255-262.

Sagie, A., Elizur, D., \& Koslowsky, M. (1996). Work values: a theoretical overview and a model of their effects. Journal of Organizational Behavior, 17, 503-514.

Schwartz, S. H. (1992). Universals in the content and structure of values: theoretical advances and empirical tests in 20 countries. Advances in Experimental Social Psychology, 25, 1-65.

Schwartz, S. H. (1994). Are there universal aspects in the structure and contents of human values? Journal of Social Issues, 50, 19-45.

Schwartz, S. H. (2012). An overview of the Schwartz theory of basic values. Online Readings in Psychology and Culture, 2 (1). http://dx.doi.org/10.9707/2307-0919.1116.

Schwartz, S. H., \& Bilsky, W. (1990, May). Toward a theory of the universal content and structure of values: Extensions and cross-cultural replications. Journal of Personality and Social Psychology, 58 (5), 878-891. http://dx.doi.org/10.1037/0022-3514.58.5.878. 
Schein, E. (1986). Organizational culture and leadership. San Francisco: Jossey Bas.

Smith, A. G., \& Winter, D. G. (2002). Wing authoritarism, party identification, and attitudes toward feminism in student evaluations of the Clinton-Lewinsky story. Political Psychology, 23, 355-383.

Stoppino, M. (1993). Autoritarismo. Em N. Bobbio, N. Matteucci \& G. Pasquino (Eds.), Dicionário de política. 5. ed. Brasília: Editora da UnB.

Tamayo, A. (1996). Valores organizacionais. Em A. Tamayo, J. E. Borges-Andarde \& W. Codo (Eds.), Trabalho, organização e cultura (pp. 175-194). São Paulo: Capital gráfica editora Ltda.

Tamayo, A. (1999). Valores e clima organizacional. Escola, saúde mental e trabalho (pp. 241-269). Brasília: Editora UnB.

Tamayo, A. (2000). Prioridades axiológicas e satisfação no trabalho. Revista de Administração da Universidade de São Paulo, 35(2).

Tamayo, A. (2004). Cultura e saúde nas organizações (1. ed.). Porto Alegre: Artmed.

Tamayo, A. (2005). Valores organizacionais e comprometimento afetivo. RAM-Revista de Administração Mackenzie, Sinmes, 192-213.

Tamayo, A. (2008). Valores organizacionais. Em M. M. M. Siqueira (Org.), Medidas do comportamento organizacional (pp. 309-340). Porto Alegre: Artmed.

Tamayo, A., \& Borges, L. D. O. (2001). Valores del trabajo y valores de las organizaciones. Psicologia social de los valores, 325-352.

Tamayo, A., \& Gondim, M. G. C. (1996). Escala de Valores Organizacionais. Revista de Administração, 31(2), 62-72.

Tamayo, A., \& Mendes, A. M. (1999). Inventário de valores organizacionais. Estudos de Psicologia, 5(2), 289-315. 
Tamayo, A., Mendes, A. M., \& Paz, M. G. T. (2000). Inventário de valores organizacionais. Estudos de Psicologia, 5 (2), 289-315.

Tamayo, A., \& Schwartz, S. (1993). Estrutura motivacional dos valores. Psicologia: Teoria e Pesquisa, 9, 329-348.

Tavares, M. (2013). Desafio doSuicídio: o luto dos sobreviventes. Em Conselho Federal de Psicologia. O suicídio e os desafios para a psicologia (pp. 43-58). Brasília: CFP.

Weber, M. (1944). Economia y sociedad. México: Fondo de Cultura Económica.

Werlang, B. G., \& Botega, N. J. (2004). Introdução. Em B. G. Werlang \& J. N. Botega (Orgs.), Comportamento suicida (pp. 17-18). Porto Alegre: Artmed.

Werlang, B. G., Macedo, M. M., \& Krüger, L. L. (2004) Perspectiva psicológica. Em N. J. Botega \& B. S. G. Werlang (Orgs.), Comportamento suicida (pp. 45-58). Porto Alegre: Artmed.

Wood, F. R. (2008). Relational communication in negotiation interaction. ProQuest Dissertations and Theses: ProQuest.

WHO - World Health Organization (2014). Global epidemiology of suicide and suicide attempts. Retirado em 22 de março de 2015, do site http://apps.who.int/iris/bitstream/10665/131056/1/9789241564779_eng.pdf?ua.

WHO - World Health Organization (2013). Suicide rates, by gender, Brazil, 1980-2008. Retirado em $1^{\circ}$ de agosto de 2014 , do site http://www.who.int/mental_health/prevention/suicide/suicideprevent/en/.

Xausa, I. A. M. (1986). A psicologia do sentido da vida. Petrópolis: Vozes. 
Anexos 


\section{Anexo A - Estudo 1}

\section{Termo de Consentimento para Participação em Pesquisa}

Convido você a participar da pesquisa "Mitos e crenças sobre o suicídio: visão de profissionais de segurança". Esta pesquisa é de responsabilidade de Juliany G. Guimarães de Aguiar e Marcelo Tavares, pesquisadores do Programa de Pós-Graduação em Psicologia Clínica e Cultura da Universidade de Brasília.

Este estudo tem como objetivo investigar como os futuros profissionais que atendem emergências de suicídio entendem esse fenômeno e como lidam com ele no dia a dia de suas atividades.

Conhecer melhor a prática de diversos serviços que tratam com pessoas com risco de suicídio ou com comportamentos suicidas é fundamental para orientar as instituições acerca do tipo de treinamento e suporte necessário para o exercício de cada profissão.

Caso concorde com sua participação, você será solicitado(a) a responder um questionário composto por questões objetivas. Você receberá todos os esclarecimentos necessários antes, durante e após a finalização da pesquisa. Asseguramos que os dados serão analisados apenas em grupo e que seu nome ou seus resultados pessoais são sigilosos e não serão divulgados. Será mantido o mais rigoroso sigilo mediante a omissão total de informações que permitam identificá-lo(a).

Caso tenham qualquer dúvida em relação à nossa pesquisa, podem entrar em contato conosco através dos telefones indicados abaixo:

Juliany Guimarães

Profa. Puc Goias/Psicologia

Doutoranda PPG-PsiCC/IP/UNB

(62) 98138-0496
Marcelo Tavares

Orientador PPG-PsiCC/IP/UNB

(61) $98111-1819$ 
Termo de Consentimento Livre, após Esclarecimento

Diante do exposto eu, declaro que estou ciente das informações recebidas e que concordo com a minha participação na pesquisa "Mitos e crenças sobre o suicídio: visão de profissionais de segurança", descrita no verso da folha anterior. Atesto que tive a possibilidade de lê-lo e obter os esclarecimentos necessários. Estou ciente de que terei a oportunidade de entrar em contato com os pesquisadores posteriormente, em outro momento, caso eu sinta a necessidade de obter novos esclarecimentos a respeito desta pesquisa.

de de 2016.

Assinatura do Participante

Documento de Identidade 


\section{Anexo B - EMCS original - Estudo 1}
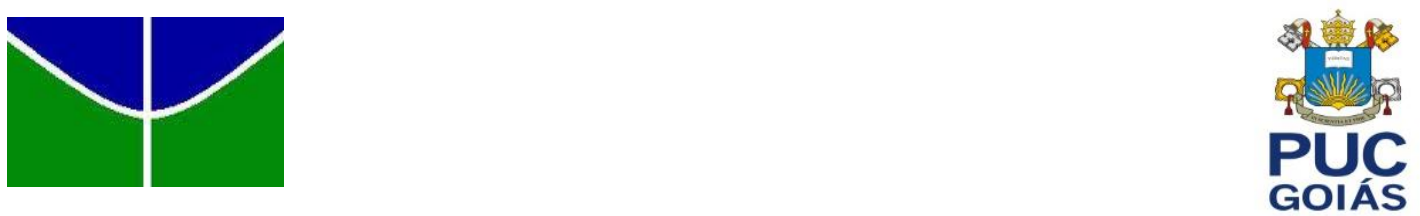

Este questionário é composto por afirmativas que objetivam investigar como os futuros profissionais da área de saúde percebem o tema "suicídio". Para participar, basta escolher a resposta que melhor representa sua opinião.

Nos itens abaixo, marque $\mathbf{V}$ se achar a ideia do item verdadeira ou $\mathbf{F}$ se achar que o item expressa uma ideia falsa.

\begin{tabular}{|c|c|c|}
\hline $\mathbf{V}$ & $F$ & $\begin{array}{l}\text { 1. A maioria dos suicidas procuraram serviços de saúde poucos meses ou semanas } \\
\text { antes de fazer a tentativa. }\end{array}$ \\
\hline $\mathbf{V}$ & $\mathrm{F}$ & 2. O impulso suicida é agudo e passageiro. \\
\hline $\mathbf{V}$ & $\mathrm{F}$ & $\begin{array}{l}\text { 3. A tentativa de suicídio representa uma vontade de aparecer, de chamar a } \\
\text { atenção. }\end{array}$ \\
\hline $\mathbf{V}$ & $\mathrm{F}$ & 4. A tentativa de suicídio é uma manipulação. \\
\hline $\mathbf{V}$ & $\mathrm{F}$ & 5. Uma vez suicida, a pessoa será sempre suicida. \\
\hline $\mathbf{V}$ & $\mathrm{F}$ & $\begin{array}{l}\text { 6. Quem faz planejamentos ou pensa em diferentes maneiras de provocar a própria } \\
\text { morte está pior do que quem tem apenas vontade de morrer sem planejamento. }\end{array}$ \\
\hline $\mathbf{V}$ & $\mathrm{F}$ & 7. A tendência suicida é hereditária, passa de geração a geração. \\
\hline $\mathbf{V}$ & $\mathrm{F}$ & 8. As pessoas que ameaçam, não se matam. \\
\hline $\mathbf{V}$ & $\mathrm{F}$ & 9. Quem realmente quer se matar, não avisa, se mata da primeira vez. \\
\hline $\mathbf{V}$ & $\mathrm{F}$ & 10. Ele tomou só aspirina. Na verdade, não queria morrer. \\
\hline $\mathbf{V}$ & $\mathrm{F}$ & 11. A tentativa de suicídio representa um pedido desesperado de ajuda. \\
\hline $\mathbf{V}$ & $\mathrm{F}$ & 12. Quem se mata, queria morrer mesmo. \\
\hline $\mathbf{V}$ & $\mathrm{F}$ & $\begin{array}{l}\text { 13. Via de regra, é mais seguro pensar que quem tenta suicídio uma vez, tentará } \\
\text { outras. }\end{array}$ \\
\hline $\mathbf{V}$ & $\mathrm{F}$ & 14. Quem se mata, provavelmente tentou mais de uma vez antes de conseguir. \\
\hline $\mathbf{V}$ & $\mathrm{F}$ & 15. Existem pessoas em risco que não podem ser deixadas sozinhas. \\
\hline $\mathbf{V}$ & $\mathrm{F}$ & $\begin{array}{l}\text { 16. Quem tem tentativas na família ou em pessoas significativas tem mais risco de } \\
\text { morrer por suicídio. }\end{array}$ \\
\hline $\mathbf{V}$ & $F$ & 17. Suicídio é um ato de coragem. \\
\hline $\mathbf{V}$ & $\mathrm{F}$ & 18. Suicídio é um ato de covardia. \\
\hline $\mathbf{V}$ & $\mathrm{F}$ & $\begin{array}{l}\text { 19. Se cometeu suicídio é porque a situação era tão ruim que provavelmente a } \\
\text { morte era a melhor saída. }\end{array}$ \\
\hline $\mathbf{V}$ & $\mathrm{F}$ & 20. Suicídio é uma tentativa de escapar de um sofrimento psíquico grave. \\
\hline $\mathbf{V}$ & $\mathrm{F}$ & 21. Quem tem raiva do suicida tem razão de lhe dar o troco \\
\hline $\mathbf{V}$ & $\mathrm{F}$ & $\begin{array}{l}\text { 22. Existem dois tipos de pacientes suicidas: os que manipulam e os que realmente } \\
\text { querem morrer. }\end{array}$ \\
\hline $\mathbf{V}$ & $\mathrm{F}$ & 23. Sugerir formas de se matar para um suicida não representa um perigo real. \\
\hline $\mathbf{V}$ & $\mathrm{F}$ & $\begin{array}{l}\text { 24. Os sentimentos mais comuns que amigos e pessoas da família têm em relação } \\
\text { ao suicida são raiva, culpa e medo. }\end{array}$ \\
\hline $\mathbf{V}$ & $\mathrm{F}$ & $\begin{array}{l}\text { 25. A decisão de tentar o suicídio é frequentemente impulsiva e, se a pessoa puder } \\
\text { deixar passar o desespero do momento, ela terá melhores chances de se } \\
\text { recuperar. }\end{array}$ \\
\hline $\mathbf{V}$ & $\mathrm{F}$ & 26. O desespero é um sentimento comum em quem faz uma tentativa de suicídio. \\
\hline $\mathbf{V}$ & $\mathrm{F}$ & $\begin{array}{l}\text { 27. Afetos intoleráveis, como culpa, humilhação (fracasso), ódio, sensação de } \\
\text { rejeição ou abandono fazem parte do quadro do paciente de risco de suicídio. }\end{array}$ \\
\hline
\end{tabular}




\begin{tabular}{|c|c|c|}
\hline $\mathbf{V}$ & $\mathrm{F}$ & $\begin{array}{l}\text { 28. O isolamento e problemas graves na rede social representam um perigo } \\
\text { especial para pessoas em risco de suicídio. }\end{array}$ \\
\hline $\mathbf{V}$ & $\mathrm{F}$ & 29. Só vai atrapalhar dar muita atenção a quem faz uma tentativa de suicídio. \\
\hline $\mathbf{V}$ & $\mathrm{F}$ & 30. Falar sobre suicídio com pessoas deprimidas pode estimulá-las a uma tentativa. \\
\hline $\mathbf{V}$ & $\mathrm{F}$ & $\begin{array}{l}\text { 31. Se ele está falando sobre suas ideias suicidas, isso quer dizer que ele está fora } \\
\text { de risco. }\end{array}$ \\
\hline $\mathbf{V}$ & $\mathrm{F}$ & $\begin{array}{l}\text { 32. Quem faz uma tentativa de suicídio para chamar atenção não merece crédito, } \\
\text { só vai reforçar o que ele fez. }\end{array}$ \\
\hline $\mathbf{V}$ & $\mathrm{F}$ & $\begin{array}{l}\text { 33. Se um paciente melhorou rapidamente, ele está fora de risco. Posso ficar } \\
\text { tranquilo. }\end{array}$ \\
\hline $\mathbf{V}$ & $\mathrm{F}$ & $\begin{array}{l}\text { 34. Quando a gente fala de suicídio, só estamos dando mais força para o } \\
\text { comportamento. }\end{array}$ \\
\hline $\mathbf{V}$ & $\mathrm{F}$ & 35. Quem faz uma tentativa de suicídio tem dificuldade de confiar. \\
\hline $\mathbf{V}$ & $\mathrm{F}$ & 36. É preciso ter calma e paciência para ajudar uma pessoa que fez uma tentativa. \\
\hline $\mathbf{V}$ & $\mathrm{F}$ & 37. Uma pessoa em risco, para confiar, precisa se sentir ouvida e respeitada. \\
\hline $\mathbf{V}$ & $\mathrm{F}$ & 38. Se eu der ouvidos a um suicida, ele pode se matar. \\
\hline $\mathbf{V}$ & F & 39. Só "loucos" cometem suicídio. \\
\hline $\mathbf{V}$ & $\mathrm{F}$ & 40. Um dia ruim pode levar alguém "normal" a cometer suicídio. \\
\hline $\mathbf{V}$ & $\mathrm{F}$ & 41. Quem não tem transtorno mental não se mata. \\
\hline $\mathbf{V}$ & $\mathrm{F}$ & $\begin{array}{l}\text { 42. Entre os casos de suicídio, a grande maioria (90 a 95\%) tinha um transtorno } \\
\text { mental diagnosticável. }\end{array}$ \\
\hline $\mathbf{V}$ & $\mathrm{F}$ & $\begin{array}{l}\text { 43. A depressão e o transtorno bipolar (mania) são os transtornos de mais riscos } \\
\text { para o suicídio. }\end{array}$ \\
\hline $\mathbf{V}$ & $\mathrm{F}$ & 44. Entre as pessoas depressivas, muitas estão em risco, mas poucas se matam. \\
\hline $\mathbf{V}$ & $\mathrm{F}$ & 45. A maioria das pessoas depressivas fazem tentativas de suicídio. \\
\hline $\mathbf{V}$ & $\mathrm{F}$ & 46. A depressão é um diagnóstico óbvio, fácil de ser percebido. \\
\hline $\mathbf{V}$ & $\mathrm{F}$ & $\begin{array}{l}\text { 47. Existem mais suicidas nas casas do que existem armas de fogo comparadas } \\
\text { com as casas que não têm. }\end{array}$ \\
\hline $\mathbf{V}$ & F & $\begin{array}{l}\text { 48. As pessoas que tentam suicídio apresentam uma história de eventos estressores } \\
\text { mais frequentes e severos que as não suicidas. }\end{array}$ \\
\hline $\mathbf{V}$ & $\mathrm{F}$ & $\begin{array}{l}\text { 49. Os grupos minoritários apresentam maiores taxas de suicídio (minorias sociais } \\
=\text { mulheres, negros, pessoas com deficiências físicas, etc.). }\end{array}$ \\
\hline $\mathbf{V}$ & $\mathrm{F}$ & $\begin{array}{l}\text { 50. As taxas de suicídio tendem a aumentar antes de feriados e das festas de fim de } \\
\text { ano. }\end{array}$ \\
\hline $\mathbf{V}$ & $\mathrm{F}$ & $\begin{array}{l}\text { 51. O suicídio é esperado em casos de privação severa, especialmente em casos de } \\
\text { pessoas com doenças terminais, como em casos de câncer ou de } \\
\text { soropositividade para o HIV. }\end{array}$ \\
\hline $\mathbf{V}$ & $\mathrm{F}$ & $\begin{array}{l}\text { 52. Conflitos, perdas e separações são os eventos que mais frequentemente } \\
\text { antecedem uma tentativa de suicídio. }\end{array}$ \\
\hline $\mathbf{V}$ & $\mathrm{F}$ & $\begin{array}{l}\text { 53. O desejo de morte ou comportamento de risco de suicídio geralmente é } \\
\text { resultado de um longo e silencioso processo de sofrimento, que poderia ter sido } \\
\text { relatado ou observado precocemente. }\end{array}$ \\
\hline $\mathbf{V}$ & $\mathrm{F}$ & 54. Quem tem tentativas na família tem mais risco de morrer por suicídio. \\
\hline $\mathbf{V}$ & $\mathrm{F}$ & $\begin{array}{l}\text { 55. Quem tem ideação ou outros comportamentos suicidas tem mais risco de } \\
\text { morrer por qualquer outra causa (por problemas de saúde, homicídio ou } \\
\text { acidentes). }\end{array}$ \\
\hline $\mathbf{V}$ & $\mathrm{F}$ & $\begin{array}{l}\text { 56. Os períodos mais críticos para uma pessoa de alto risco de suicídio ocorrem em } \\
\text { períodos de transição de tratamento (férias do terapeuta, encaminhamento, } \\
\text { transferência de terapeuta, transferência de serviços ou alta de internação). }\end{array}$ \\
\hline
\end{tabular}




\begin{tabular}{|c|c|c|c|}
\hline $\mathbf{V}$ & $\mathrm{F}$ & $\begin{array}{l}\text { 57. Uma situação crítica de alto risco para o suicídio envolve períodos de } \\
\text { dificuldades no tratamento, especialmente as dificuldades de formação ou } \\
\text { manutenção do vínculo terapêutico. }\end{array}$ \\
\hline $\mathbf{V}$ & $\mathrm{F}$ & $\begin{array}{l}\text { 58. Modificações no regime de medicações psiquiátricas geram períodos de risco } \\
\text { que requerem monitoramento constante, até mesmo diariamente. }\end{array}$ \\
\hline $\mathbf{V}$ & $\mathrm{F}$ & $\begin{array}{l}\text { 59. O acesso aos meios ou métodos de suicídio deve ser avaliado, suprimido e } \\
\text { monitorado em casos de risco. }\end{array}$ \\
\hline $\mathbf{V}$ & $\mathrm{F}$ & $\begin{array}{l}\text { 60. Uma nova tentativa de suicídio é mais provável no primeiro mês do que três } \\
\text { meses depois da última tentativa. }\end{array}$ \\
\hline V & $\mathrm{F}$ & $\begin{array}{l}\text { 61. É preciso ter sangue frio para trabalhar com um paciente suicida. } \\
\text { V }\end{array} \mathrm{F}$ & $\begin{array}{l}\text { 62. O paciente desesperançoso pode perceber a tentativa de levá-lo à oração ou a } \\
\text { outros comportamentos de religiosos como atos coercitivos que pioram sua } \\
\text { condição de risco. }\end{array}$ \\
\hline
\end{tabular}




\section{Anexo C - Dados sociodemográficos - Estudo 1}

1) Idade:

2) Sexo: ( 1) feminino (2) masculino

3) Você se considera de qual cor/raça?
( 1 ) Preta
( 2 ) Parda
( 3 ) Branca
( 4 ) Amarela
( 5 ) Indígena
( 6 ) Outra

4) Em que cidade você nasceu?

5) Religião:

( 1 ) Católica

( 2 ) Protestante

( 3 ) Outras

6) Dê uma nota de 1 a 10 para a importância que a religião tem em sua vida:

7) Estado Civil:

( 1 ) Casado

( 2 ) Solteiro

( 3 ) Divorciado

(4) Outros

8) Status do relacionamento

( 1 ) Sem relacionamento

( 2 ) Em relacionamento aberto

( 3 ) Em relacionamento sério

( 4 ) Em relacionamento complicado

9) Formação:

( 1 ) Ensino Médio

( 2 ) Superior incompleto

( 3 ) Superior

( 4 ) Pós-graduado

10) Se a opção for superior, qual o curso?

11) Em relação a sua vida profissional:

( 1 ) está trabalhando ou estagiando

( 2 ) já trabalhou (estagiou), mas atualmente não trabalha (estagia)

( 3 ) não trabalha e nem realiza estágio

( 4 ) nunca trabalhou

12) Cargo no local onde trabalha: 
Anexo D - Gabarito da EMCS, após análise fatorial, com 32 itens

Itens

Gabarito

1. O impulso suicida é agudo e passageiro.

2. A tentativa de suicídio representa uma vontade de aparecer, de chamar a atenção.

3. Via de regra, é mais seguro pensar que quem tenta suicídio uma vez, tentará outras.

4. A tentativa de suicídio é uma manipulação.

5. É preciso ter calma e paciência para ajudar uma pessoa que fez uma tentativa.

\section{V}

6. Uma vez suicida, a pessoa será sempre suicida.

7. A tendência suicida é hereditária, passa de geração em geração.

8. As pessoas que ameaçam, não se matam.

9. O desejo de morte ou comportamento de risco de suicídio geralmente é resultado de um longo e silencioso processo de sofrimento, que poderia ter sido relatado ou observado precocemente.

10. Quem realmente quer se matar, não avisa, se mata da primeira vez.

11. A tentativa de suicídio representa um pedido desesperado de ajuda.

12. Ele tomou só aspirina. Na verdade, não queria morrer.

13. Existem pessoas em risco que não podem ser deixadas sozinhas.

14. Suicídio é um ato de coragem.

15. Quem tem ideação ou outros comportamentos suicidas tem mais risco de morrer por qualquer outra causa (por problemas de saúde, homicídio ou acidentes).

16. Quem tem raiva do suicida tem razão de lhe dar o troco

17. Sugerir formas de se matar para um suicida não representa um perigo real.

18. O desespero é um sentimento comum em quem faz uma tentativa de suicídio.

19. Só vai atrapalhar dar muita atenção a quem faz uma tentativa de suicídio.

20. Falar sobre suicídio com pessoas deprimidas pode estimulá-las a uma tentativa.

21. Se ele está falando sobre suas ideias suicidas, isso quer dizer que ele está fora de risco.

22. Quem faz uma tentativa de suicídio para chamar a atenção não merece crédito, só vai reforçar o que ele fez.

23. Se um paciente melhorou rapidamente, ele está fora de risco. Posso ficar tranquilo.

24. Quando a gente fala de suicídio, só estamos dando mais força para o comportamento.

25. Uma pessoa em risco, para confiar, precisa se sentir ouvida e respeitada.

26. Se eu der ouvidos a um suicida, ele pode se matar.

V

28. A depressão é um diagnóstico óbvio, fácil de ser percebido.

$\mathrm{V}$

29. Quem não tem transtorno mental, não se mata. antecedem uma tentativa de suicídio.

31. Suicídio é um ato de covardia. 


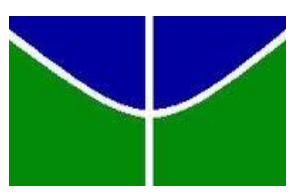

Anexo E - TCLE - Estudo 2

\section{Termo de Consentimento para Participação em Pesquisa}

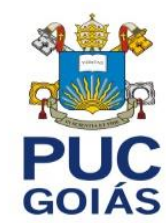

Convido você a participar da pesquisa "Mitos e Crenças sobre suicídio: visão dos profissionais de segurança". Esta pesquisa é de responsabilidade de Doutoranda Juliany Gonçalves Guimarães (PUC Goiás) e Dr. Marcelo Tavares, pesquisadores do Programa de Pós-Graduação em Psicologia Clínica e Cultura da Universidade de Brasília.

Este estudo tem como objetivo investigar como os profissionais que atendem emergências de suicídio entendem esse fenômeno e como lidam com ele no dia a dia de suas atividades. Conhecer melhor a prática de diversos serviços que tratam com pessoas com risco de suicídio ou com comportamentos suicidas é fundamental para orientar as instituições acerca do tipo de treinamento e suporte necessário para o exercício de cada profissão.

Caso concorde com sua participação, você será solicitado(a) a responder um questionário composto por questões objetivas. Você terá todas as instruções do preenchimento no cabeçalho de cada escala. Asseguramos que os dados serão analisados apenas em grupo e que seu nome ou seus resultados pessoais são sigilosos e não serão divulgados. Será mantido o mais rigoroso sigilo mediante a omissão total de informações que permitam identificá-lo(a).

Caso tenham qualquer dúvida em relação à nossa pesquisa, pode entrar em contato conosco através dos telefones indicados abaixo:

Juliany Guimarães

Profa. Puc Goias/Psicologia

Doutoranda PPG-PsiCC/IP/UNB

(62) $98138-0496$
Marcelo Tavares

Orientador PPG-PsiCC/IP/UNB

(61) 98111-1819

juliany.psi@pucgoias.edu.br 
Termo de Consentimento Livre, após Esclarecimento

Diante do exposto eu, declaro que estou ciente das informações recebidas e que concordo com a minha participação na pesquisa "Mitos e Crenças sobre suicídio: visão dos profissionais de segurança", descrita no verso da folha anterior. Atesto que tive a possibilidade de lê-lo e obter os esclarecimentos necessários. Estou ciente de que terei a oportunidade de entrar em contato com os pesquisadores posteriormente, em outro momento, caso eu sinta a necessidade de obter novos esclarecimentos a respeito desta pesquisa.

Goiânia, ___ de outubro de 2016.

Assinatura do Participante

Documento de Identidade

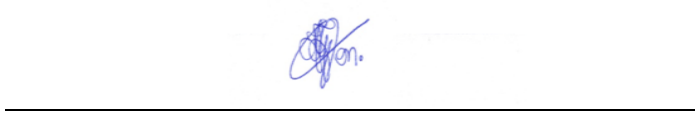

Assinatura do pesquisador

$1^{\text {a }}$ Via participante

$2^{\text {a }}$ Via pesquisador (devolver assinada, se concordar) 


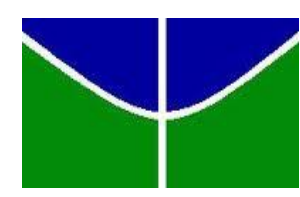

Instruções:

\section{Anexo F - Questionário de Pesquisa} Parte I - EMCS

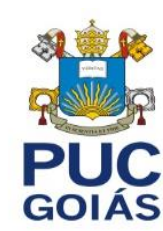

Este questionário é composto por quatro escalas, que objetivam investigar como os profissionais militares percebem o tema "suicídio". Para participar, basta escolher a resposta que melhor representa sua opinião.

Nos itens abaixo, marque $\mathbf{V}$ se achar a ideia do item verdadeira ou $\mathbf{F}$ se achar que o item expressa uma ideia falsa.

\begin{tabular}{|c|c|c|}
\hline Itens & $\mathbf{V}$ & $\mathbf{F}$ \\
\hline 1. O impulso suicida é agudo e passageiro. & $\mathrm{V}$ & $\bar{F}$ \\
\hline $\begin{array}{l}\text { 2. A tentativa de suicídio representa uma vontade de aparecer, de chamar a } \\
\text { atenção. }\end{array}$ & V & $\mathrm{F}$ \\
\hline $\begin{array}{l}\text { 3. Via de regra, é mais seguro pensar que quem tenta suicídio uma vez, } \\
\text { tentará outras. }\end{array}$ & V & $\mathrm{F}$ \\
\hline 4. A tentativa de suicídio é uma manipulação. & V & $\mathrm{F}$ \\
\hline $\begin{array}{l}\text { 5. É preciso ter calma e paciência para ajudar uma pessoa que fez uma } \\
\text { tentativa. }\end{array}$ & $\mathrm{V}$ & $\mathrm{F}$ \\
\hline 6. Uma vez suicida, a pessoa será sempre suicida. & V & $\mathrm{F}$ \\
\hline 7. A tendência suicida é hereditária, passa de geração a geração. & V & \\
\hline 8. As pessoas que ameaçam, não se matam. & $\mathrm{V}$ & $\mathrm{F}$ \\
\hline $\begin{array}{l}\text { 9. O desejo de morte ou comportamento de risco de suicídio geralmente é } \\
\text { resultado de um longo e silencioso processo de sofrimento, que poderia } \\
\text { ter sido relatado ou observado precocemente. }\end{array}$ & $\mathrm{V}$ & $\mathrm{F}$ \\
\hline 10. Quem realmente quer se matar, não avisa, se mata da primeira vez. & V & \\
\hline 11. A tentativa de suicídio representa um pedido desesperado de ajuda. & $\mathrm{V}$ & $\mathrm{F}$ \\
\hline 12. Ele tomou só aspirina. Na verdade, não queria morrer. & V & $\mathrm{F}$ \\
\hline 13. Existem pessoas em risco que não podem ser deixadas sozinhas. & $\mathrm{V}$ & $\mathrm{F}$ \\
\hline 14. Suicídio é um ato de coragem. & V & $\mathrm{F}$ \\
\hline $\begin{array}{l}\text { 15. Quem tem ideação ou outros comportamentos suicidas tem mais risco de } \\
\text { morrer por qualquer outra causa (por problemas de saúde, homicídio ou } \\
\text { acidentes). }\end{array}$ & $\mathrm{V}$ & $\mathrm{F}$ \\
\hline 16. Quem tem raiva do suicida tem razão de lhe dar o troco & V & $\mathrm{F}$ \\
\hline $\begin{array}{l}\text { 17. Sugerir formas de se matar para um suicida não representa um perigo } \\
\text { real. }\end{array}$ & V & \\
\hline $\begin{array}{l}\text { 18. O desespero é um sentimento comum em quem faz uma tentativa de } \\
\text { suicídio. }\end{array}$ & $\mathrm{V}$ & $\mathrm{F}$ \\
\hline 19. Só vai atrapalhar dar muita atenção a quem faz uma tentativa de suicídio. & V & $\mathrm{F}$ \\
\hline $\begin{array}{l}\text { 20. Falar sobre suicídio com pessoas deprimidas pode estimulá-las a uma } \\
\text { tentativa. }\end{array}$ & $\mathrm{V}$ & \\
\hline $\begin{array}{l}\text { 21. Se ele está falando sobre suas ideias suicidas, isso quer dizer que ele está } \\
\text { fora de risco. }\end{array}$ & V & $\mathrm{F}$ \\
\hline $\begin{array}{l}\text { 22. Quem faz uma tentativa de suicídio para chamar atenção não merece } \\
\text { crédito, só vai reforçar o que ele fez. }\end{array}$ & V & $\mathrm{F}$ \\
\hline $\begin{array}{l}\text { 23. Se um paciente melhorou rapidamente, ele está fora de risco. Posso ficar } \\
\text { tranquilo. }\end{array}$ & $\mathrm{V}$ & $\mathrm{F}$ \\
\hline $\begin{array}{l}\text { 24. Quando a gente fala de suicídio, só estamos dando mais força para o } \\
\text { comportamento. }\end{array}$ & $\mathrm{V}$ & $\mathrm{F}$ \\
\hline
\end{tabular}


25. Uma pessoa em risco, para confiar, precisa se sentir ouvida e respeitada.

26. Se eu der ouvidos a um suicida, ele pode se matar.

27. Só "loucos" cometem suicídio.

28. A depressão é um diagnóstico óbvio, fácil de ser percebido.

29. Quem não tem transtorno mental não se mata.

30. Conflitos, perdas e separações são os eventos que mais frequentemente antecedem uma tentativa de suicídio.

31. Suicídio é um ato de covardia. $\quad$ V F

32. É preciso ter sangue frio para trabalhar com um paciente suicida.

\section{Parte II. Questionário de Valores Psicossociais (QVP-24)}

Instruções:

Logo abaixo você encontrará uma lista contendo um conjunto de valores sociais aos quais deve atribuir uma nota variando de 0 (zero) a 10 (dez), considerando o grau de importância de cada um dos valores para a construção de uma sociedade ideal para se viver. Lembre-se de que quanto menor a nota, menor será a importância do valor e, quanto maior for a nota, maior será a importância do valor.

Nota:

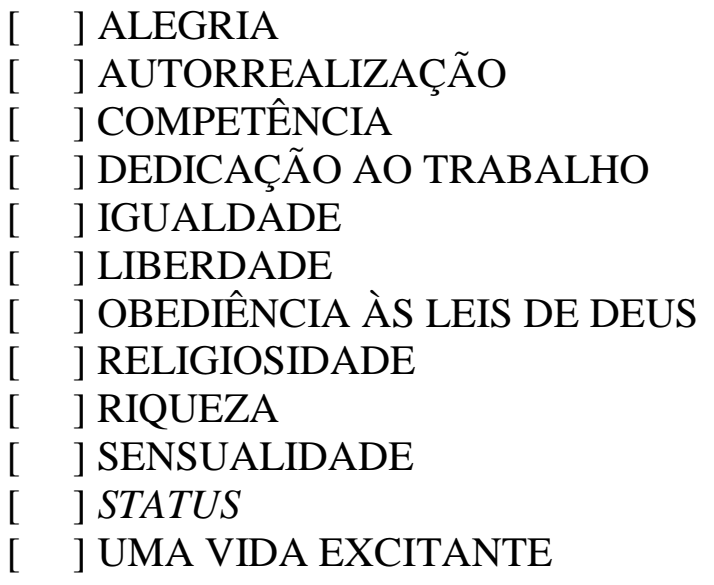

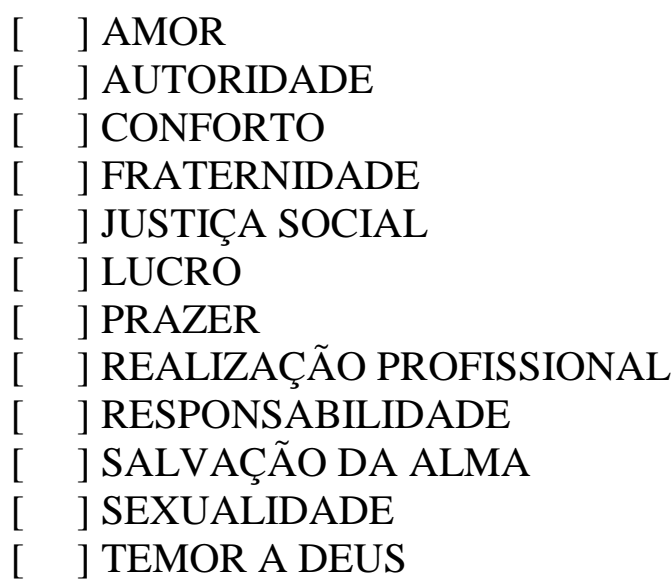

\section{Parte III. Escala de Valores Organizacionais}

Neste questionário, você deve perguntar a si próprio: "Que valores são importantes para a instituição (CBM ou PM) em que trabalho?". Entende-se por valores organizacionais os princípios que orientam a vida nas organizações.

$\mathrm{Na}$ página a seguir há uma lista de valores. Esses valores foram levantados em diferentes organizações. Entre os parênteses que seguem cada valor encontra-se uma explicação que pode ajudá-lo(a) a compreender o seu significado.

Sua tarefa é avaliar quão importante é para sua instituição cada valor, como um princípio orientador na vida da instituição.

Observe bem que não se trata de avaliar os seus valores pessoais, nem os valores que você gostaria que existissem na sua instituição, mas sim os valores que, segundo você, orientam a vida de sua instituição.

Avalie a importância dos valores da sua organização em uma escala de 1 a 7. 
A escala encontra-se abaixo.

Como princípio orientador na vida da minha organização, este valor é:

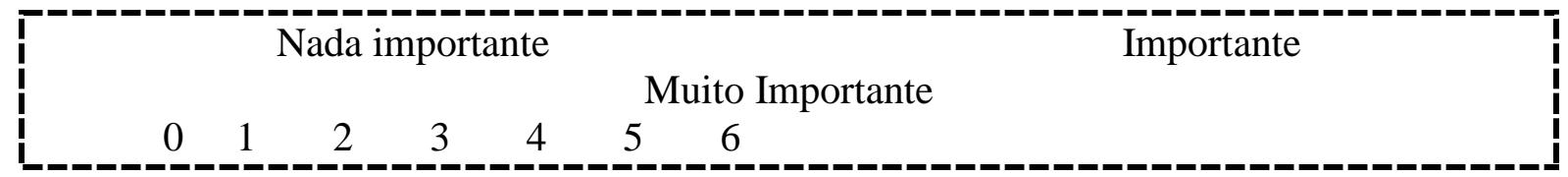

0 = significa que o valor é nada importante; não é relevante como um princípio orientador na vida de sua organização.

3 = significa que o valor é importante.

$6=$ significa que o valor é muito importante.

Quanto maior o número $(0,1,2,3,4,5,6)$, mais importante é o valor como um princípio orientador na vida da sua organização.

Além dos números de 0 a 6 , em suas avaliações você pode usar ainda os números 1 e 7 , considerando que:

-1 = significa que o valor é oposto aos princípios que orientam a vida na sua organização.

7 = significa que o valor é de suprema importância como um princípio orientador na vida da sua organização. Geralmente, uma organização não possui mais de dois desses valores.

Como um principio orientador na vida da minha organização, esse valor é:

Oposto aos princípios
$\begin{aligned} & \text { Nada importante } \\ & \text { Importante }\end{aligned}$

No espaço antes de cada valor escreva o número $(-1,0,1,2,3,4,5,6,7)$ que corresponde à avaliação que você faz deste valor, conforme os critérios acima definidos. Tente diferenciar, tanto quanto possível, os valores entre si, usando para isso todos os números. Evidentemente, você poderá repetir os números em suas respostas/avaliações.

Antes de começar, leia os valores de 1 a 32, escolha aquele que, segundo você, é o valor supremo para sua organização e avalie-o com 7. A seguir, identifique o(s) valor(es) oposto(s) aos valores de sua organização e avalie-os como -1. Se não houver valor algum deste tipo, escolha aquele que tem menos importância para sua organização e o avalie como 0 ou 1, de acordo com sua importância. Depois, avalie os demais valores (até o 38).

\section{Lista de Valores Organizacionais}

Lembre-se que não se trata de avaliar os seus valores pessoais, nem os valores que você gostaria que existissem na organização, mas sim os valores que, segundo você, orientam a vida de sua organização. 


\begin{tabular}{|c|c|}
\hline Nota & Valores \\
\hline & 1. Abertura (promoção de um clima propício às sugestões e ao diálogo) \\
\hline & 2. Amizade (clima de relacionamento amistoso entre os militares) \\
\hline & 3. Benefícios (promoção de programas assistenciais aos militares) \\
\hline & 4. Coleguismo (clima de compreensão e apoio aos/entre os militares) \\
\hline & 5. Competência (saber executar as tarefas da organização) \\
\hline & 6. Competitividade (conquistar a população em relação a outras instituições) \\
\hline & 7. Comprometimento (identificação com a missão da instituição) \\
\hline & 8. Cooperação (clima de ajuda mútua) \\
\hline & 9. Criatividade (capacidade de inovar a instituição) \\
\hline & 10. Dedicação (promoção ao trabalho com afinco) \\
\hline & $\begin{array}{l}\text { 11. Democracia (participação de todos os militares envolvidos nos processos } \\
\text { decisórios) }\end{array}$ \\
\hline & 12. Eficácia (fazer as tarefas de forma a atingir os objetivos esperados) \\
\hline & 13. Eficiência (executar as tarefas da instituição de forma certa) \\
\hline & 14. Fiscalização (controle do serviço executado) \\
\hline & 15. Flexibilidade (administração que se adapta as situações concretas) \\
\hline & 16. Harmonia (ambiente de relacionamento interpessoal adequado) \\
\hline & 17. Hierarquia (respeito aos níveis de autoridade) \\
\hline & 18. Honestidade (promoção de combate à corrupção na instituição) \\
\hline & $\begin{array}{l}\text { 19. Incentivo à pesquisa (incentivo à pesquisa relacionada com interesses da } \\
\text { organização) }\end{array}$ \\
\hline & 20. Integração interorganizacional (intercâmbio com outras instituições) \\
\hline & 21. Justiça (imparcialidade nas decisões administrativas) \\
\hline & $\begin{array}{l}\text { 22. Modernização de recursos materiais (preocupação em investir na aquisição } \\
\text { de equipamentos, programas de informática e outros) }\end{array}$ \\
\hline & 23. Obediência (tradição e respeito às ordens) \\
\hline & 24. Organização (existência de normas claras e explícitas) \\
\hline & 25. Planejamento (elaboração de planos para evitar improvisação na organização) \\
\hline & 26. Plano de Carreira (preocupação com a carreira funcional dos militares) \\
\hline & 27. Polidez (clima de cortesia e educação no relacionamento cotidiano) \\
\hline & 28. Pontualidade (preocupação com o cumprimento de horários e compromissos) \\
\hline & $\begin{array}{l}\text { 29. Postura profissional (promover a execução das funções ocupacionais de } \\
\text { acordo com as normas da organização) }\end{array}$ \\
\hline & 30. Probidade (administrar de maneira adequada o dinheiro público) \\
\hline & 31. Produtividade (atenção voltada para a produção e a prestação de serviços) \\
\hline & 32. Qualidade (compromisso com o aprimoramento dos produtos e serviços) \\
\hline & $\begin{array}{l}\text { 33. Qualificação de recursos humanos (promover a capacitação e o treinamento } \\
\text { do efetivo) }\end{array}$ \\
\hline & 34. Reconhecimento (reconhecimento do mérito na realização do trabalho) \\
\hline & 35. Respeito (consideração às pessoas e opiniões) \\
\hline & 36. Sociabilidade (estímulo às atividades sociais fora do ambiente de trabalho) \\
\hline & 37. Supervisão (acompanhamento e avaliação contínuos da tarefa) \\
\hline & 38. Tradição (preservar usos e costumes da organização) \\
\hline
\end{tabular}


Parte IV - Questionário sociodemográfico e questões sobre o atendimento em TAE

1. Idade:

2. Sexo: ( 1) feminino ( 2 ) masculino

3. Religião:
( 1 ) Católica
( 2 ) Evangélica
( 3 ) Espírita
( 4 ) Outras

4. Dê uma nota de 1 a 10 para a importância que a religião tem em sua vida:

5. Estado Civil:
( 1 ) Casado
( 2 ) Solteiro
( 3 ) Divorciado
( 4 ) Outros

6. Status do Relacionamento
( 1 ) Sem relacionamento
( 2 ) Em relacionamento aberto
( 3 ) Em relacionamento sério
( 4 ) Em relacionamento complicado

7. Formação:
( 1 ) Ensino Médio
(2) Superior incompleto
( 3 ) Superior
( 4 ) Pós-graduado

8. Se tiver ensino superior, qual o curso?

9. Cargo no local onde trabalha:

10. Ao longo de sua trajetória profissional, já atendeu ocorrência(s) de suicídio?
( ) Não
( ) Sim. Quantas vezes, aproximadamente?

11. Se respondeu afirmativamente: aponte brevemente o que acha mais difícil no atendimento a pessoas em tentativa de autoextermínio:

12. Com base em sua experiência e vivência, o que facilita ou torna mais fácil o atendimento a pessoas em tentativa de autoextermínio? 
Anexo G - Autorizações de Pesquisa

Platoforma MINISTÉRIO DA SAÚDE - Conselho Nacional de Saúde - Comissão Nacional de Ética em Pesquisa - CONEP Brasil

FOLHA DE ROSTO PARA PESQUISA ENVOLVENDO SERES HUMANOS

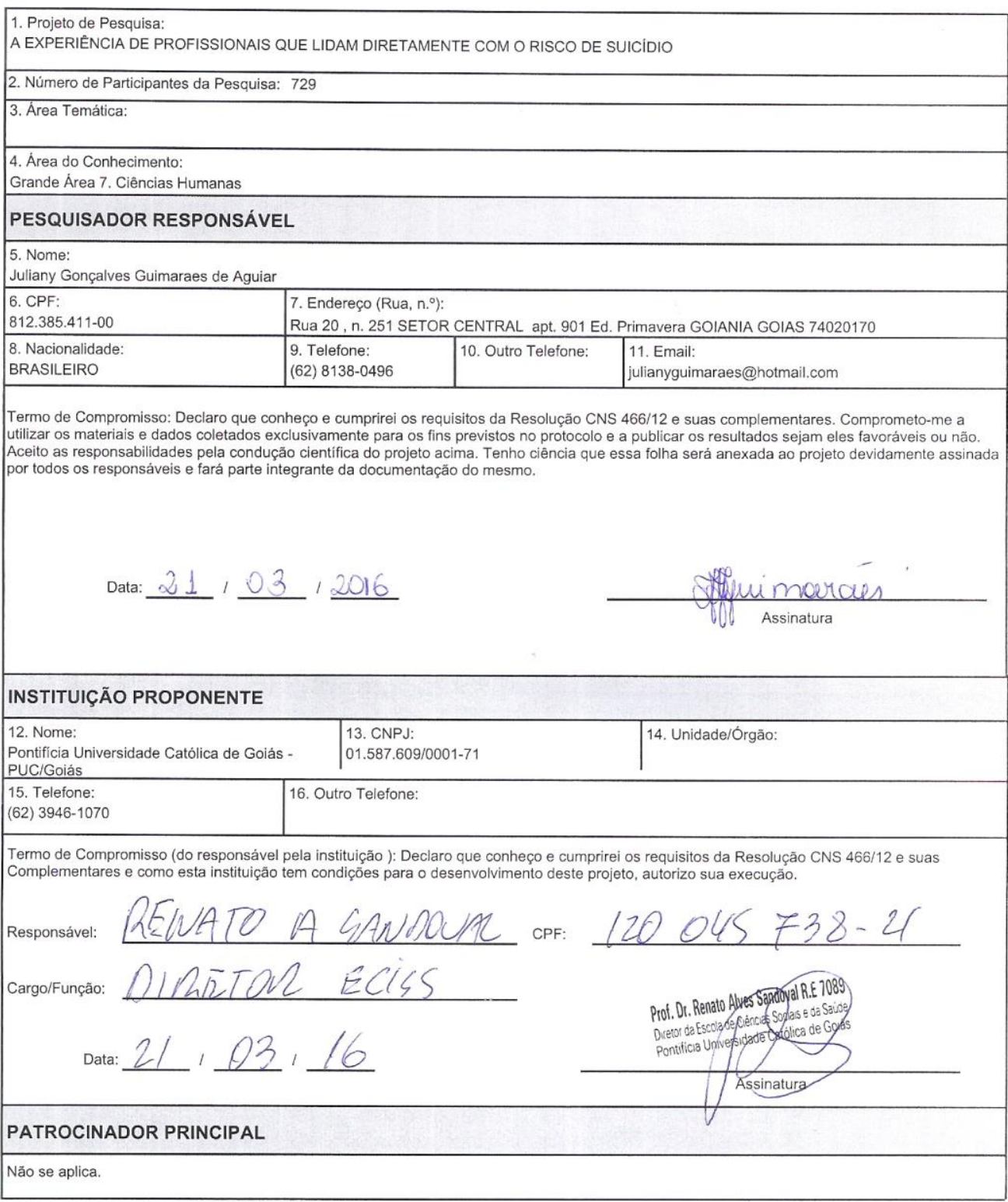


SECRETARIA DE ESTADO DA SEGURANÇA PÚBLICA CORPO DE BOMBEIROS MILITAR

COMANDO GERAL

À Senhora

Juliany Gonçalves Guimarães

Professora de Psicologia da Pontificia Universidade Católica de Goiás

Avenida Universitária, 1069, Setor Universitário

Goiânia - GO

Assunto: Pesquisa com bombeiros militares.

Senhora Professora,

Em atenção ao que consta no expediente encaminhado a essa Corporação em 15 de setembro último, que solicita autorização para realizar pesquisa com bombeiros militares que atuam na área de resgate pré-hospitalar, informamos a Vossa Senhoria que somos de parecer favorável à disponibilização de dados acerca do pleito.

No ensejo, colocamo-nos à disposição por meio do Coronel Leônidas Eduardo Dias, Comandante de Ensino Bombeiro Militar, para repassar demais informaçōes - ensino@bombeiros.go.gov.br, telefone 62-3201-2193.

Atenciosamente,

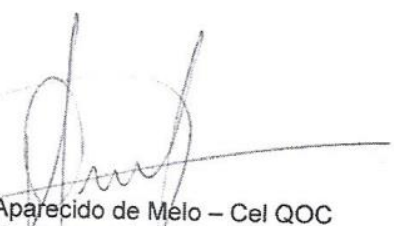

Divino Aparecido de Melo - Cel QOC Subcomandante Geral

Avenida Anhanguera 7304 


\section{GOIA}

\section{PRÓ-REITORIA DE PÓS-GRADUAÇÃO EM PESQUISA \\ PONTIFÍCIA UNIVERSIDADE CATÓLICA DE GOIÁS \\ COMITÉ DE ÉTICA EM PESQUISA - CEP \\ DECLARAÇÃO DE INSTITUIÇÃO COPARTICIPANTE}

Declaro ter lido e concordar com o projeto de pesquisa "Suicídio: "mitos e crenças" em grupos de atendimento (PM e BM) e profissionais de saúde. (nome do projeto) de responsabilidade do pesquisador Juliany Gonçaves Guimarães de Aguiar e declaro conhecer e cumprir as Resoluções Éticas Brasileiras, em especial a Resolução CNS 466/12. Esta instituição está ciente de suas corresponsabilidades como Instituição Coparticipante do presente projeto de pesquisa, e de seu compromisso no resguardo da segurança e bemestar dos sujeitos de pesquisa nela recrutados, dispondo de infraestrutura necessária para a garantia de tal segurança e bem estar. Estou ciente que a execução deste projeto dependerá da aprovação do mesmo pelo CEP da instituição proponente, mediante parecer ético consubstanciado e declaração de aprovação.

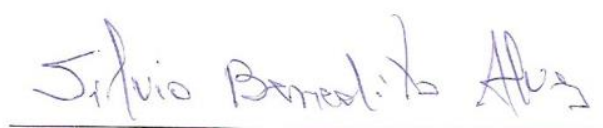

(Nome e função do responsável institucional) "Assinatura e carimbo do responsável institucional"

Sikvio Benedit to Alves - Coronel QOPM Comandante Gerai da PNGO 